\title{
Patagonia-Antarctica Early Paleozoic conjugate margins: Cambrian synsedimentary silicic magmatism, U-Pb dating of K-bentonites, and related volcanogenic rocks is
}

\author{
Pablo D. González ${ }^{\mathrm{a}, *}$, Ana M. Sato ${ }^{\mathrm{b}}$, Maximiliano Naipauer ${ }^{\mathrm{c}}$, Ricardo Varela ${ }^{\mathrm{b}}$, Miguel Basei ${ }^{\mathrm{d}}$, Kei Sato ${ }^{\mathrm{d}}$, \\ Eduardo J. Llambías ${ }^{\mathrm{b}, 1}$, Farid Chemale ${ }^{\mathrm{e}}$, Antonio Castro Dorado ${ }^{\mathrm{f}}$ \\ a Instituto de Investigación en Paleobiología y Geología, UNRN-CONICET, Av. Julio A. Roca 1242, R 8332 EXZ, General Roca, Río Negro, Argentina

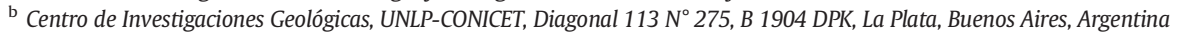 \\ c Instituto de Estudios Andinos “Don Pablo Groeber”, UBA-CONICET, Güiraldes 2160, Ciudad Universitaria, Pabellón II, C 1428 EHA, Buenos Aires, Argentina \\ ' Centro de Pesquisas Geocronológicas, Instituto de Geociências, USP, Rua do Lago 562, CEP 05508-080 São Paulo, SP, Brazil \\ e GEO-Departamento de Geologia Geral e Aplicada, Instituto de Geociências, Universidade de Brasília, ICC-Centro, Campus Universitário Darcy Ribeiro Asa Norte, CEP 70910-900, Brazil \\ ${ }^{\mathrm{f}}$ Departamento de Geología, Universidad de Huelva, Campus del Carmen, 21071 Huelva, Spain
}

\section{A R T I C L E I N F O}

\section{Article history:}

Received 23 February 2018

Received in revised form 29 May 2018

Accepted 29 May 2018

Available online 20 July 2018

Handling Editor: J.G. Meert

\section{Keywords:}

K-bentonite

U-Pb dating

Cambrian magmatism

Patagonia

Antarctica

Gondwana

\begin{abstract}
A B S T R A C T
This study describes the stratigraphic features, petrology and geochemistry and geochronology constraints of Kbentonites, ignimbrites and related volcanogenic rocks interbedded in the marine sedimentary sequence of the El Jagüelito Formation from northern Patagonia basement, southwestern Gondwana margin $\left(41^{\circ} 33^{\prime} \mathrm{S}-65^{\circ} 15^{\prime} \mathrm{W}\right.$, South America). Six SHRIMP and ICP-MS U-Pb zircon ages from pyroclastic and volcanogenic sedimentary rocks indicate two stages of synsedimentary volcanism at c. 530 and c. 515 Ma which constraint the whole volcano-sedimentary pile to Early-Middle Cambrian. Distal volcanic ash fall deposits of K-bentonites and proximal pyroclastic flows of ignimbrites were erupted from three subaerial to subaqueous eruptive centers and are associated with volcanogenic facies and sub-volcanic intrusive equivalents. The volcanic rocks were deposited synchronously with on-going dynamic siliciclastic sedimentation into an actively subsiding basin.

Dacitic K-bentonites and high-silica rhyolitic ignimbrites belong to the same high-K calc-alkaline/shoshonitic magma series and have a similar peraluminous signature. Their HFSE patterns with relative depletion in $\mathrm{Nb}, \mathrm{Sr}$ $\mathrm{P}$, and Ti and the LREE-enriched patterns with a negative Eu anomaly indicate characteristics of subductionrelated magmas associated with active continental arc magmatism. The geochemical discrimination diagrams together with geological features suggest an extensional tectonic setting for K-rich magmas within the overall convergent-margin system. Silicic, more potassic magmas with the inherited subduction-related character of the El Jagüelito Formation erupted on a back-arc basin. Their volcanic rocks are products of a mixture of fractionated mafic magmas and partial crustal melts. The integration of the Cambrian synsedimentary explosive volcanism of the El Jagüelito Formation with coeval magmatism of northern Patagonia led the interpretation to the continental scale of the paleo-Pacific margin of Gondwana by Early Paleozoic. The El Jagüelito Formation has provided consistent lithological, stratigraphic, geochemical and geochronological arguments to assess continental comparisons and a paleogeographic reconstruction between the eastern North Patagonian Massif and East Antarctica that fit in well the hypothesis that the northern Patagonia basement once occupied a position adjacent to East Antarctica. A series of geodynamic stages is proposed that allow for providing a Cambrian framework for understanding the magmatic arc-back arc system modified by episodic pulses of extension associated with slabroll back which terminated in detachment of northern Patagonia from the East Antarctica continental margin by Late Cambrian. The several lines of geological evidence discussed in this paper point to a parautochthonous origin of the eastern North Patagonian Massif as an outboard assemblage that represents the conjugate margin of the Pensacola-Queen Maud-Ellsworth-Whitmore Mountains of Antarctica.
\end{abstract}

(c) 2018 International Association for Gondwana Research. Published by Elsevier B.V. All rights reserved.

\footnotetext{
is In memory of Eduardo J. Llambias.

* Corresponding author at: Instituto de Investigación en Paleobiología y Geología, Universidad Nacional de Río Negro-CONICET, Av. Julio A. Roca 1242, R 8332 EXZ, General Roca, Río Negro, Argentina.

E-mail addresses: pdgonzalez@unrn.edu.ar (P.D. González), sato@cig.museo.unlp.edu.ar (A.M. Sato), maxinaipauer@gl.fcen.uba.ar (M. Naipauer), ricardovarela4747@gmail.com (R. Varela), baseimas@usp.br ksato@usp.br (M. Basei), llambias@cig.museo.unlp.edu.ar (E.J. Llambías), fchemale@unb.br (F. Chemale), dorado@uhu.es (A.C. Dorado).

1 Deceased.
} 


\section{Introduction}

The assembly of Gondwana supercontinent was mostly complete by the Early Paleozoic through the closure of oceans and development of orogenic belts, such as the Mozambique, Brasiliano-Pampeano, Pan African and Kuunga belts (e.g. Meert, 2003; Veevers, 2004; Jacobs and Thomas, 2004; Collins and Pisarevsky, 2005; Trindade et al., 2006; Meert and Liberman, 2008; Tohver et al., 2012, among others). The Terra Australis orogenic belt subsequently formed by convergent plate interactions extends along the Pacific-lapetus margin of East and West Gondwana between Australia and South America (Cawood, 2005). Continental margin sequences occur along the East and West Gondwana segments of the orogen, outboard of which lie a series of parautochthonous and allochthonous terrains. In southern South America, at the tip of Andean segment of the Terra Australis orogen, accretion of allochthonous terrane may have continued through Ordovician (Cuyania terrane, Ramos et al., 1998; Ramos, 2004), Devonian
(Chilenia terrane, Ramos et al., 1986) and even late Paleozoic times (Patagonia terrane, Ramos, 1984, 2008; von Gosen, 2002; Ramos et al., 2004; Fig. 1 A). Although geological, structural and magmatic evidence point to a Late Paleozoic time of Patagonia accretion to South America, Paleozoic paleomagnetic poles suggest that Patagonia did not undergo significant displacements relative to South America since Devonian times (Rapalini, 1998), and thus their collision against the southwestern Gondwana margin should have occurred in pre-Devonian times.

The possible allochthoneity of Patagonia has been the subject of more than three decades of discussion following the early proposal of "Patagonia terrane" made by Ramos (1984). Structural, geochronological and geophysical studies, as well as geodynamic analyses and paleogeographic reconstructions, have contributed to the issues of autochthonous or allochthonous, and even parautochthonous origin of Patagonia. Relevant hypotheses considered elsewhere are: (1) the entire Patagonia as autochthonous to Western Gondwana throughout the Paleozoic (Forsythe, 1982; Dalla Salda et al., 1992; Pankhurst et al.,

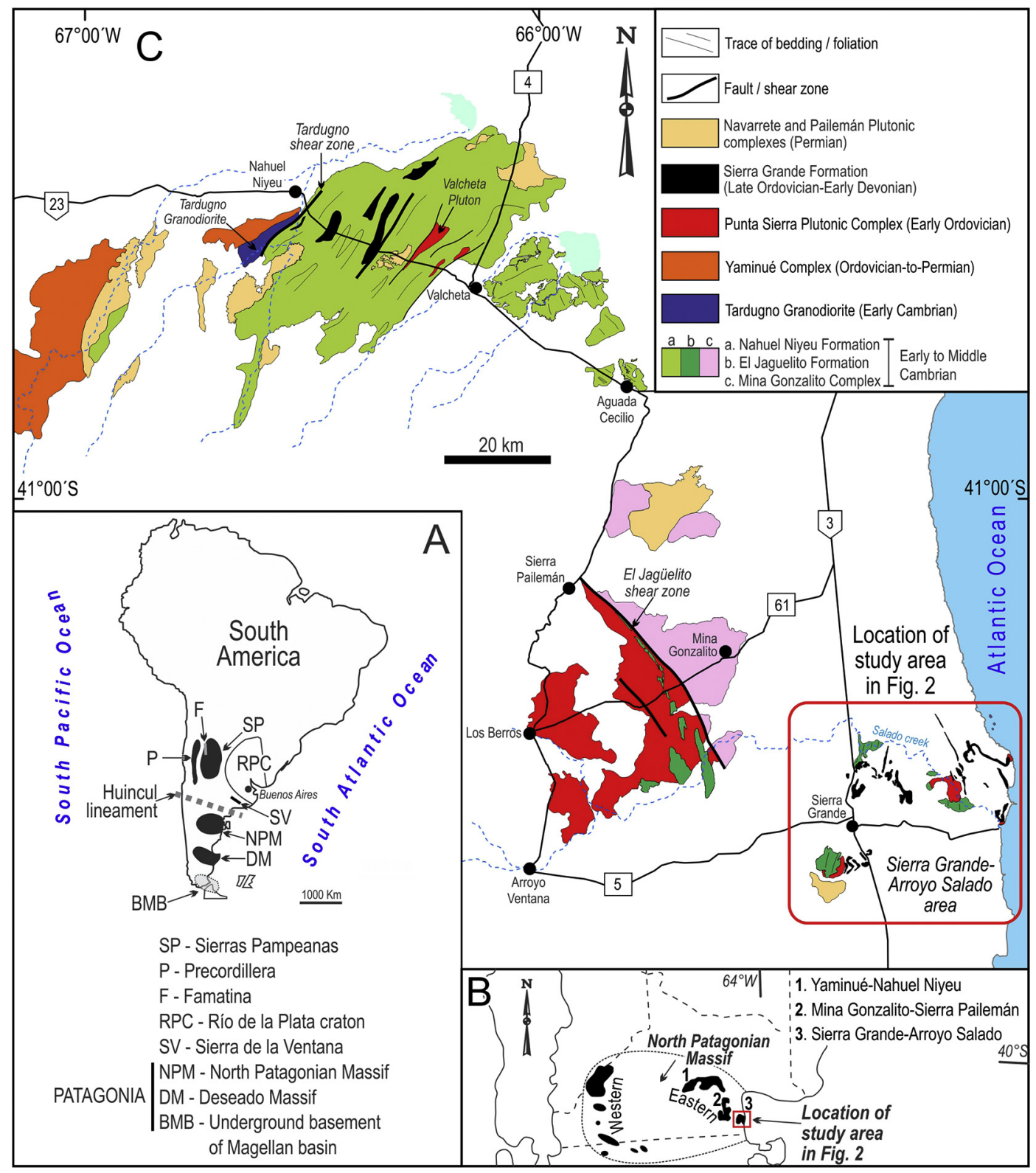

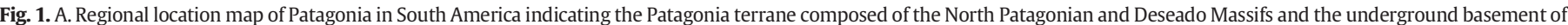

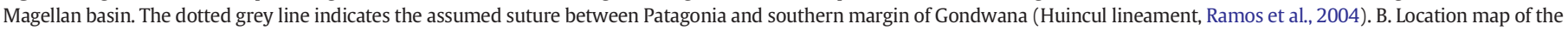

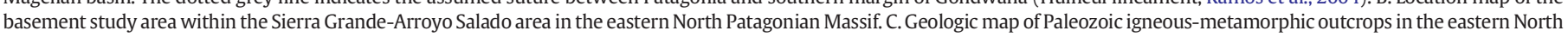
Patagonian Massif. The Yaminue-Nahuel Niyeu, Mina Gonzalito-Sierra Paileman, and Sierra Grande-Arroyo Salado areas are depicted. 
2003, 2014; Rapalini et al., 2013; Greco et al., 2017), (2) Cambrian rifting of the Deseado Massif, and collision at a similar position in the Late Paleozoic (Pankhurst et al., 2006), (3) two subductions with partly coeval collisions of parautochthonous Patagonia with the Antarctic Peninsula and both with Gondwana in the Late Paleozoic (Ramos, 2008; Castillo et al., 2017), (4) parautochthonous North Patagonian Massif, first rifted from Gondwana in Early to Middle Paleozoic, and then frontally collided in Late Paleozoic (Rapalini et al., 2010; López de Luchi et al., 2010; Martínez Dopico et al., 2011), (5) oblique Late Paleozoic subduction, resulting in indentation and escape tectonics in Northern Patagonia (Gregori et al., 2008), an interpretation that might be conciliated partly with the suggestion of Patagonia as a displaced terrane originating in a hypothetical platform developed between South America, Africa and Antarctica (Huber-Grünberg, 1990; Aceñolaza et al., 2002), and (6) the eastern North Patagonian Massif as the conjugate margin of the Pensacola Mountains in East Antarctica (Ramos and Naipauer, 2014). A common underlying idea in most of these models seems to be that Patagonia was not entirely an exotic terrane to southwestern Gondwana in Early Paleozoic times, as suggested by similar detrital zircon patterns of metasediments, lithological and geochronological correlations (González et al., 2002, 2010; Rapalini et al., 2013; Pankhurst et al., 2014; Greco et al., 2017), and recognition of the Cambrian and Ordovician magmatic arcs with similar $\mathrm{T}_{\mathrm{DM}}$ model ages which might represent the southern extension of the Pampean and Famatinian orogenic belts of the Sierras Pampeanas respectively (Dalla Salda et al., 1992; Pankhurst et al., 2006, 2014; García et al., 2014, 2015; Greco et al., 2017; Fig. 1 A). However, considering the above available data, the original position of Patagonia in Early Paleozoic paleogeography of the Southwestern Gondwana continent has remained to be elucidated.

The first documented finding of archeocyath fossils in South America within the northern Patagonia basement belonging to the El Jagüelito Formation opened new insights into the origin and paleogeography of Patagonia within the context of Gondwana assembly in Early Paleozoic (González et al., 2011a). With restricted paleogeographic distributions and limited age (exclusively Cambrian), archeocyath fossils are robust provenance markers (Hill, 1972; Rozanov and Debrenne, 1974; James and Debrenne, 1981; Debrenne and Kruse, 1989; Stone and Thomson, 2005; Debrenne, 2007). The Australia-Antarctica affinity and Early Cambrian age of the seven taxa recovered from limestone blocks belonging to a metaconglomerate layer of the El Jagüelito Formation (sample AB282, Figs. 2, 3) strongly suggests the possibility that Northern Patagonia may have originated close to the Transantarctic Mountains (AntarcticAustralian segment of the Terra Australis orogen) of southern East Gondwana (González et al., 2011a, 2011b; Naipauer et al., 2011), and therefore Patagonia would have been transferred from East to West Gondwana, an interpretation that might be conciliated with eastern North Patagonian Massif as the conjugate margin of the Pensacola Mountains in East Antarctica (Ramos and Naipauer, 2014).

In the North Patagonian Massif, in the Sierra Grande-Arroyo Salado area (Fig. 1 B), field mapping has revealed a number of pyroclastic deposits, including K-bentonite and ignimbrite beds, volcanic lava flows and sub-volcanic domes intercalated in the (low-grade meta-) sedimentary basement rocks of the El Jagüelito Formation, also containing the archeocyathan conglomerate layer. K-bentonites were derived from altered volcanic ash fall deposits which in turn are associated with silicic explosive volcanic eruptions. Volcanic ash clouds are well known to travel great distances, even across continents, and can thus help to link not only volcanic zones but also to bind stratigraphic provinces together internally, and with each other (Huff et al., 1999; Huff, 2008). In this regard, K-bentonites are useful as marker horizons for stratigraphic correlation and for interpreting the magma source and the geodynamic setting of volcanic arc from which they derive (Marker, 2005; Huff, 2016). Furthermore, the occurrence of Kbentonites in stratigraphic successions provides a powerful tool for dating such deposits, considering the deposition of the volcanic ejecta as instantaneous on a geological timescale and thus contemporaneous with siliciclastic sedimentation (Bowring and Schmitz, 2003). Thereby, findings of K-bentonite beds in the eastern North Patagonian Massif are a key geochronological feature, and then the dating of these $\mathrm{K}$ bentonites is a crucial issue regarding magmatic crystallization ages and thus allowing a better constraint for the timing of coeval sedimentation. Additionally, K-bentonites and related volcanic and pyroclastic rocks are good guide horizons for comparison with other Early Paleozoic basement rocks within Patagonia and elsewhere along the paleo-Pacific margin of Gondwana. Thus, K-bentonite beds from Patagonia are clues to contribute to the knowledge of Early Paleozoic explosive volcanism which has a continental distribution along the Terra Australis orogen of southwestern margin of Gondwana (Münker and Crawford, 2000; Cawood, 2005; Pankhurst et al., 2006, 2014; Greco et al., 2015).

This contribution describes the primary stratigraphic features, petrography, and geochemical affinity of the K-bentonites and associated volcano-pyroclastic rocks recorded in the El Jagüelito Formation from five outcrops in the Sierra Grande-Arroyo Salado area (eastern North Patagonian Massif, $41^{\circ} 33^{\prime} \mathrm{S}-65^{\circ} 15^{\prime} \mathrm{W}$, South America, Fig. 1 B, C). These results, together with six SHRIMP and ICP-MS U-Pb ages from igneous and sedimentary volcanogenic rocks provide insight into the temporal evolution of the volcano-sedimentary succession. We also analyze the volcano-sedimentary environments, volcanic facies, eruptive centers, and type of basin associated to deposition of the El Jagüelito Formation, and integrating all data within the regional context of the Early Paleozoic geodynamic scenario for the eastern North Patagonian basement.

Finally, we attempt a comprehensive lithologic, tectonostratigraphy, geochemical, and U-Pb geochronologic comparison and correlation between eastern North Patagonian basement units and several Cambrian units in East Antarctica, in order to assess the tectonic hypothesis of Ramos and Naipauer (2014) in which the eastern North Patagonian Massif was the conjugate margin of the Pensacola Mountains of Antarctica by the Early Paleozoic. A paleogeographic scenario is also discussed given K-bentonites and related volcano-pyroclastic rocks that have continental distribution in volcano-sedimentary sequences along the southwestern Gondwana margin.

\section{Regional geologic setting}

The extra-Andean Patagonia region south of $39^{\circ} \mathrm{S}$ includes three Paleozoic blocks with Cambro-Ordovician igneous-metamorphic basement rocks which, from north to south, are the North Patagonian and Deseado Massifs and the underground of the Magellan Basin (Fig. $1 \mathrm{~A}$ ).

In the eastern North Patagonian Massif, the basement rocks crop out in three distinct areas: in Yaminué-Nahuel Niyeu, Mina Gonzalito-Sierra Pailemán and Sierra Grande-Arroyo Salado areas (Caminos and Llambías, 1984; Giacosa, 1994, Fig. 1 B). Even though each area is characterized by their particular stratigraphy, lithology, and structures, regional correlation has been attempted between them, considering that all basements might have shared a common geological evolution during the Early Paleozoic (Ramos, 1975; Caminos, 1983, 2001; Caminos and Llambías, 1984; Giacosa, 1987; Busteros et al., 1998; von Gosen, 2002, 2003; Pankhurst et al., 2006, 2014; González et al., 2010, 2011a; Greco et al., 2015 among others). In this regard, equivalent correlative units (Fig. $1 \mathrm{C}$ ) are the coeval low-grade metamorphic rocks, such as Nahuel Niyeu (Caminos, 1983) and El Jagüelito (Ramos, 1975; Caminos and Llambías, 1984; Giacosa, 1987) formations, high-grade metamorphic rocks, such as Mina Gonzalito (Ramos, 1975; Giacosa, 1987) and Yaminué (Caminos, 1983) complexes, as well as deformed and undeformed granitoid plutons, like the Tardugno Granodiorite (Caminos, 1983), Valcheta Granite (Gozalvez, 2009) and the Punta Sierra Plutonic Complex (Busteros et al., 1998).

In the western North Patagonian Massif (Fig. 1 B, Caminos and Llambías, 1984; Giacosa, 1994), the basement rocks are younger since deposition of sedimentary protoliths, metamorphism-deformation and magmatic crystallization ages are mainly Late Paleozoic (Cerredo and López de Luchi, 1998; Varela et al., 1999, 2005; Basei et al., 2005; 


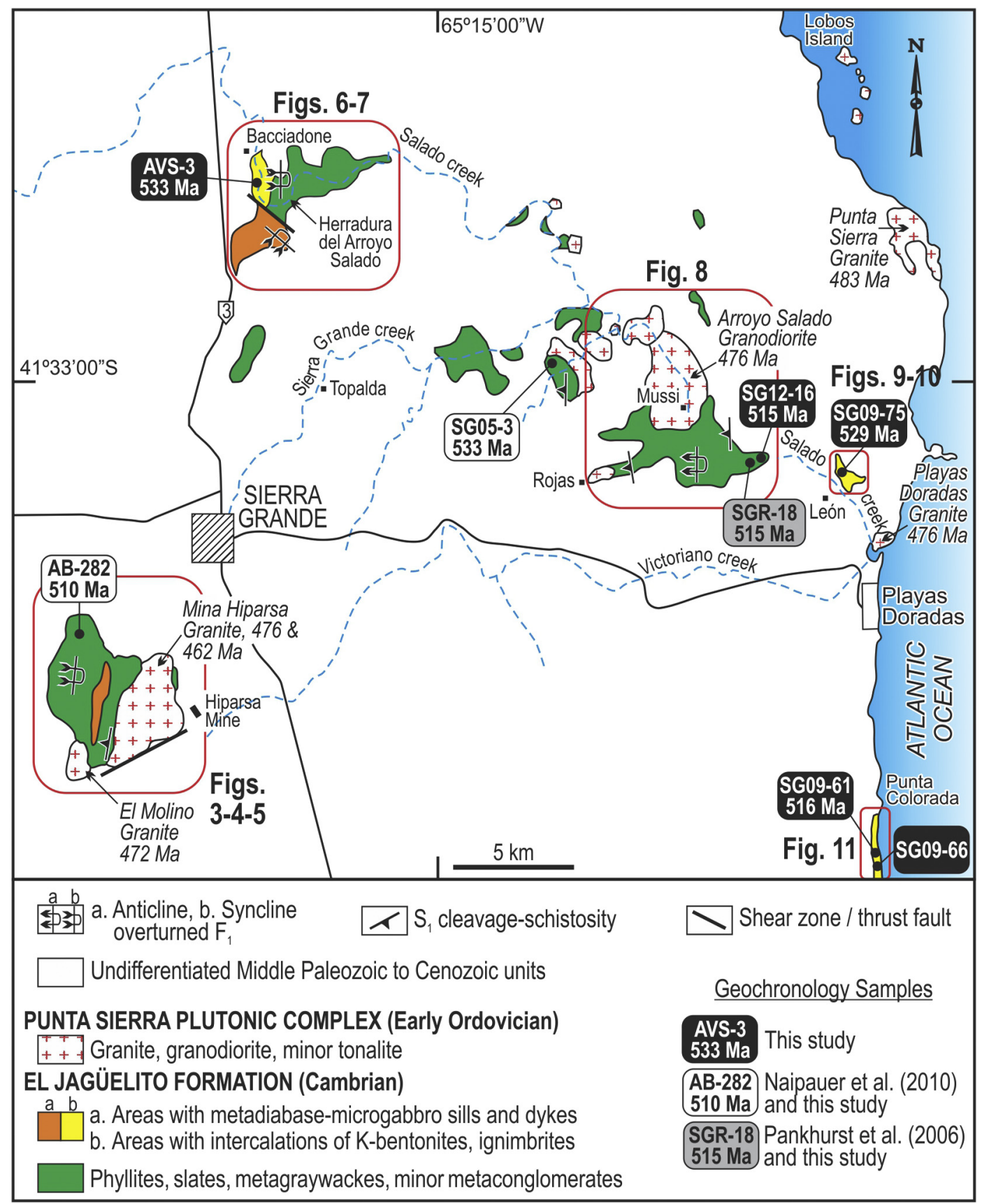

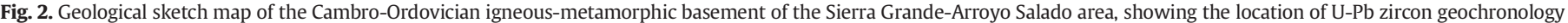

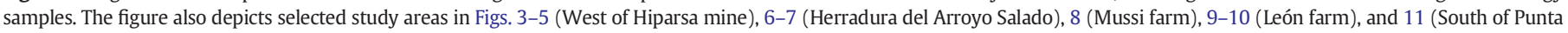
Colorada). Geochronology samples AB-282/SG05-3 and SGR-018 were recalculated from Naipauer et al. (2010) and Pankhurst et al. (2006) respectively.

Hervé et al., 2005; Pankhurst et al., 2006; López de Luchi and Cerredo, 2008; von Gosen, 2009, among others). Thus, this area does not register Early Paleozoic basement rocks as previously assessed (e.g., Dalla Salda et al., 1994) and regional correlations with eastern North Patagonian Massif needs to be re-evaluated considering future mappings and new geochronological constraints.

In the Sierra Grande-Arroyo Salado study area (Fig. 2), the El Jagüelito Formation (Ramos, 1975; Giacosa, 1987) is composed predominantly of slates, phyllites, metagreywackes and metasandstones, and minor intercalations of metaconglomerate lenses and mafic metasubvolcanic rocks (de Alba, 1964; Giacosa and Paredes, 2001; González et al., 2002, 2008a), in addition to felsic meta-volcanic and pyroclastics rocks (González et al., 2011c, 2013). Despite the low-grade metamorphism and ductile deformation affecting this unit, primary clastic sedimentary structures, and igneous features are well preserved (Giacosa and Paredes, 2001; von Gosen, 2002; González et al., 2002, 2011c).

The primary stratigraphic features (de Alba, 1964; Busteros et al., 1998), strontium isotopes (Varela et al., 2014) and imprecise biostratigraphic record provided by rare linguloids and trace fossils (Arnolds, 1952; Braitsch, 1965; González et al., 2002) constrain broadly the deposition of the sedimentary protoliths of the El Jagüelito Formation to Cambro-Ordovician.

The seven taxa of Archeocyath fossil fauna recovered from limestone clasts contained in a metaconglomerate layer exposed to the West of the Hiparsa mine (González et al., 2011a; sample AB-282, Figs. 2, 3) have general affinities with the archeocyathan assemblages from the Australia-Antarctica paleobiogeographic province, indicating an Early 


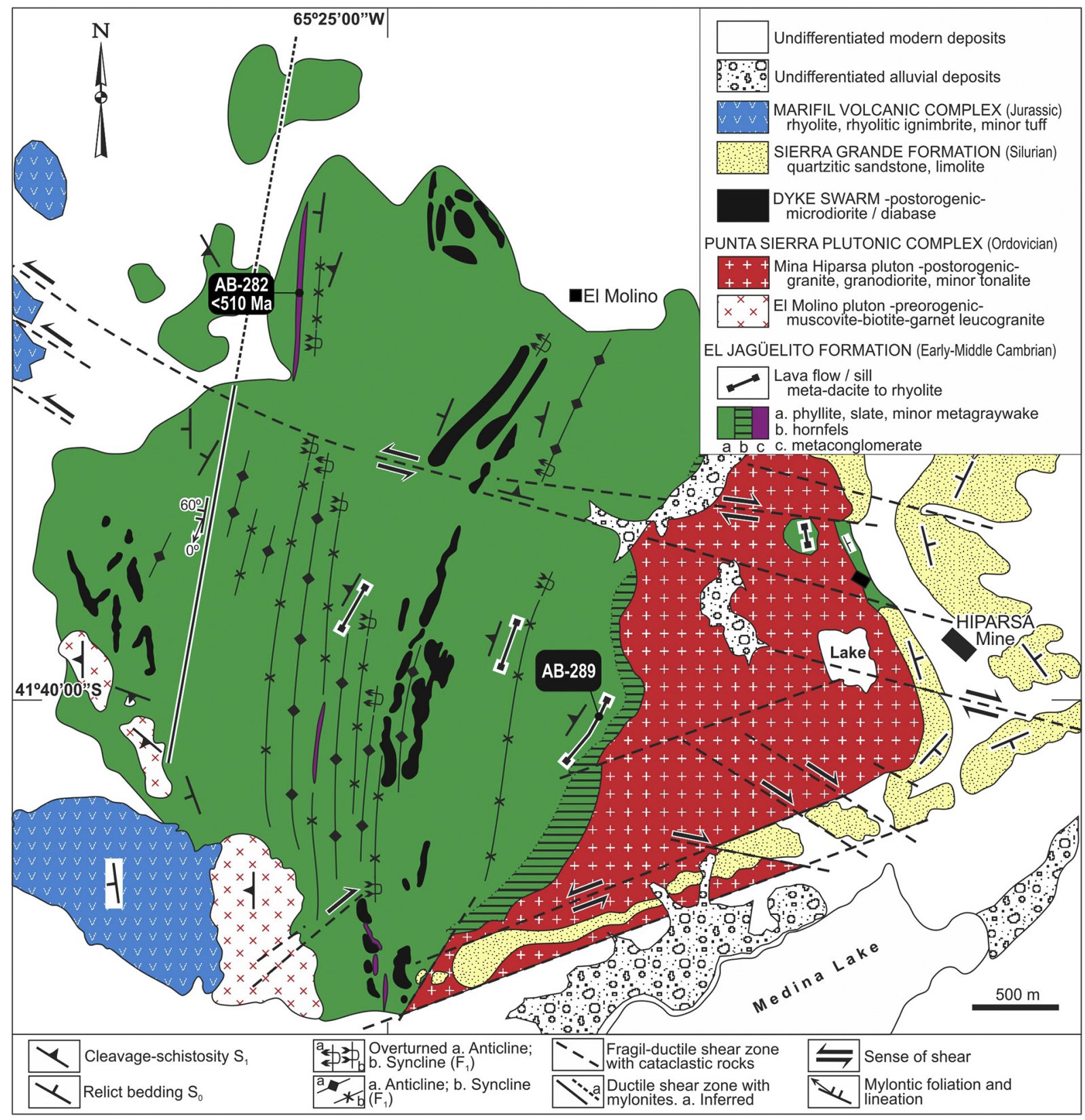

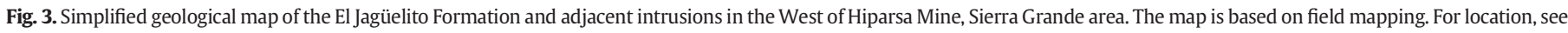
Fig. 2. The fossiliferous metaconglomerate bed AB-282 and sheet-like (meta-) dacitic-to-rhyolitic igneous bodies are indicated (e.g. sample AB-289).

Cambrian (Atdabanian-Botomian: 521-513 Ma, Ogg et al., 2016) association. Thus, deposition of the metaconglomerate is younger than Atdabanian-Botomian but within Cambrian which is also corroborated by U-Pb provenance studies of detrital zircons (Naipauer et al., 2010; Pankhurst et al., 2006).

The calc-alkaline granodioritic to granitic (minor tonalitic) plutons of the Early-to-Middle Ordovician post-orogenic Punta Sierra Plutonic Complex are emplaced in the already deformed and regionally metamorphosed rocks of the El Jagüelito Formation. The U-Pb magmatic crystallization ages of the Punta Sierra Complex are mostly between 476 and $472 \mathrm{Ma}$, with one age of $462 \mathrm{Ma}$ (Varela et al., 1998, 2008; Pankhurst et al., 2006; González et al., 2008c). A Rb-Sr whole rock datum of $483 \pm 22$ Ma was also indicated as magmatic crystallization age to Punta Sierra granite of the same complex (Varela et al., 1997). The older $\mathrm{U}-\mathrm{Pb}$ magmatic crystallization age indicates that whole geological evolution of the El Jagüelito Formation must precede emplacement of the complex (i.e., pre-476 Ma).

Sandstones and quartzites of the Sierra Grande Formation containing fossil faunas of the Hirnantian-early Silurian boundary (Rustan et al., 2013; Siccardi et al., 2014; see also Müller, 1965 and Manceñido and Damborenea, 1984 for a younger Wenlockian age) and post-Late Ordovician U-Pb detrital zircon analyses (Pankhurst et al., 2006; Uriz et al., 2011) unconformably cover both, the eroded metamorphic rocks of the El Jagüelito Formation and the granitoids of the Punta Sierra Plutonic Complex (Fig. 1 C).

The Cambro-Ordovician igneous-metamorphic basement rocks and its Silurian sedimentary cover are in turn intruded by the Laguna Medina granodioritic pluton (U-Pb zircon $291 \pm 5$ Ma, Varela et al. 2009), belonging to the Permian Pailemán Plutonic Complex (Giacosa, 1993; Busteros et al., 1998). A widespread Jurassic volcanic cover of 
the Marifil Complex (Malvicini and Llambías, 1974; Cortés, 1981) and younger formations overlie subhorizontally all the previously described units.

In Yaminué-Nahuel Niyeu area (Fig. 1 B, C), the Nahuel Niyeu Formation is the lithological correlative equivalent of the El Jagüelito Formation and consist of alternating beds of phyllites, slates, metagreywackes, and minor intercalations of metasandstones, metaconglomerate lenses and ultramafic to felsic meta-subvolcanic composite sills (Núñez et al., 1975; Caminos, 1983, 2001; Giacosa, 1994; Chernicoff and Caminos, 1996; Greco et al., 2015). As key correlative features connecting with the El Jagüelito Formation, but without age constraint yet, at least three horizons of meta-tuffs of $<1 \mathrm{~cm}$ thick and two beds of (meta-) pillow-basalts to andesite lava flows have recently been described, all interbedded as part of the same sedimentary sequence (Greco et al., 2015, 2017).

The sedimentary protoliths of the Nahuel Niyeu Formation also have a Cambrian maximum depositional age according to U-Pb detrital zircon ages of c. 515-516 Ma (Pankhurst et al., 2006; Rapalini et al., 2013; Greco et al., 2017) and c. 507 Ma (Rapalini et al., 2013). A SHRIMP U$\mathrm{Pb}$ zircon crystallization age of $513 \mathrm{Ma}$ obtained from a felsic sill is also comparable to the maximum depositional ages of the sedimentary protoliths (Greco et al., 2015).

The intrusion of several granitoids belonging to the Early Paleozoic and the Permian post-orogenic Navarrete Plutonic Complex (Caminos, 1983, 2001; Pankhurst et al., 2006; López de Luchi et al., 2008; Tohver et al., 2008; Rapalini et al., 2013) is also recorded in the Nahuel Niyeu Formation. The Cambrian Tardugno Granodiorite (SHRIMP U-Pb zircon ages of 529, 526 and 522 Ma, Rapalini et al., 2013; Pankhurst et al., 2014 ) is tectonically juxtaposed against the Nahuel Niyeu Formation (von Gosen, 2003) whereas the Valcheta pluton (Ar-Ar muscovite $470 \pm 2$ Ma, Gozalvez, 2009, see also López de Luchi et al., 2008) belonging to the Ordovician Punta Sierra Complex is intruded into this formation.

In the Mina Gonzalito-Sierra Pailemán area (Fig. 1 B, C) further evidence of Cambrian magmatism and sedimentation is in the Mina Gonzalito Complex, which was lithologically considered as the higher grade metamorphic equivalent of the El Jagüelito Formation (Giacosa, 1987, 1994, see also Pankhurst et al., 2006). The high-grade complex is mainly composed of alternating paragneisses, amphibolites and mica schists, with minor intercalations of marbles and pre-to-syn-orogenic granitoids now transformed into orthogneisses (Ramos, 1975; Giacosa, 1987, 1993, 1994; Busteros et al., 1998; González et al., 2008b; Varela et al., 2011). U-Pb detrital zircon analyses from two paragneisses have the youngest age peaks at c. $540 \mathrm{Ma}$ and c. $525 \mathrm{Ma}$, which constrains deposition of the sedimentary protoliths to Early Cambrian, in addition to overgrowths in outer rims at c. $470 \mathrm{Ma}$ and c. 472 Ma pointed out as the age of the main tectono-thermal event of the complex (Pankhurst et al., 2006; Greco et al., 2014). A foliated granodioritic orthogneiss with SHRIMP U-Pb studies has disclosed magmatic crystallization ages in the Furongian ( $492 \pm 6$ Ma, Varela et al., 2011). Lithology and pre-orogenic primary intrusive stratigraphic features of the orthogneiss are comparable to the Punta Sierra Plutonic Complex of the Sierra Grande-Arroyo Salado area, but the latter is early Ordovician, a little younger than primary crystallization of the orthogneiss. This comparison may be the case that, for the same unit but from different structural levels, the crystallization ages in highgrade rocks are usually diachronic, and little older than in the low grade (Lardeaux, 2014).

In summary, the three basement areas of the eastern North Patagonian Massif share a common geological evolution during the Early Paleozoic (Fig. $1 \mathrm{C}$ ).

\subsection{Metamorphism and deformation}

The El Jagüelito Formation is affected by two tectonic-metamorphic events which are both of regional distribution in the eastern North Patagonian Massif. In the first $\mathrm{D}_{1}-\mathrm{M}_{1}$ event, $\mathrm{S}_{0}$ bedding is folded around $\mathrm{E}$ - verging, overturned tight to isoclinal $\mathrm{F}_{1}$ synclines and anticlines with amplitudes and wavelengths in the range of at least several decameters. The N-S to NNE-SSW trending $\mathrm{S}_{0}$ bedding dips steeply to the West, whereas the NNE-SSW to NE-SW trending, penetrative $S_{1}$ axial plane cleavage also dips steeply to the West, but at higher angles. According to the westward-dipping $\mathrm{S}_{0}$ planes, the cross-cutting relationships between $S_{0}$ bedding and $S_{1}$ axial plane cleavage, as well as the " $S-Z$ " geometries of centimeters to meters size $F_{1}$ parasitic folds on different fold limbs, the major $F_{1}$ folds display an E-directed vergence (Giacosa and Paredes, 2001; von Gosen, 2002; González et al., 2002, 2008a, 2011c). Coeval greenschist-facies $\mathrm{M}_{1}$ regional metamorphism reached chlorite to biotite grade (Giacosa and Paredes, 2001; González et al., 2008a, 2011c). Although direct, robust isotopic dating of low-grade metamorphism is lacking, our U-Pb results presented in this contribution constrain the first $D_{1}-M_{1}$ event to Early Ordovician (see Section 5 ), by stratigraphic constraints given by magmatic crystallization of the Punta Sierra Plutonic Complex (González et al., 2008a, 2008c).

The Early Ordovician Punta Sierra Plutonic Complex is emplaced in the already deformed and regionally metamorphosed El Jagüelito Formation, and thus it is post-orogenic concerning the $\mathrm{D}_{1}-\mathrm{M}_{1}$ event. The plutons produce contact aureoles of around $2000 \mathrm{~m}$ thick, e.g., Mina Hiparsa granodiorite (González et al., 2008a, Fig. 3) and Arroyo Salado granodiorite (P.D. González et al., 2014), reached hornblende-hornfels facies contact metamorphism which overprints regional metamorphism. A K-Ar muscovite datum of $459 \pm 9$ Ma (Basei et al., 2005) performed on a metapelitic hornfels from contact aureole of the $476 \pm$ $4 \mathrm{Ma}$ (Varela et al., 1998) Arroyo Salado granodiorite is considered as a cooling age of the contact metamorphism related to this intrusion (P.D. González et al., 2014).

A second tectonic-metamorphic event $\left(D_{2}-M_{2}\right)$ affects not only the El Jagüelito Formation and the Punta Sierra Complex but also the sedimentary cover of the Sierra Grande Formation (Busteros et al., 1998; von Gosen, 2002 and references therein). The $D_{2}$ tectonic event in the El Jagüelito Formation is equal to the first one $\left(=D_{1}\right)$ in both, the Punta Sierra Plutonic Complex and the Sierra Grande Formation. Within the El Jagüelito Formation, the $D_{2}$ structures are discrete $S_{2}$ crenulation cleavage and kink bands which refold $\mathrm{S}_{0}-\mathrm{S}_{1}$ planes. They are oriented EW to NW-SE with dips mostly to the $S$ and SW. Centimeter-scale $F_{2}$ fold axes plunge steeply to $\mathrm{W}$ and WNW. Brittle-ductile shear zones accompany these structures and thrust faults and by coeval local greenschistfacies $\mathrm{M}_{2}$ dynamic metamorphism of Late Permian age (von Gosen, 2002; Basei et al., 2005; Varela et al., 2007, 2009, 2011; P.D. González et al., 2014).

The Permian structures which affect the Punta Sierra Complex are the same as those of the El Jagüelito Formation, as is evidenced by centimeter-to-meter scale brittle-ductile shear zones cutting across the contact between granitoids and its country rocks. Two $\mathrm{Rb}-\mathrm{Sr}$ whole rock-minerals isochrones of $262 \pm 6$ and $263 \pm 9$ Ma from the Mina Hiparsa pluton were considered as resetting ages produced by local $\mathrm{M}_{2}$ shear zone metamorphism during the Late Permian (Varela et al., 2009).

The Silurian Sierra Grande Formation is also affected by folding and thrusting with main NNW-SSE orientation. They are characterized by hundred meters scale open $F_{1}$ folds around NW-SE to NNE-SSW trending axes, plunging north or southward (de Alba, 1964; Zanettini, 1981; Cortés, 1981; von Gosen, 2002). The $F_{1}$ synclines and anticlines are symmetric, and a slight E-NE or W-directed vergence is combined with- and related to high-angle reverse faults (von Gosen, 2002; González et al., 2011c). In most parts of the Sierra Grande Formation, $\mathrm{D}_{1}$ major folds and faults are accompanied by brittle-ductile microstructures, which are all considered of Permian age (Japas, 2001; von Gosen, 2002) by paleomagnetic studies (Rapalini, 1998; Japas, 2001). This $D_{2}$ event of Permian age into Cambro-Ordovician igneous-metamorphic basement rocks and the Silurian sedimentary cover is somewhat part of the Gondwanide deformational history of the North Patagonian Massif (Japas, 2001; von Gosen, 2002). 


\section{Geology of the magmatic protoliths}

The volcanic and pyroclastic protoliths of the El Jagüelito Formation are interbedded parallel to $\mathrm{S}_{0}$ compositional banding of the sedimentary protoliths, and thus all belong to a same volcano-sedimentary sequence. Although they are intercalated in the whole sedimentary succession, their exact relative stratigraphic positions are difficult to define because of tight-to-isoclinal folding and possible repetition of the beds. Thus, tectonostratigraphic successions are broadly considered for the volcano-sedimentary pile of the El Jagüelito Formation.

Volcanic and pyroclastic protoliths are essentially composed of Kbentonites (felsic primary tuffs), ignimbrites and its reworked tuffaceous equivalents, and also by felsic sub-volcanic intrusives domes which all are eminent in the Herradura del Arroyo Salado, Arroyo Salado creek and south of Punta Colorada areas (see locations in Fig. 2). Minor diabase to micro-gabbro/diorite sills and dikes and dacitic-to-rhyolitic sheet-like bodies are also present in the Herradura del Arroyo Salado and West of Hiparsa Mine.

Plutonic protoliths were recognized as part of the El Jagüelito Formation (de Alba, 1964; González et al., 2008c). The deformed El Molino and San Pedro granitic plutons (now orthogneisses) and non-deformed Punta Pórfido granodiorite intrudes the sedimentary protoliths in West of Hiparsa Mine and south of Punta Colorada respectively. According to their granitoid composition, primary intrusive feature (cut $D_{1}-M_{1}$ fabric), and Ordovician age (e.g. El Molino granite, González et al., 2008c), all must be separated from the El Jagüelito Formation and incorporated into the Ordovician Punta Sierra Plutonic Complex (González et al., 2018 in preparation). Since available radiometric constraints are lacking for the San Pedro and Punta Pórfido plutons, we cannot completely rule out Cambrian crystallization ages or even younger as those of the Permian Pailemán Complex.

In this section, we describe primary stratigraphic features for each relevant intercalation of volcano-pyroclastic rocks and related volcanogenic rocks in El Jagüelito Formation which are crucial to trace a comprehensive Early Paleozoic geological evolution. Fig. 2 depicts the five selected study areas cited in the text below.

\subsection{West of Hiparsa Mine, Sierra Grande}

This mapping area is located West of the Hiparsa Mine $\left(41^{\circ} 40^{\prime} \mathrm{S}\right.$ $65^{\circ} 25^{\prime} \mathrm{W}$, near Sierra Grande town), which is well-known as the "Southern Sierra Grande iron deposit" (Zanettini, 1981, 1999). The local stratigraphy includes the igneous-metamorphic basement of the El Jagüelito Formation and the Punta Sierra Plutonic Complex, Silurian quartzites of the Sierra Grande Formation, Permian post-orogenic granitoids belonging to Pailemán Plutonic Complex, and the extensive volcanic cover of the Jurassic Marifil Complex (Fig. 3).

The outcrops of the El Jagüelito Formation are flat to gently undulating and cover an area of approximately $5 \mathrm{~km} \times 4 \mathrm{~km}$. It has poor outcrop situation because they are almost fully covered by xerophytic stumpy vegetation which makes the mapping, structural and metamorphic analysis difficult.

The El Jagüelito Formation consists of alternating beds of slates, phyllites, metagreywackes, hornfels and minor intercalations of granule-to-cobble metaconglomerate lenses and igneous sheet-like beds. The presence of unexposed coeval limestones is inferred from archeocyathan limestone blocks contained in a metaconglomerate layer (see also Section 7). The original $\mathrm{S}_{0}$ bedding consisting of conglomerate, greywacke, and pelite banding is still well-preserved whereas primary sedimentary structures in coarse-grained rocks, such as oscillatory ripple marks, normally graded bedding and cross-bedding, flutes and load casts, are good polarity markers (González et al., 2011a).

Following a brief mention of de Alba (1964), our mappings identified intercalations of a number of NNE-SSW trending (meta-) felsic lava flows or sills, the small granitic body of the El Molino pluton (González et al., 2008c), and a NE-SW longitudinal dike swarm of diabase-microdiorite (Figs. 3, 4 B, C). The lava flows/sills are interbedded parallel to $S_{0}$ compositional banding of the sedimentary protoliths, and thus all belong to the same volcano-sedimentary sequence. Although it is challenging to determine whether they are lava flows or sills due to poor outcrop situation, the igneous bodies are $0.5-1 \mathrm{~m}$ thick tabular sheet-like beds, occasionally up to $6 \mathrm{~m}$, whereas their lengths are up to $270 \mathrm{~m}$ but usually of a few tens of meters. Based on primary igneous mineral associations and textures, they are classified as porphyritic dacites and rhyolites (Fig. $4 \mathrm{~B}$, see also petrography in Section 4).

The lava flows/sills share the same tectonic-metamorphic $M_{1}-D_{1}$ event as that of the host sedimentary rocks, and even one igneous body is incorporated as the inclusion of already deformed and metamorphosed country rock within Ordovician post-orogenic Mina Hiparsa pluton (González et al., 2008c; Fig. 3).

Regarding associated volcanogenic rocks, a metaconglomerate (AB282 ) is a c. $1100 \mathrm{~m}$ long by $10 \mathrm{~m}$ thick bed (see also an expanded description in González et al., 2011a). Clasts are sub-rounded to rounded, poorly sorted pebbles and cobbles of medium sphericity, composed of granitoids, andesites to rhyolites, mono- and polycrystalline quartz, shales, and phyllites. Archeocyathan limestone clasts are minor but large (up to $1.0 \mathrm{~m}$ ) and subangular (Fig. $4 \mathrm{~A}$ ). Microscopic analysis also corroborates an essentially magmatic provenance of detrital components, with minor inputs of metamorphic and calcareous sources (Section 4).

The sub-volcanic dike swarm from West of the Hiparsa Mine is one of two recognized mafic swarms intercalated in the El Jagüelito Formation. The other swarm is composed of sills and crops out at the Herradura del Arroyo Salado (see Section 3.2 below). At the Hiparsa Mine, a N-S to NE-SW trending longitudinal dike swarm of $>4 \mathrm{~km}$ long and $0.3 \mathrm{~km}$ wide spreads northward from Medina lake to Puesto El Molino (Fig. 3). It consists of several post-orogenic dikes, composed of diabase and micro-gabbro/diorite, intruded parallel to $S_{0}-S_{1}$ of the phyllites and metagreywackes with sharp contacts. Thin strips of orange-red thermal oxidation aureoles, fine-grained hornfels and decussated porphyroblast of muscovite were developed along both sides of wall rocks (González et al., 2008c). Most of the dikes are discontinuous and arranged in several separate and tabular shaped segments of few- to tens of meters in width, resulting in an apparent en-échelon intrusion. In a regional distribution, the dykes show a parallel to subparallel orientation, copying the strike and dip of the already regionally structured meta-sedimentary country rocks (Fig. 4 D). Therefore, based on post-orogenic character, petrography, and a K-Ar whole-rock cooling age of $226 \pm 6 \mathrm{Ma}$ (González et al., 2018 in preparation), the dyke swarm is separated from El Jagüelito Formation and incorporated into a post-orogenic Triassic dyke swarm which has regional distribution within the eastern North Patagonian Massif (González et al., 2016).

\subsection{Herradura del Arroyo Salado}

The "Herradura del Arroyo Salado" ( $41^{\circ} 28^{\prime} 30^{\prime \prime} S-65^{\circ} 19^{\prime} 30^{\prime \prime}$ W, Fig. 2) mapping area is around $14 \mathrm{~km}$ north of the Sierra Grande town. The local geology is composed of the El Jagüelito Formation, its Silurian sedimentary cover of the Sierra Grande Formation and younger units (Fig. 5). Previous lithological mappings correspond to Weber (1983), Busteros et al. (1998), Giacosa and Paredes (2001) and González et al. (2011c). A swarm of pre- to syn- $\mathrm{D}_{1}-\mathrm{M}_{1}$ mafic sills and a group of andesitic to trachyandesitic sub-volcanic dikes were formally integrated into the El Jagüelito Formation (González et al., 2011c). However, U-Pb zircon dating of c. $460 \mathrm{Ma}$ and c. $243 \mathrm{Ma}$ in the mafic and intermediate rocks constraint their magmatic crystallization ages to Ordovician and Middle Triassic respectively. According to these ages, primary intrusive relationships with sedimentary protoliths and even petrographic and geochemical features, these igneous rocks are excluded from the El Jagüelito Formation and incorporated into the Ordovician Punta Sierra Plutonic Complex (González et al., 2018 in preparation) and post- 

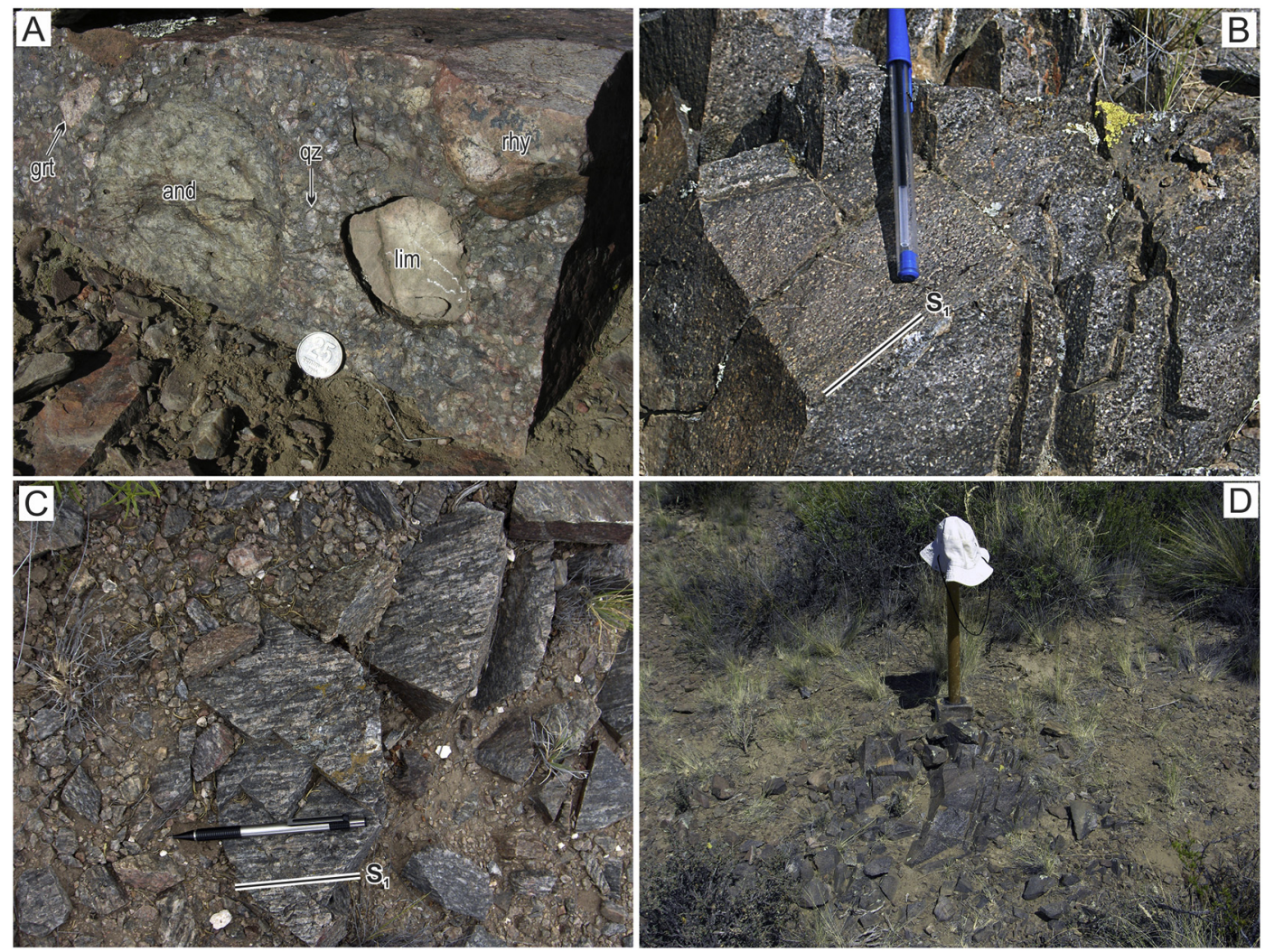

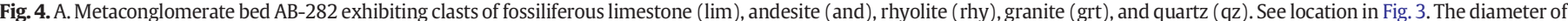

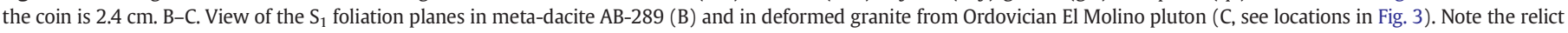

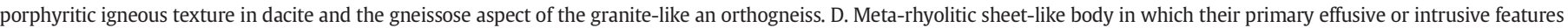
of the bottom and top contacts as either lava flows or sills are unclear due to extremely limited exposures.

orogenic Gondwanide magmatism respectively (P.D. González et al., 2014; S.N. González et al., 2014).

Two blocks of metamorphic rocks of the El Jagüelito Formation are juxtaposed in tectonic contact by a NW-SE striking low-angle reverse fault ("Herradura del Salado thrust") which is ascribed as a major $\mathrm{D}_{2}$ structure (González et al., 2011c; Fig. 5).

The footwall is composed of alternating beds of yellowish-brown (meta-) arkosic pumice sandstones with chalky-white K-bentonites, and green slates, phyllites and minor metagreywackes. The $S_{0}$ bedding is well preserved through the entire succession and consists mainly of K-bentonite and psammite-pelite banding. Within the bedding and bedding plane, primary sedimentary structures are also well preserved and aided mapping as polarity markers. The presence of unexposed coeval limestones is inferred from rare outsized limestone dropstones of uncertain origin in phyllites (González et al., 2011c).

At least six tabular beds of K-bentonites of $<10 \mathrm{~cm}$ thick and derived from ash fall clouds are parallel to $S_{0}$ stratification of meta-arkosic sandstones (Fig. 6 A). The mineralogical composition, X-ray determinations of clay minerals and geochemical features confirms their classification as K-bentonites (see below).

The hanging wall is essentially composed of alternating purple, green slates and phyllites, and minor pinkish meta-greywackes, which defines the $\mathrm{S}_{0}$ compositional banding of the sedimentary succession. The swarm of mafic sills belonging to the Ordovician Punta Sierra Plutonic Complex is also parallel to $\mathrm{S}_{0}$ banding (Fig. 5). Until now, no Kbentonite horizons were recorded in the hanging wall. Rare linguloid fossils suggest a protolith depositional age vaguely to CambroOrdovician (Braitsch, 1965).

The pumice sandstones and K-bentonites share the same $\mathrm{D}_{1}$ structures and $\mathrm{M}_{1}$ regional metamorphism as those of the host sedimentary rocks (Giacosa and Paredes, 2001; González et al., 2011c). Low-grade $\mathrm{M}_{1}$ metamorphism under greenschist facies (chlorite-stilpnomelane grade) is characterized by mineral associations of Chl-Ser-Qtz in metasandstone, Ser-Chl-Ab-Qtz, and Ms-Chl-Stp in metapelites, as well as Ser-Illite/Smectite-Zeolites $\pm \mathrm{Chl} \pm$ Prh in meta-K-bentonites (González et al., 2011c, see also Section 4 below).

\subsection{Lower Arroyo Salado creek}

Two outcrops of the El Jagüelito Formation containing volcanic and pyroclastic intercalations are exposed alongside lower Arroyo Salado creek (Fig. 2). The major is placed close to Mussi farm $\left(41^{\circ} 34^{\prime} \mathrm{S}-65^{\circ} 07^{\prime}\right.$ $\mathrm{W}$ ) whereas the other is smaller and located around $1 \mathrm{~km}$ East of the León farm $\left(41^{\circ} 35^{\prime} \mathrm{S}-65^{\circ} 03^{\prime} \mathrm{W}\right.$, Figs. 7 and 8).

\subsubsection{K-bentonite horizons of the Mussi farm}

Here, the local stratigraphy comprises the El Jagüelito Formation intruded by the Arroyo Salado granodioritic pluton belonging to the Punta Sierra Plutonic Complex and, in turn, both units are unconformably covered by psammitic rocks of the Silurian Sierra Grande Formation (Fig. 7).

The El Jagüelito Formation is mainly composed of hornfels, schists, metagreywackes, slates, phyllites, and metasiltstones, with minor intercalations of metasandstones and granule metaconglomerates. The sedimentary protoliths preserve the original $\mathrm{S}_{0}$ bedding which consists mainly of pelite-psammite banding. Primary sedimentary structures in meta-psammitic rocks, such as oscillatory ripple marks, normally graded bedding and cross-bedding, flutes and load casts, and such as flaser bedding and trace fossils in meta-pelitic rocks (González et al., 2002), are good polarity markers and for correlating strata.

At least fourteen tabular to boudinaged beds of greenish-white Kbentonites of around $10-12 \mathrm{~cm}$ thick and derived from ash fall clouds are intercalated parallel to $S_{0}$ lamination of the greyish green to yellowish slates and phyllites (Fig. 6 B, C, D). The mineralogical composition, X- 


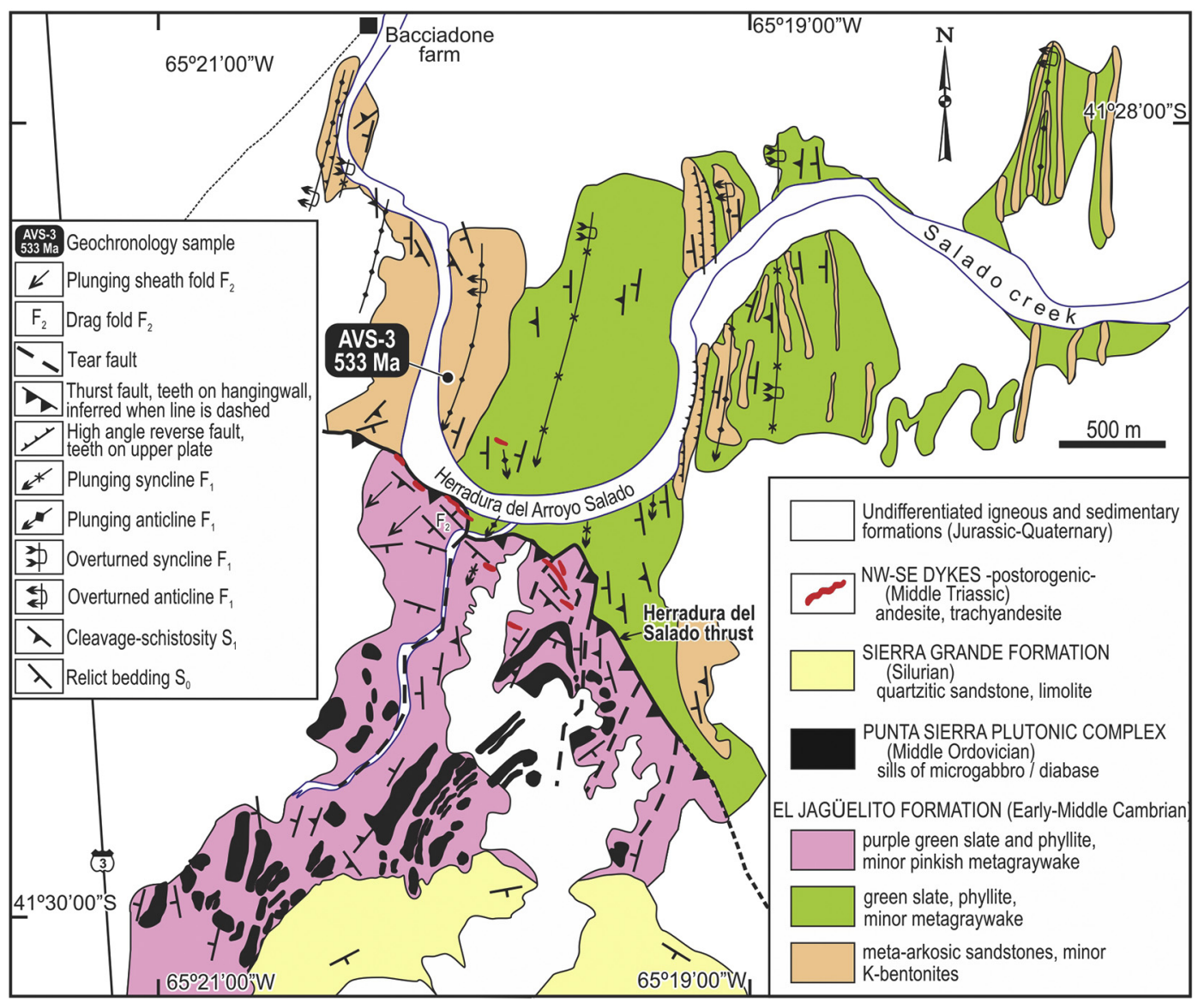

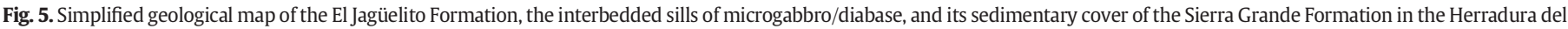
Arroyo Salado. The map is based on field mapping. For location, see Fig. 2. Location of the K-bentonite AVS-3 is indicated.

ray determinations of clay minerals and geochemical features confirms their classification as K-bentonites (see below).

K-bentonites and sedimentary protoliths of the El Jagüelito Formation are affected by the same two regional tectonic-metamorphic events exhibiting in other outcrops of the Sierra Grande-Arroyo Salado area (von Gosen, 2002; González et al., 2013; P.D. González et al., 2014). D structures are accompanied by regional metamorphism $\mathrm{M}_{1}$ that reached greenschist facies characterized by mineral associations of Ms-Bt-PlgPrh-Qtz \pm Turm and Qtz-Plg-Fk-Bt in meta-greywackes, Qtz-Bt-MsChl and Bt-Ms in metapelites, as well as Illite/Smectite-Prh-ZeolitesSer in meta-K bentonites (Fig. 6 D; González et al., 2013; P.D. González et al., 2014, see also Section 4 below).

\subsubsection{The volcano-sedimentary succession of the León farm}

In the León Farm, the local stratigraphy of the Cambro-Ordovician igneous-metamorphic basement includes the El Jagüelito Formation and the non-deformed Boca del Salado granodioritic pluton belonging to the Punta Sierra Plutonic Complex. These units are unconformably covered by psammitic rocks of the Silurian Sierra Grande Formation and by the extensive sedimentary deposits of two marine ingressions, one Paleocene and the other Oligocene-Miocene (Fig. $8 \mathrm{~A}$ ).

The El Jagüelito Formation is composed of alternating yellowishbrown pumice (meta-) sandstones and siltstones, a bed of ignimbrite, and a felsic dome. All these rocks are part of the same explosive subvolcanic dome complex containing a subaqueous intrusive cryptodome and resedimented syn-eruptive volcaniclastic deposits that have a genetic connection with active volcanism (Fig. $8 \mathrm{C}$ ). The dome is hosted in pelitic sediments (now meta-siltstones) and exhibits the geological features of high-level intrusions and also of extrusive lava domes. The siltstones are composed of either sedimentary clastic components or juvenile tephra (see petrography below). A shallow subaqueous marine environment setting is inferred for the subvolcanic complex emplacement (Section 7).

The cryptodome is typically ovate to elliptical covering an area < $0.1 \mathrm{~km}^{2}$. It is composed of somewhat coherent inner part of devitrified lava (vitrophyre?) with "false" granophyric to micro-graphic texture (e.g., McPhie et al., 1993, p. 169) and a chilled outer part or carapace of devitrified hyaloclastite and hyaloclastic breccia. In the western part of the dome, the contact between hyaloclastite and siltstones is locally intermixed and well exposed on a vertical section $25 \mathrm{~m}$ wide and $10 \mathrm{~m}$ high (Figs. $8 \mathrm{~B}, 9 \mathrm{C}$ ). In hyaloclastite, flow banding is parallel to contact, and relict igneous structure of glass is banded perlite comprising perlitic fractures which form a roughly rectilinear network. This structure is accentuated by crystallization of secondary minerals such as goethite and other phyllosilicates and roughly spherical spherulites along the cracks (Fig. $9 \mathrm{D}$ ). In siltstones, bedding $\mathrm{S}_{0}$ is locally folded around $\mathrm{cm}$-scale tight folds formed by dome emplacement (Fig. $9 \mathrm{C}$ ). It is also oxidized owing thermal effect of contact metamorphism. As part of its intrusive feature, the cryptodome also contains a number of inclusions of siltstone now transformed into mottled hornfels. In the eastern part of the cryptodome, the contact with siltstones is blurred and partly covered by modern alluvial sediments and soils. However, contact metamorphism due to the thermal effect of dome intrusion is evidenced by the formation of dotted meta-siltstones. Collapse of a growing shallow subaqueous, partly extrusive cryptodome generates the ignimbrite and pumice volcaniclastic sandstones.

A nearly tabular bed of subaqueous ignimbrite (sample SG09-75) of around $8 \mathrm{~m}$ thick is intercalated parallel to lamination $\mathrm{S}_{0}$ of the siltstones. Basal unconformity of ignimbrite is marked by a sharp erosion surface which cut this lamination. In ignimbrite, primary laminar 


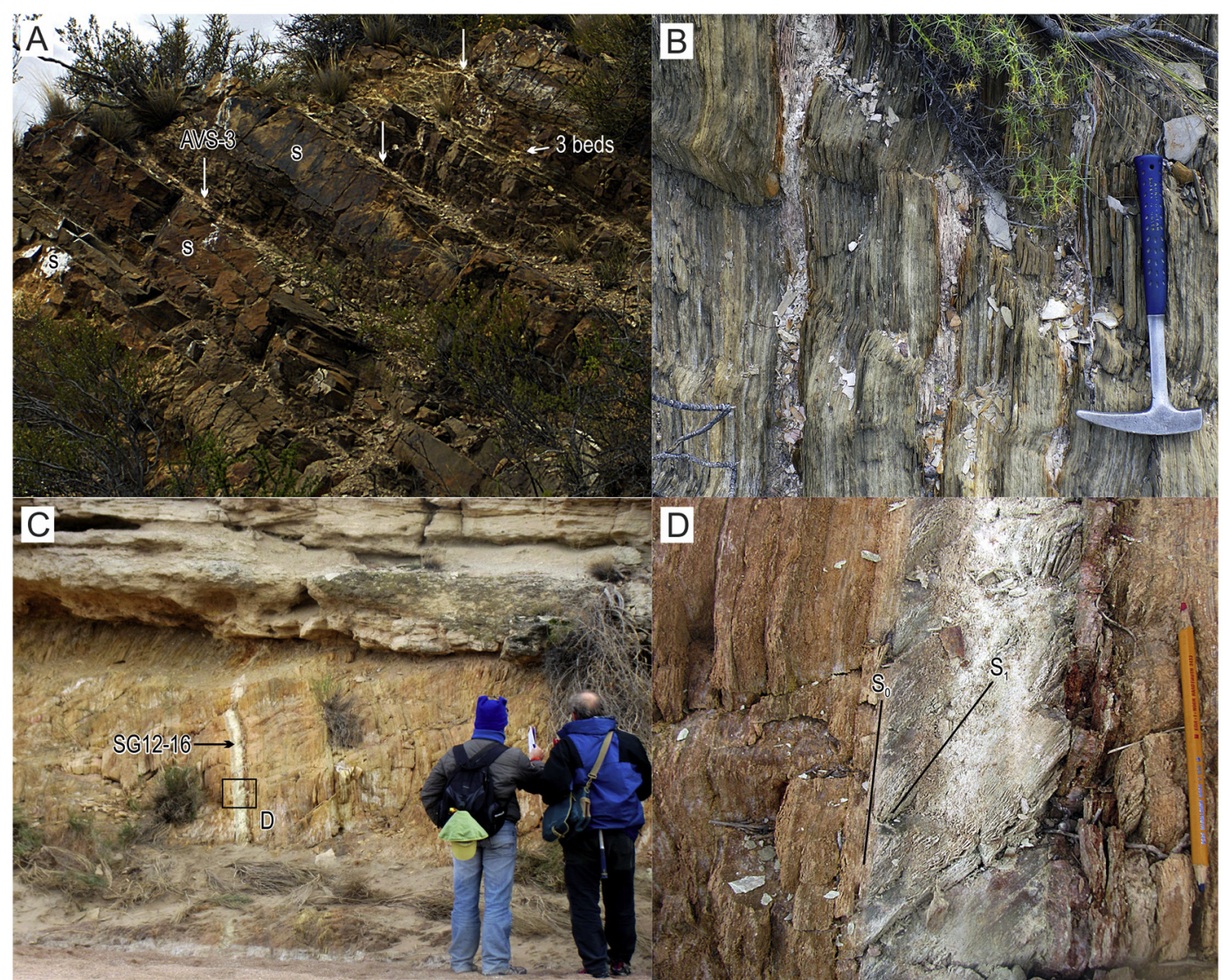

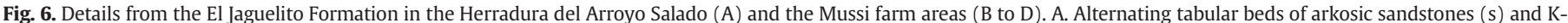

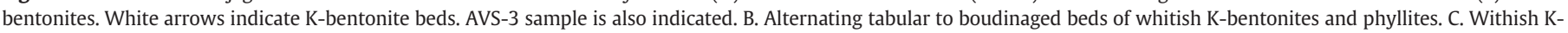

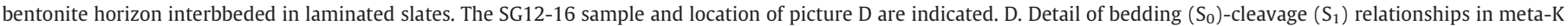
bentonite SG12-16. The bentonitic layer is weaker than the surrounding slate layer and therefore the cleavage $S_{1}$ is better expressed in the former. For locations, see Fig. 2 .

flowage igneous feature such as flow banding/foliation is parallel to the base (Figs. 8 B, 9 A, B). In contact, siltstones are oxidized and transformed into spotted metasiltstone due to the thermal effect of local contact metamorphism produced by the hot ignimbritic flow. The contact metamorphism was of very low-grade since the pyroclastic flow was relatively cold due to interaction with cold seawater. Then, siltstones were not transformed into hornfels. The top contact of the ignimbrite is faulted, tectonically juxtaposed with siltstones and sandstones of the same sequence (Fig. 9 B, see also below).

A tabular bed $5 \mathrm{~m}$ thick and some $<1 \mathrm{~m}$ thick layers of pumice sandstone are intercalated in epiclastic and pumice siltstones with sharp contacts (Fig. 9 E). Siltstone layers are $<1 \mathrm{~m}$ thick and are usually interbedded with beds of mudstone of around $25 \mathrm{~cm}$ thick. The thickest sandstone bed is readily distinguishable because of uniform composition and common sedimentary structures and is traceable over outcrop distances. As a result, it is a key bed which can be used as a polarity marker horizon for mapping and reconstructing the folded structure (Fig. 8 B). In top contact, the primary sedimentary structures are tabular cross-bedding or trough cross-bedding whereas at the base ripple marks and flutes are frequent. The basal contact of the sandstone bed is marked by irregular erosional disconformity surface which cut $\mathrm{S}_{0}$ lamination of siltstone. On a volcano-genetic point of view, the pumice sandstones are interpreted as shallow subaqueous resedimented syneruptive volcaniclastic deposits, dominated by traction current bedforms (e.g., McPhie et al., 1993, p. 6-7). Their petrographic features (see Section 4) are equal to those of the arkosic sandstones from Herradura del Arroyo Salado and therefore they can be considered as lithological correlative equivalents.

$\mathrm{D}_{1}$ structures are upright open to tight $\mathrm{F}_{1}$ folds of decameter scale affecting the volcano-pyroclastic/epiclastic banding $\mathrm{S}_{0}$ of the rocks (Fig. 8
B) and related fanning axial plane cleavage $S_{1}$ (Fig. 9 B). The high-angle normal fault in the hinge zone of a major syncline containing the ignimbrite is interpreted as caused by hinge collapse of this competent layer that occurs between incompetent beds of meta-siltstones (Figs. 8, 9 A). Although this fault is related to the formation of $F_{1}-S_{1}$ structures and then it is ascribed to the $\mathrm{D}_{1}$ deformational event, its volcanotectonic relationship before $\mathrm{D}_{1}-\mathrm{M}_{1}$ remains unclear.

Coeval to $D_{1}$ structures, very low-grade regional metamorphism $M_{1}$ is represented by an association of Ms-Phr in meta-ignimbrite, Ser-MsChl-Prh-Pump-Zeolites and Ms-Ser-Ab in pumice sandstones and siltstones, and Chl-Prh-Pump and Ab-Chl-Zeolites-Prh-Pmp \pm carbonates in the felsic dome, which are all indicative of prehnite-pumpellyite-facies transitional to greenschist facies (Section 4).

The undeformed and non-metamorphosed Boca del Salado granitic pluton belonging to the Ordovician Punta Sierra Plutonic Complex (SHRIMP U-Pb zircon $476 \mathrm{Ma}$, Pankhurst et al., 2006) is exposed as small, isolated outcrops in a beach berm near the estuary of the Arroyo Salado creek. $1.5 \mathrm{~km}$ northwest, close to Rincón Hill, a minor outcrop of spotted phyllitic slate can be attributed as the country rock thermally affected by local contact metamorphism produced by granite intrusion (Fig. $8 \mathrm{~A}$ ). The slate is composed of fine-grained chlorite + sericite \pm prehnite defining planes of $S_{1}$ slaty cleavage which are overprinted by post- $S_{1}$ porphyroblasts of retrogressed cordierite.

\subsection{South of Punta Colorada}

The igneous-metamorphic basement south of the Punta Colorada area $\left(41^{\circ} 45^{\prime} \mathrm{S}-65^{\circ} 01^{\prime} \mathrm{W}\right)$ is poorly exposed in the beach berm of the Argentine Seacoast for $>5 \mathrm{~km}$ long, particularly during the low tide in a narrow strip of around $400 \mathrm{~m}$ widths. Onshore, further north to San 


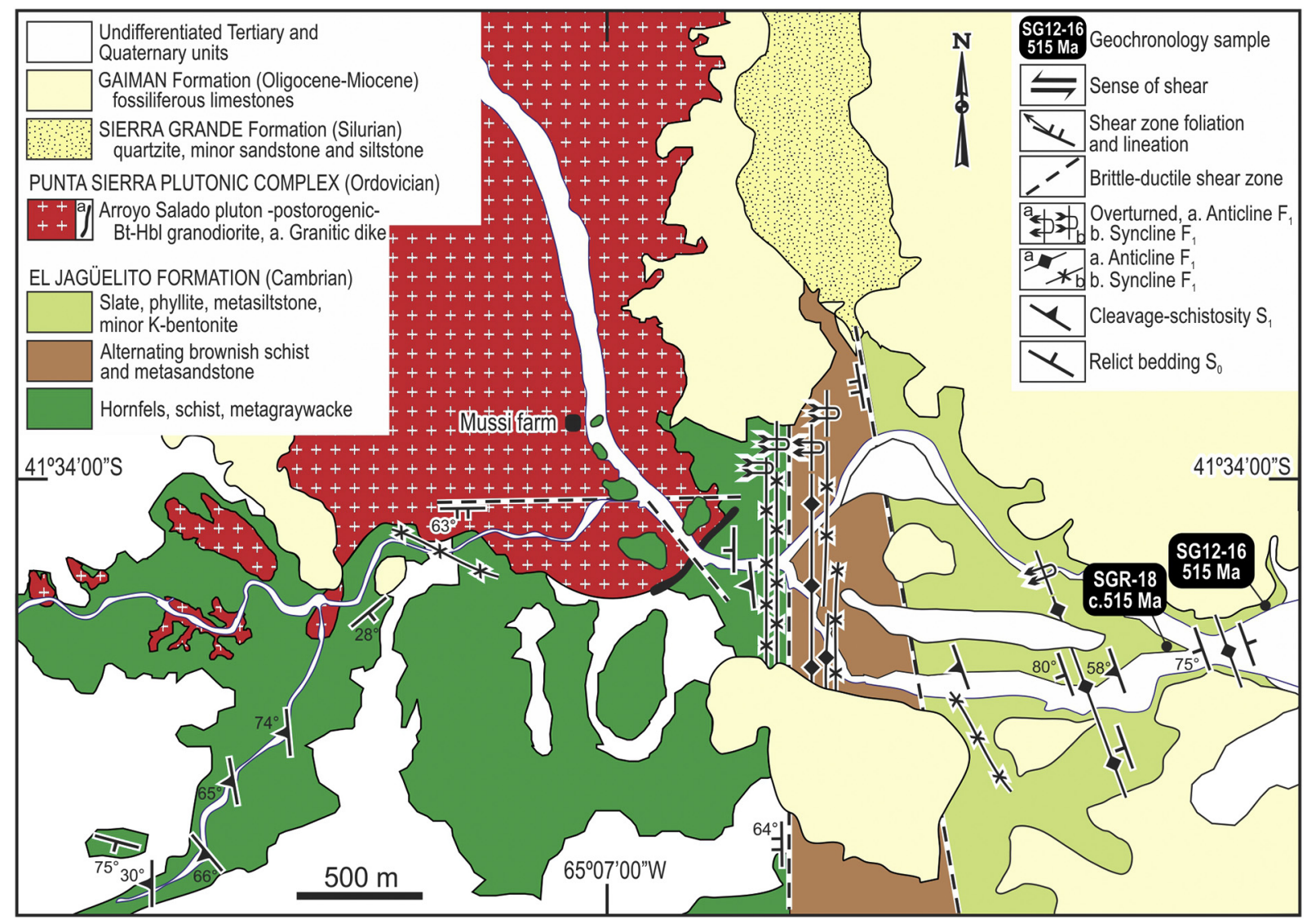

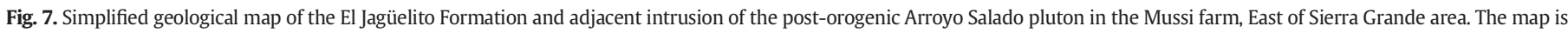
based on field mapping. For location, see Fig. 2. Location of the K-bentonite SG12-16 and metagraywacke SGR-18 samples are indicated. Sample SGR-18 from Pankhurst et al. (2006).

Pedro farm, there is another outcropping of basement covered by Quaternary deposits (Figs. 2,10). Brief mentions of these basement rocks were previously made by de Alba (1964) and Gelós et al. (1990).

Despite the poor outcrop situation, the basement reveals a comprehensive diversity of metamorphic and igneous rocks. Volcanic and pyroclastic protoliths of the El Jagüelito Formation and the San Pedro and Punta Pórfido granitoid plutons are for the first time documented and described. Structures affecting basement rocks are also varied and include those from Early and Late Paleozoic tectonic-metamorphic events, and can be even younger since many structures also affect the Jurassic volcanic cover of the Marifil Complex.

In the berm, the El Jagüelito Formation consists essentially of alternating beds of phyllites, metagreywackes, and hornfels, with minor intercalations of volcanogenic pebble to granule metaconglomerate lenses. Some (meta-) ignimbrite and pyroclastic agglomerate beds and trachytic lava flows are interbedded parallel to $S_{0}$ pelite/psammite banding of the sedimentary protoliths whereas sub-volcanic intrusive bodies, such as domes, feeder necks, and dikes cut $\mathrm{S}_{0}$ banding (Fig. 11). All magmatic rocks are products of a same effusive-explosive subaerial complex (stratovolcano?) containing pyroclastic and lava flows that have a genetic connection with subvolcanic intrusive bodies.

A bed of rhyolitic ignimbrite (sample SG09-66) around $1.0 \mathrm{~m}$ thick is intercalated with tabular beds of meta-trachytes 1.0 to $1.5 \mathrm{~m}$ thick and a bed of agglomerate. Pinch and swell structure is prominent in all these competent layers. The ignimbrite displays a distinctive eutaxitic texture indicated by welding of pumice clasts or fiammes which defines a discontinuous layering (Fig. 11 B). Crystal fragments of quartz and plagioclase are embedded in a devitrified matrix. We do not completely rule out that pumice clasts have also been flattened and stretched by subsequent deformation, resulting in a foliated fabric that mimics primary eutaxitic texture. This ignimbrite does not show any significant petrographic feature (e.g., quenching textures, hyaloclastite, albitization, among others) which represents the interaction between ignimbritic flow and seawater. Therefore, the flow can be interpreted as subaerial but adjacent to a shore. The eutaxitic texture is typical in subaerial welded ignimbrites that were emplaced hot and collapsed under their weight (Beavon et al., 1961; Gifkins et al., 2005a).

The massive, matrix-supported agglomerate consist of sub-rounded to rounded bombs of devitrified pumices, dispersed in a matrix of recrystallized bubble-wall shards. Pumices are now flattened due to load compaction after deposition or to subsequent deformation, resembling eutaxitic texture in welded ignimbrite (e.g., Gifkins et al., 2005a). In general, agglomerates are restricted to proximal volcanic settings. Finally, coherent porphyritic trachytes consist mainly of euhedral plagioclase phenocrysts embedded in an aphanitic groundmass and minor and rare felsic aphanitic clasts (Fig. $11 \mathrm{~B}, \mathrm{C}, \mathrm{D}$ ).

Co-magmatic intrusive domes, feeder necks, and dikes are subvolcanic equivalents of lava flows, and then they are also composed of trachytes. The bodies cut $S_{0}$ banding or even $S_{0}-S_{1}$ foliations with sharp contacts and show a well-marked change in texture, ranging from aphanitic/micro-porphyritic in chilled margins to porphyritic or fine-grained equigranular textures in cores. Flow foliation and flow folds are common igneous features in chilled margins (Fig. 11 E, F).

A $1.0 \mathrm{~m}$ thick bed of a volcanogenic conglomerate (sample SG09-61) is intercalated in the same sequence of metagraywackes and phyllites which also contains the intercalations of trachytes and ignimbrite (Fig. $11 \mathrm{G}$ ). The matrix-supported conglomerate preserves a crude $\mathrm{S}_{0}$ stratification and ripple-marks, and its magmatic provenance of detrital components is revealed by sub-rounded to rounded pebbles to granules of andesites, trachytes, and trachyandesites, devitrified pumices and granitoids, with minor mono- and polycrystalline quartz. The petrography of volcanic clasts is the same as those of the dikes, necks and lava 


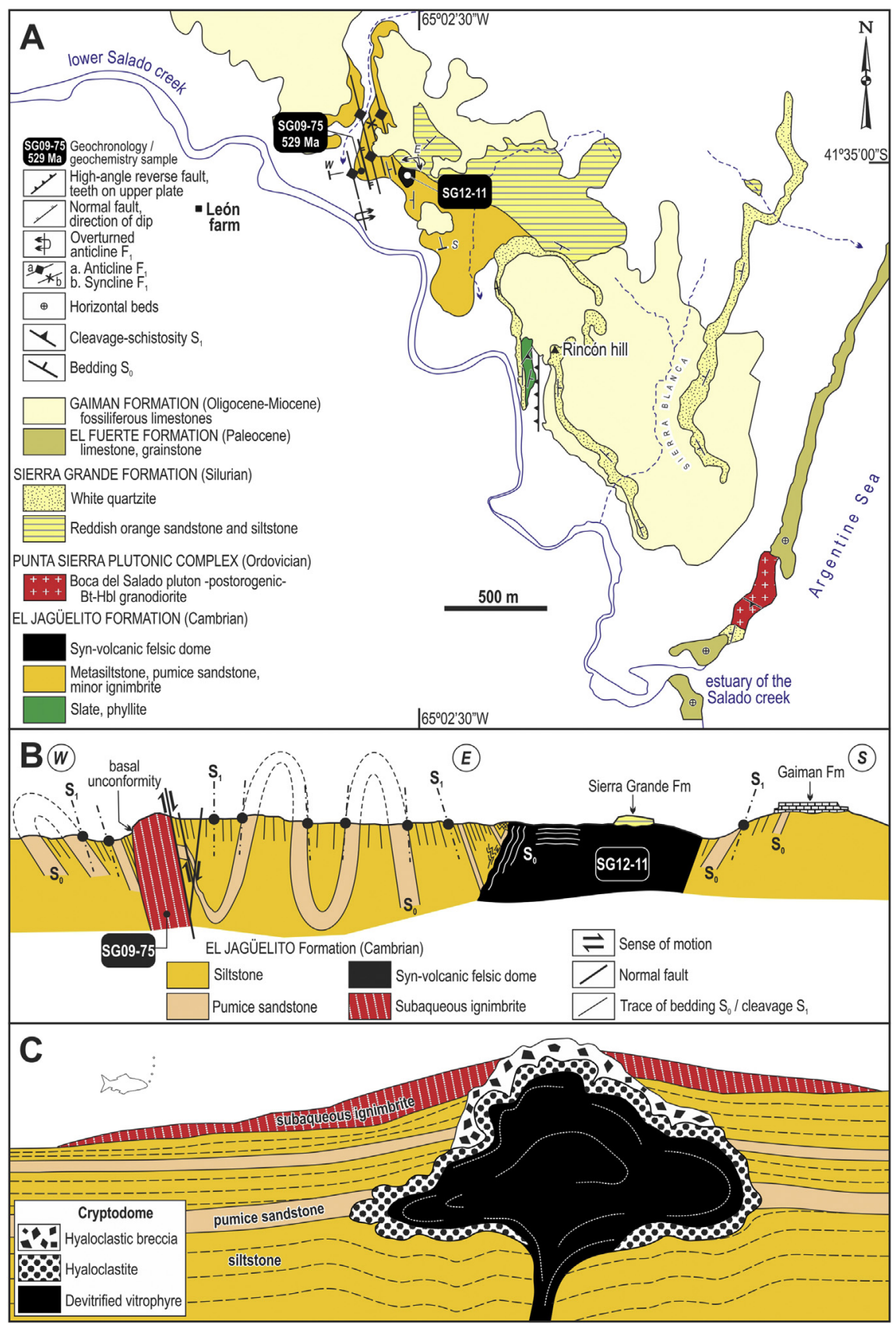

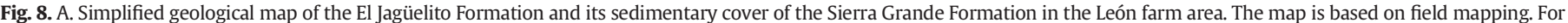

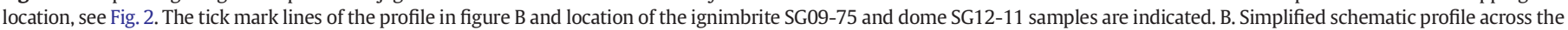

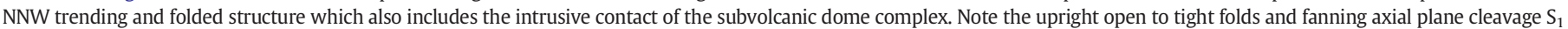

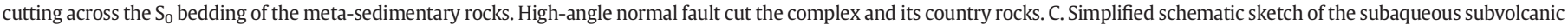

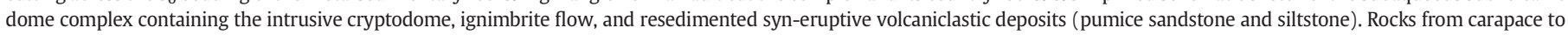
core of the cryptodome and internal primary flow-banded/laminated structure of devitrified vitrophyre are also indicated.

flows, therefore indicating a proximal setting connection with volcanopyroclastic source area. Microscopic analysis also corroborates an essentially magmatic provenance of detrital components, with minor inputs of metamorphic sources (see petrography below). Archeocyathan limestone clasts which are distinctive in the metaconglomerate AB-282 were not found here.

Two non-deformed granodioritic bodies intrude phyllites and metagreywackes, i.e., the Punta Pórfido stock and a pluton exposed as small, isolated outcrop north of Punta Pórfido (Fig. 10). The Punta Pórfido pluton cut $\mathrm{M}_{1}-\mathrm{D}_{1}$ fabric in the metamorphic rocks of the El Jagüelito Formation and then can be classified as post-orogenic. It contains many inclusions of these country rocks now transformed into hornfels. The contact between the pluton and the El Jagüelito Formation is sharp and is in turn cut by dikes fed from granite (Fig. $11 \mathrm{~A}$ ). A belt of hornfels of around $200 \mathrm{~m}$ thick and containing cordierite porphyroblasts develops along its northern contact. According to primary intrusive features, the Punta Pórfido pluton might belong to the Punta Sierra Complex, and then its magmatic crystallization age would be Ordovician. However, considering its post-orogenic character, we cannot completely rule out that it can be younger and therefore part of the Permian Pailemán Plutonic Complex.

North to the San Pedro farm, the El Jagüelito Formation is composed of alternating yellowish siltstones and pumice sandstones, all intruded by andesitic dikes. A tabular bed of $\sim 1 \mathrm{~m}$ thick of pink arkosic sandstone 

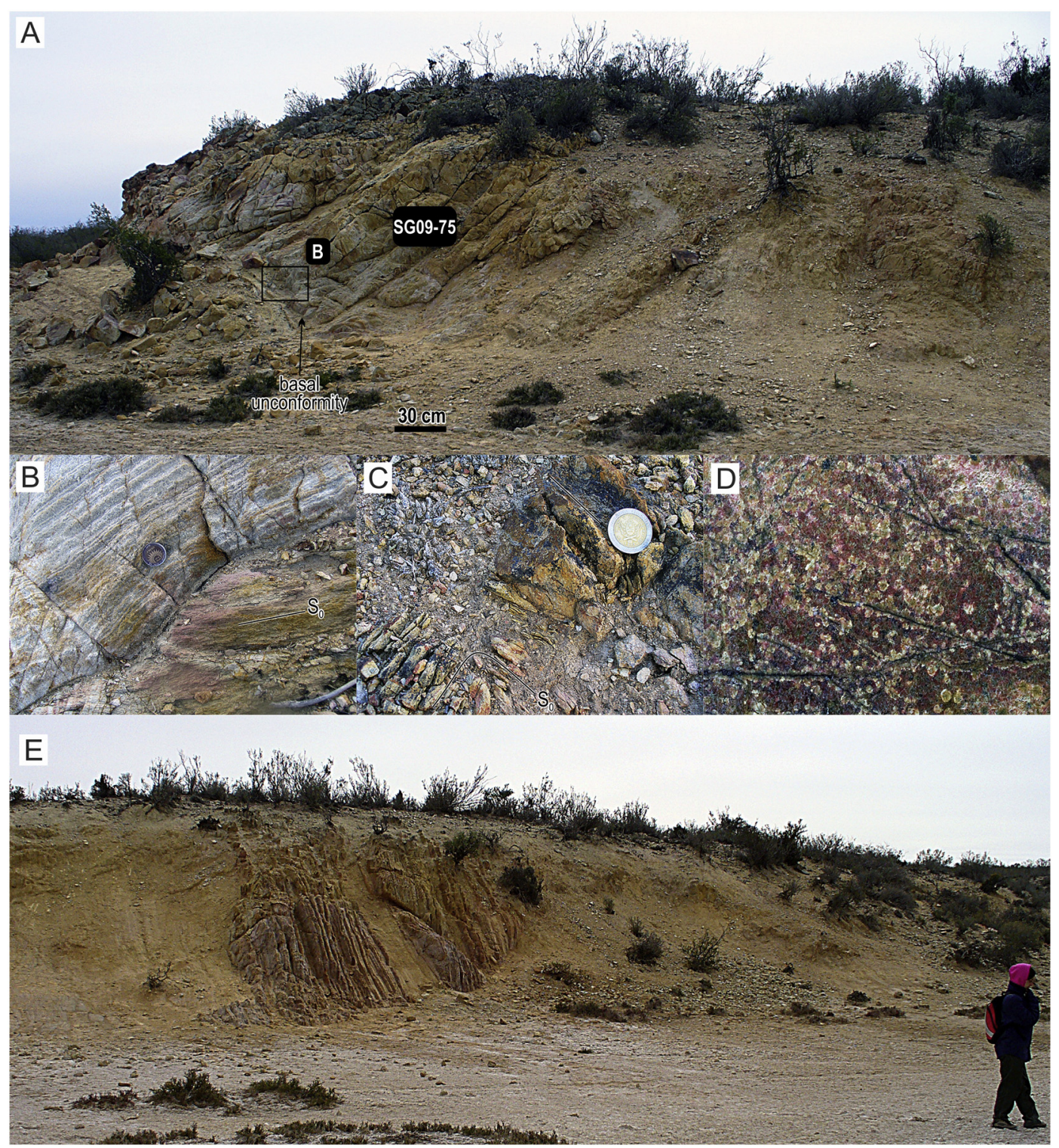

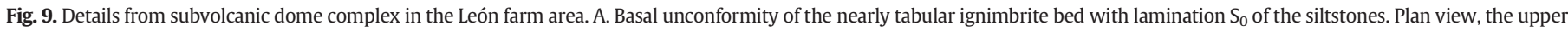

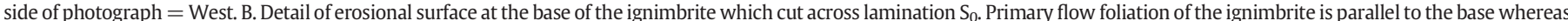

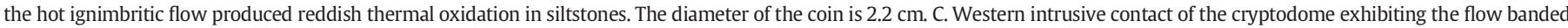

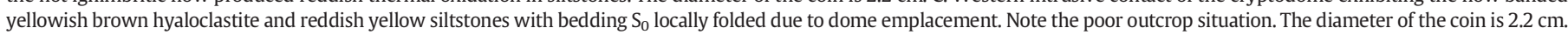

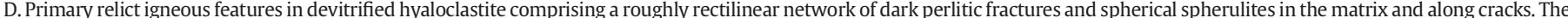

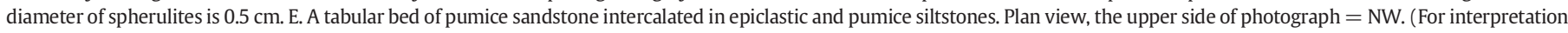
of the references to color in this figure legend, the reader is referred to the web version of this article.)

is intercalated in pumice sandstones. The compositions, petrographic and volcanogenic features of these rocks are the same as those pumice sandstones of the León farm. As a result, both regions seem to share the same volcano-pyroclastic genetic processes. In the top contact of pumice sandstones, the primary sedimentary structures are tabular cross-bedding and ripple marks (Fig. $11 \mathrm{H}$ ). Their basal contact is marked by an irregular erosional paraconformity surface which is parallel to $S_{0}$ lamination of siltstones. On a volcano-genetic point of view, these sandstone beds are interpreted as those of the León farm, that is, shallow subaqueous resedimented syn-eruptive volcaniclastic deposits, dominated by traction current bedforms.

The deformed San Pedro granitic pluton crops out as a N-S trending strip of around $900 \mathrm{~m}$ long and $100 \mathrm{~m}$ wide, which is mostly covered by modern alluvial sediments (Fig. 10). The pluton is tectonically juxtaposed with siltstones and sandstones by an N-S trending and West dipping ductile shear zone. According to structural relationships, the granite, now an orthogneiss, intruded still undeformed sedimentary protoliths of the El Jagüelito Formation, and both were then deformed and regionally metamorphosed together. Thus, the San Pedro granite pluton is pre-orogenic concerning the $D_{1}-M_{1}$ tectono-thermal event and is comparable to El Molino Pluton from West of the Hiparsa Mine (González et al., 2008c). Based on regional geological knowledge, the San Pedro pluton might belong to the Punta Sierra Plutonic Complex, and thus we can envisage a magmatic crystallization age as old as Ordovician or even older. A Cambrian age comparable to the Tardugno granodioritic pluton from the Yaminué-Nahuel Niyeu area cannot be completely ruled out (Fig. 1).

\section{Petrography and X-ray diffraction analyses}

The petrographic study was focused on K-bentonites, ignimbrites, and related volcanic rocks, and also on two volcanogenic conglomerates 


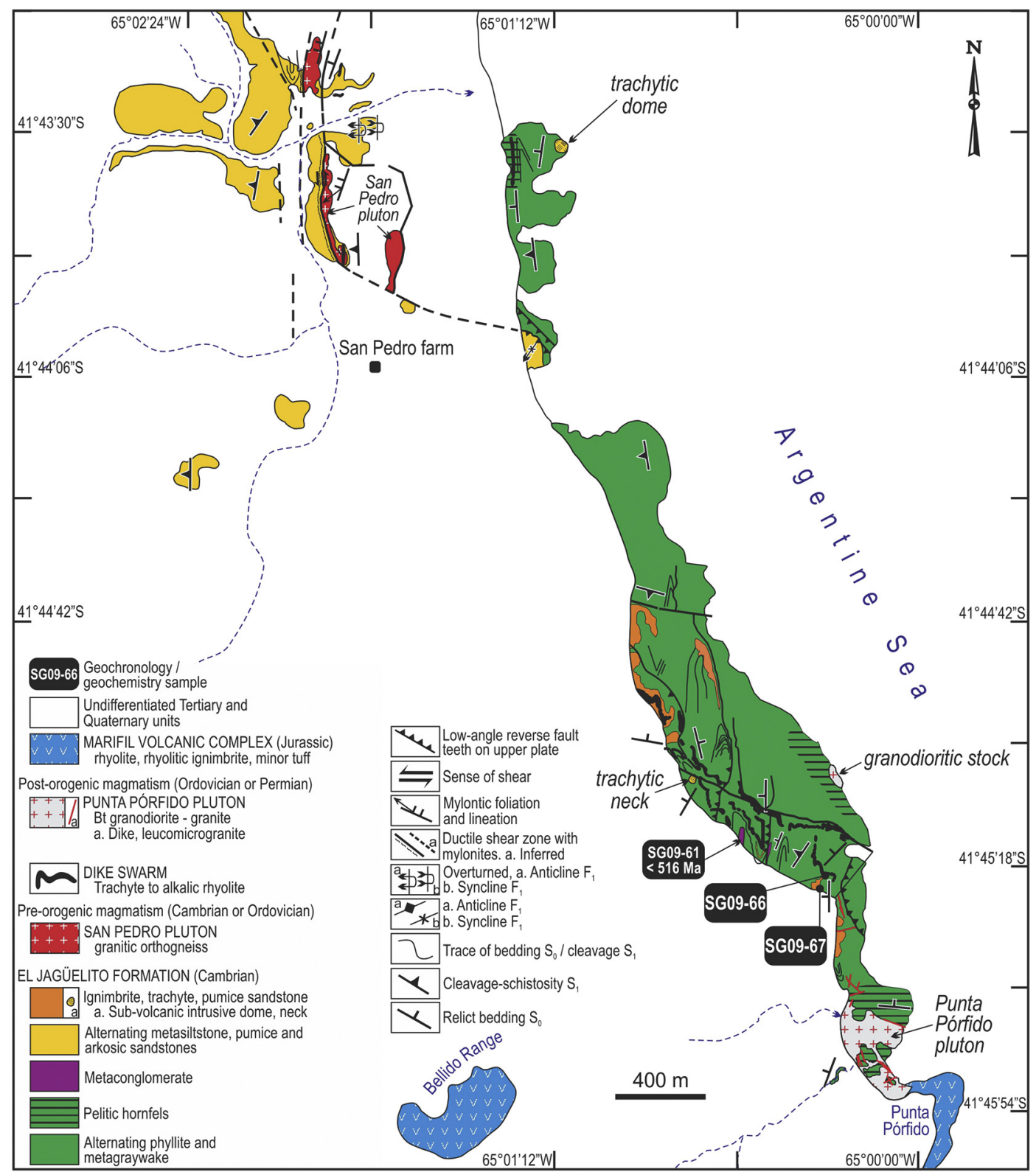

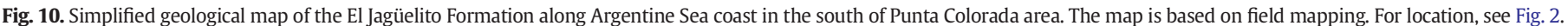
Location of the ignimbrite SG09-66, lava flow SG09-67, and volcanogenic conglomerate SG09-61 samples are indicated.

due to their major magmatic provenance. Petrography is based on mineralogical and textural analyses of thin sections using standard optical microscopy. It was performed at the Petrography Laboratory of the Instituto de Investigación en Paleobiología y Geología (Universidad Nacional de Río Negro), with a Nikon ${ }^{\circledR}$ Eclipse E 200 microscope integrated with MOTIC® Moticam10 digital high-definition camera and application software Motic Images Plus 2.0, with dual output to a computer and directly to an imaging device. The analysis included basic mineral and fabric description, visual estimation of grain size, mineral abundances, and rock classification. The nomenclature of the primary and secondary igneous textures and genetic classification of volcano-pyroclastic deposits is based on McPhie et al. (1993) and Gifkins et al. (2005b).

Two K-bentonites were also analyzed with X-ray diffraction patterns to determine the composition of clay mineral fraction. X-ray diffraction analyses of whole rock powders and clay fraction $(<2 \mu \mathrm{m})$ were performed at the DRX Laboratory of the Facultad de Ciencias Naturales y Museo (UNLP, La Plata), according to standard procedures and analytical conditions summarized in Varela et al. (2013) and Raigemborn et al. (2014).

\subsection{Metaigneous rocks}

West of the Hiparsa mine (Sierra Grande), lava flows or sills of porphyritic dacites display variably sized phenocrysts of plagioclase and amphibole with minor quartz and biotite, embedded in a groundmass of recrystallized plagioclase and amphibole $\pm \mathrm{K}$-feldspar, with apatite and zircon as accessory minerals. Quartz phenocrysts contain rounded inclusions of the groundmass. Porphyritic rhyolites also show phenocrysts of K-feldspar, plagioclase, quartz and minor garnet, embedded in a groundmass of relict granophyric texture. Primary igneous textures neither depict the effusive or intrusive feature, like a lava flow or a sill respectively.

As key metamorphic characteristic of recrystallized groundmass, $\mathrm{S}_{1}$ cleavage planes are marked by sericite + chlorite + biotite + quartz alignment (Fig. $12 \mathrm{~A}, \mathrm{~B}$ ) which also defines lepidoblastic texture. This 


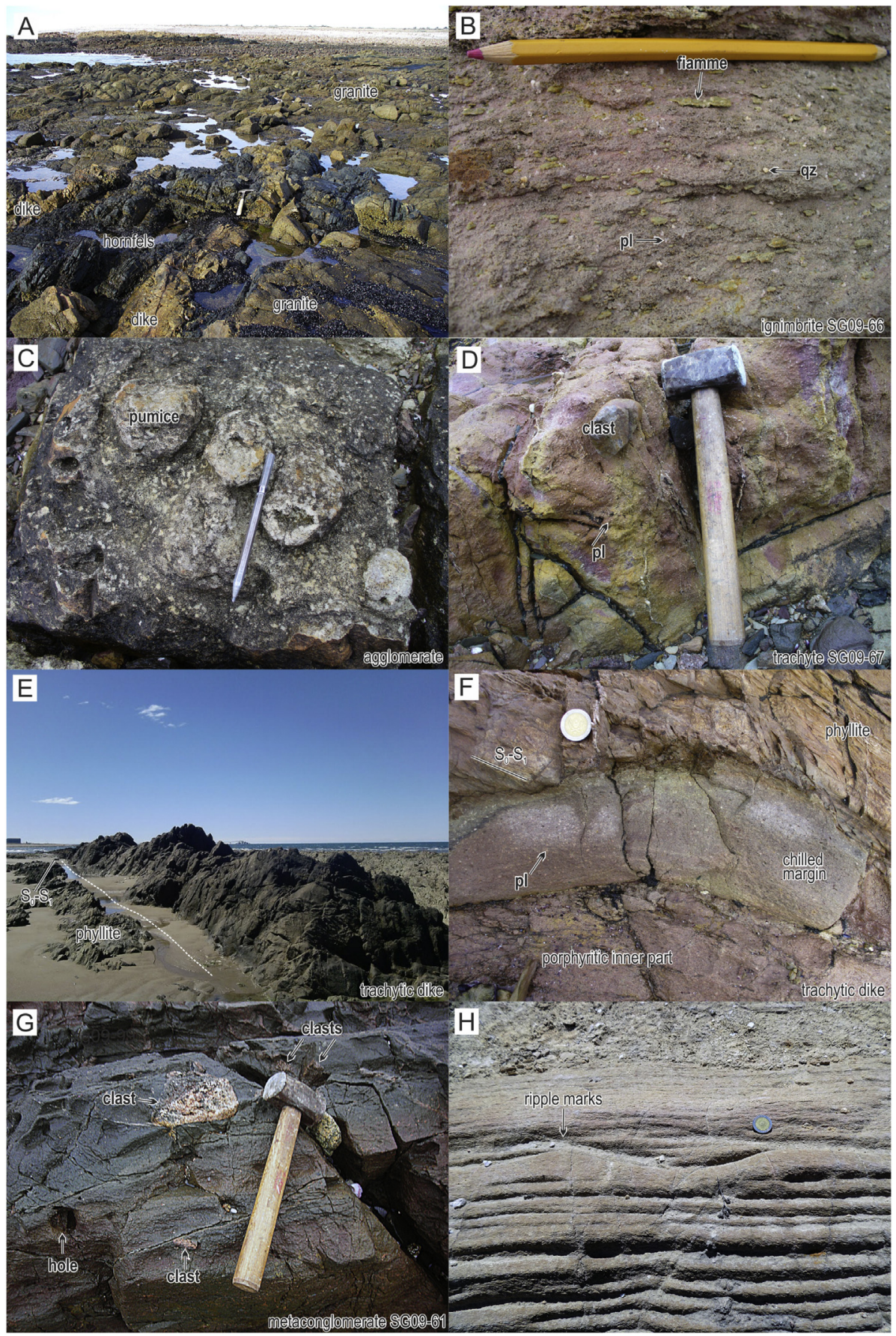

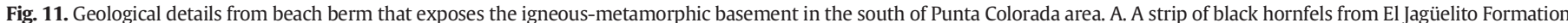

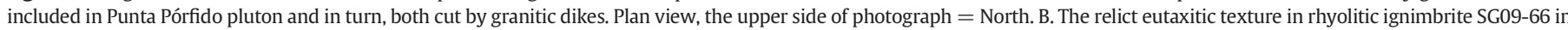

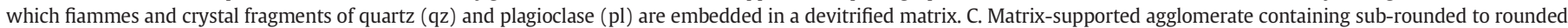

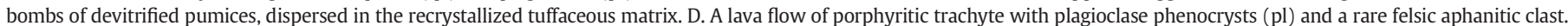

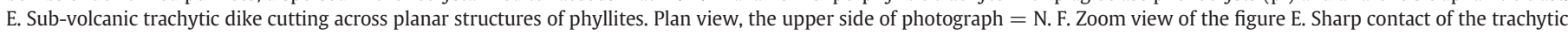

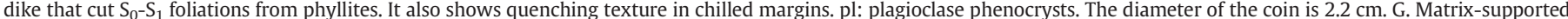

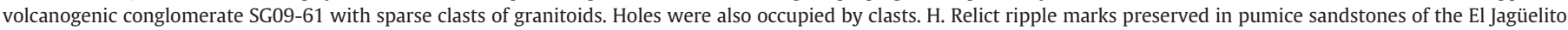
Formation, North to the San Pedro farm.

assemblage is typical of greenschist facies (biotite grade) $M_{1}$ regional metamorphism (Spear, 1995). Deformation lamellae distinguish the intra-crystalline deformation of phenocrysts, undulose extinction and sub-grains in quartz and kinked or tapered albite twins towards the grain boundary in plagioclase and undulose extinction in K-feldspars.

In the Herradura del Arroyo Salado, horizons of the K-bentonites are buff- to tan-colored bands (Fig. 6 A). Primary volcanic features of the Kbentonites are constant among different beds. Sample AS-3 is composed of sub-millimeter sized, sub-rounded devitrified pumice clasts and phenocrysts of quartz as typically six-sided prisms with steep pyramidal terminations and feldspars (Fig. $13 \mathrm{~A}, \mathrm{C}$ ). The proportions of these phenocrysts are constant among different beds, although sometimes quartz prevails over feldspars. Apatite and zircon are accessory minerals. The primary glassy matrix is now devitrified and recrystallized to very fine-grained aggregates of sericite, clay minerals (mostly illite, see XRD analysis in Section 5.1.3), zeolites, chlorite, and prehnite, which 


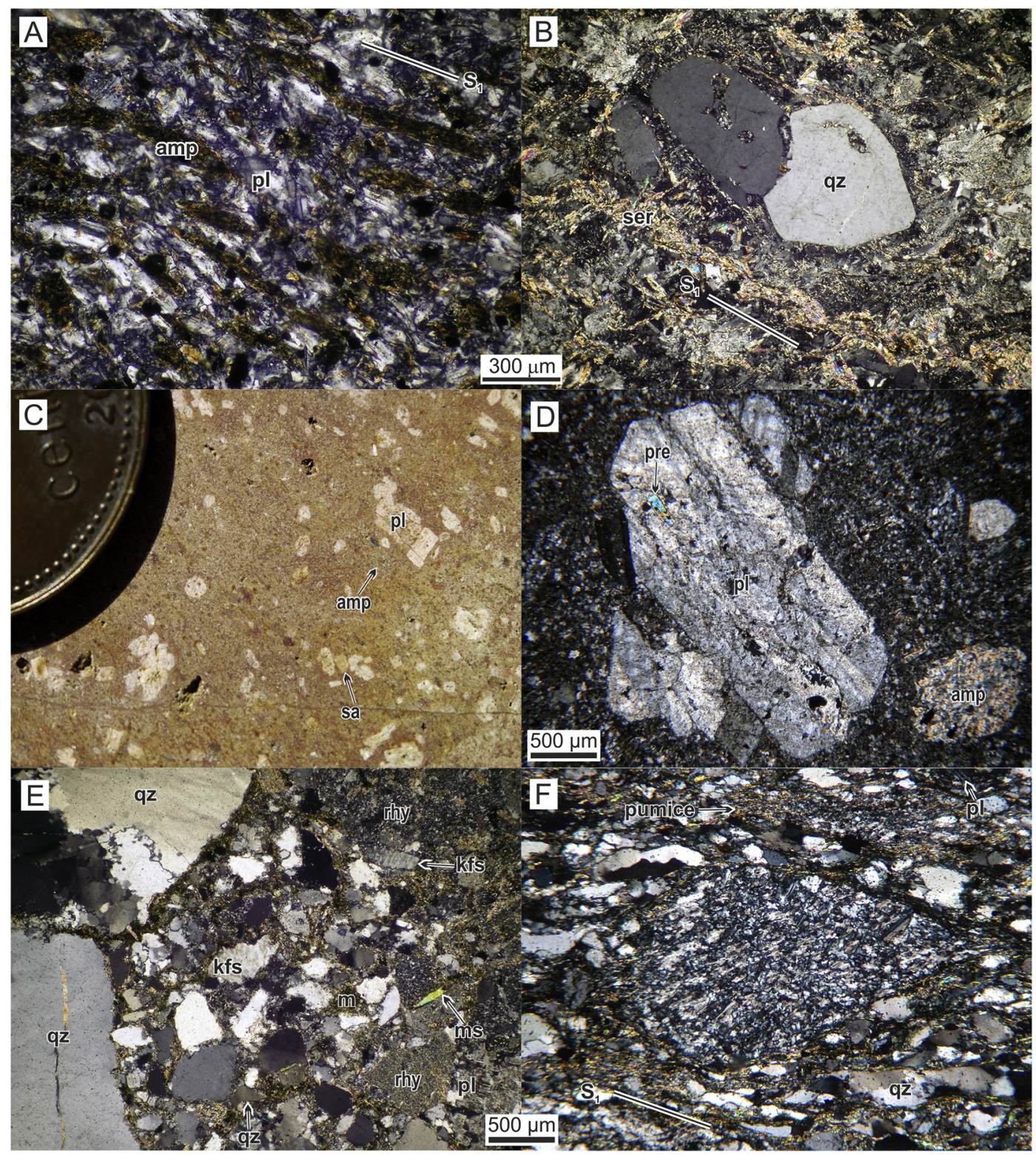

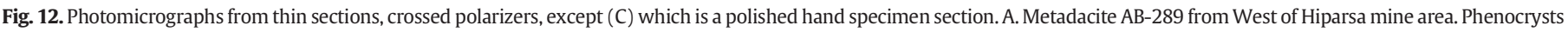

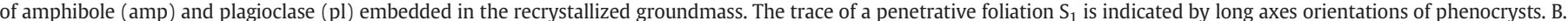

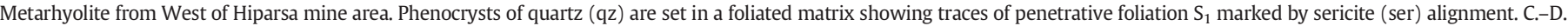

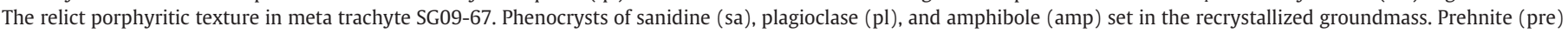

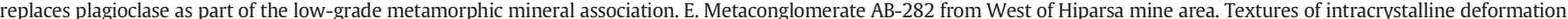

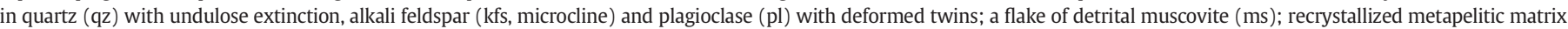

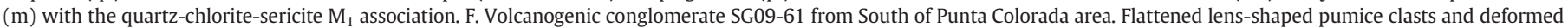

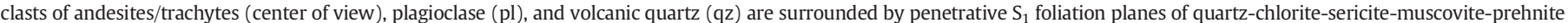
$\mathrm{M}_{1}$ association.

defines slaty cleavage $S_{1}$ of the meta-K-bentonite. This mineral association is characteristic of low-grade $\mathrm{M}_{1}$ regional metamorphism (Spear, 1995).

The arkosic pumice sandstones which are interbedded with $\mathrm{K}$ bentonite also reveal a main volcano-pyroclastic provenance. They are composed of lens-shaped pumice clasts now recrystallized to sericite + albite, abundant microcline $>$ plagioclase, and lithic fragments of andesites and granophyres. The matrix is recrystallized to very finegrained aggregates of sericite and albite.

In Arroyo Salado creek, at Mussi farm, the K-bentonite SG12-06 consist mainly of fragments of quartz phenocrysts with minor plagioclase and other feldspars, and sub-rounded devitrified pumice clasts (Fig. 13 B, D, F). Euhedral flakes of biotite are also present as phenocrysts (Fig. 13 E). Long-prisms of zircon crystals with axial ratios up to 4:1 and oscillatory zoning are present (Fig. $13 \mathrm{D}$, see also Section 6), both features consistent with their magmatic origin. The primary glassy matrix of this K-bentonite is also devitrified and recrystallized as that of AVS-3. $S_{1}$ slaty cleavage is marked by alignment of very fine-grained aggregates of sericite, clay minerals, zeolites, and prehnite which is also characteristic of low-grade regional metamorphism $\mathrm{M}_{1}$ under subgreenschist facies. Coffin-shaped zeolite porphyroblasts $(\leq 100 \mu \mathrm{m}$ long) also indicate this metamorphic grade (Fig. $13 \mathrm{E}$ ).

In the León farm of the Arroyo Salado creek, as key pyroclastic features, metaignimbrite SG09-75 display fine-grained euhedral phenocrysts of quartz and plagioclase. The quartz is embayed and contains inclusions of fresh biotite and devitrified matrix. Perthitic feldspar displays a granophyric arrangement with quartz (Fig. $13 \mathrm{G}$ ), while plagioclase is normally zoned and also show sericite-rich cores and rims 


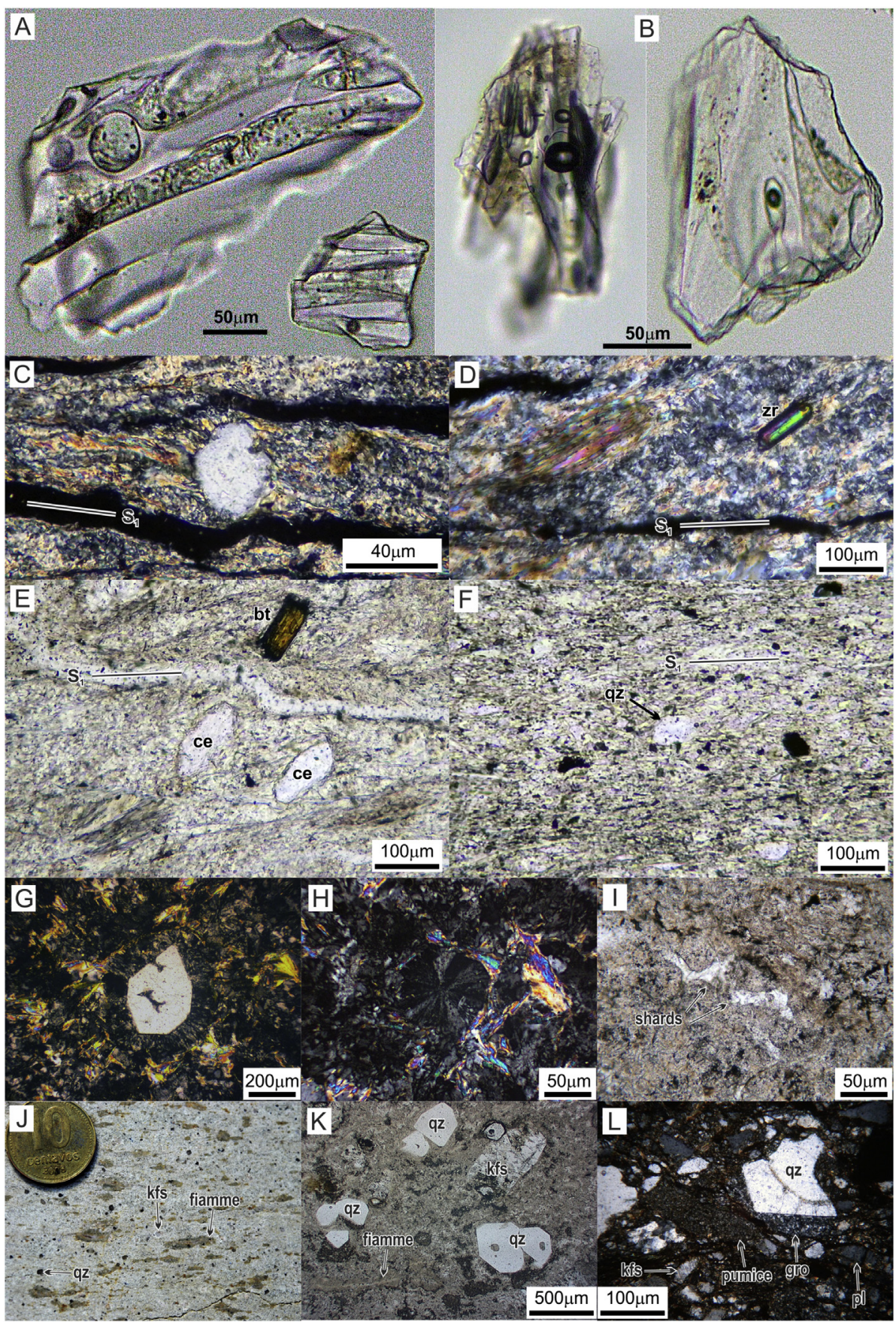

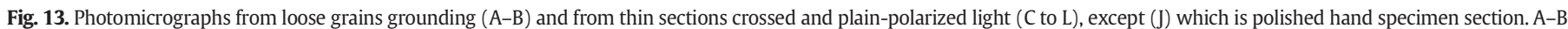

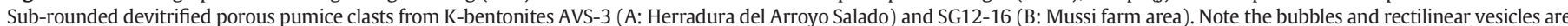

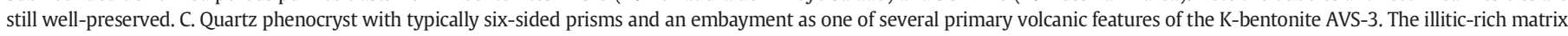

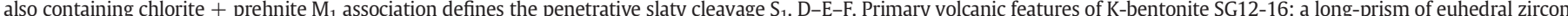

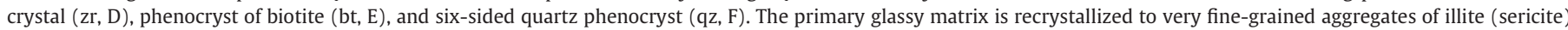

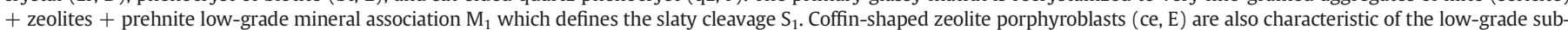

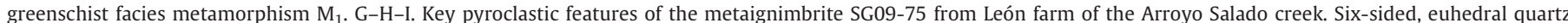

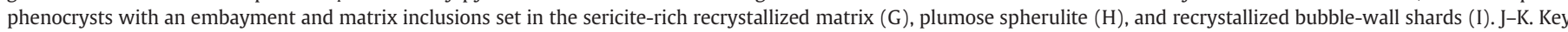

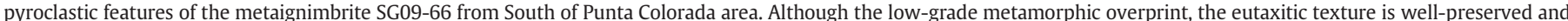

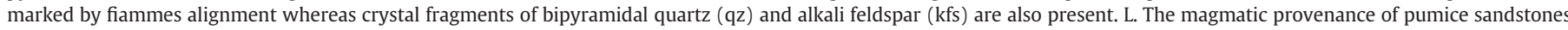

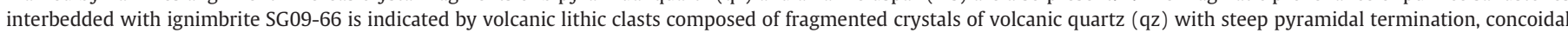
fracture and felsitic groundmass (gro), lens-shaped and flattened pumices, and angular fragments of alkali feldspar (kfs) and plagioclase (pl) crystals.

replaced by albite. Apatite and zircon are accessories. Glassy fragments such as pumice and bubble-wall shards are now devitrified and recrystallized into spherical and plumose spherulites or even metamorphic mineral assemblages (Fig. $13 \mathrm{H}, \mathrm{I}$ ). Phenocrysts are embedded in a felsitic, very fine-grained matrix which is recrystallized to a metamorphic assemblage of sericite, prehnite, and chlorite. By relict igneous phenocrysts, the ignimbrite can be classified as rhyolitic (see also geochemical features in Section 6).

The pumice sandstones interbedded with metaignimbrite are volcanogenic rocks according to volcanic lithic clasts, angular quartz and K-feldspars (anorthoclase, microcline), and devitrified pumice and glass shards (Fig. $13 \mathrm{~L}$ ). It resembles the same rocks as those arkosic 
pumice sandstones from the Herradura del Arroyo Salado. Fragments of volcanic quartz with pyramidal termination are attached to groundmass of felsitic texture while lens-shaped and flattened pumices are devitrified/recrystallized to sericite. K-feldspars with undulose extinction are replaced by groups of small flattened crystals of pumpellyite.

Meta-siltstones are also volcanogenic rocks which are intimately interbedded into the volcano-sedimentary complex. It consists mainly of fragments of angular quartz and very fine-grained $(<200 \mu \mathrm{m})$ pumice clasts embedded in a matrix which is recrystallized to sericitemuscovite and chlorite. Pumices are flattened, stretched and recrystallized to sericite and prehnite-pumpellyite, and together with the alignment of aggregates of sericite-chlorite defines slaty cleavage $S_{1}$ of metapelites. Chlorite fills cavities whereas zeolites + pumpellyite recrystallized in the necks of micro-boudins or in fibrous veinlets which cross-cut $\mathrm{S}_{1}$ cleavage as a late-stage of regional $\mathrm{M}_{1}$ metamorphism.

In a cryptodome, hyaloclastic breccia of the outer part wraps up hyaloclastic lava of the inner part. The breccia is monomictic, nonstratified and consists of angular clasts of "false granitic texture" (e.g., McPhie et al., 1993, p. 169) with a diameter of up to $15 \mathrm{~mm}$, and set in a cogenetic matrix. The hyaloclastic breccia formed by the fracturing of the coherent dome in response to cooling contraction, and shearing of the fractured dome due to movement of the growing cryptodome. The clasts consist of angular fragments of quartz, plagioclase, and biotite, and pod-like fragments of devitrified/recrystallized pumice. Plagioclase and pumice are replaced by a metamorphic association of prehnite, fibrous pumpellyite, and clay minerals. Clasts are cut by a network of fractures which is filled with goethite.

A somewhat coherent hyaloclastic lava of the inner part (sample SG12-11) is composed of devitrified vitrophyre with "false" granophyric to micro-graphic texture (e.g., McPhie et al., 1993, p. 169). Fragments of bipyramidal quartz, albitized plagioclase, and biotite with cluster cysts of prehnite, igneous amphibole, and angular pumice are all embedded in a matrix which is mainly composed of prehnite, pumpellyite, albite, and tremolite-actinolite. Closely spaced pores are also filled with this association + carbonates. This mineral association within synvolcanic intrusions may also result from reactions with seawater or modified seawater circulating through the intrusion, either during hydrothermal activity or cooling (Gifkins et al., 2005b). However, the mineral association is regionally extensive, and therefore it can also be ascribed as related to low-grade regional metamorphism $\mathrm{M}_{1}$ under greenschist facies.

In hyaloclastite intercalated between outer and inner parts of the cryptodome (Fig. 9 D), glass is devitrified in banded perlite comprising perlitic fractures which form a roughly rectilinear network. Sericite + hematite mark the relict perlitic fractures. Roughly spherical spherulites consist of radial crystal fibers which are recrystallized to albite, quartz, and sericite. Clusters of sericite mark the boundaries between spherulites. The matrix of the hyaloclastite is now composed of massive sericite + hematite, euhedral quartz, and albitized plagioclase $\pm \mathrm{K}$ feldspar.

South of Punta Colorada, in the berm of the Argentine sea coast, the metaignimbrite SG09-66 preserves relics of igneous minerals and textures such as crystal fragments of bipyramidal quartz, K-feldspar, plagioclase and rare biotite. The matrix is composed of glass shards and aligned fiammes which defines a well-preserved eutaxitic texture (Fig. $13 \mathrm{~J}, \mathrm{~K}$ ). Vitric clasts are devitrified to spherical and plumose spherulites in addition to overprinting quartz-albite-sericite association which belongs to low-grade regional metamorphism $\mathrm{M}_{1}$ under greenschist facies.

The porphyritic texture in the meta-trachyte SG09-67 consists of relatively large, euhedral plagioclase and sanidine, and minor amphibolebiotite phenocrysts dispersed in a fine-grained and recrystallized groundmass (Fig. 12 C, D). Albite + epidote + sericite replaces the plagioclase, and quartz-sericite-opaque minerals pseudomorphically overprint igneous amphibole and biotite. The groundmass is recrystallized to aligned sericite which defines the $S_{1}$ non-penetrative cleavage.

\subsection{Metaconglomerates}

The clasts of the metaconglomerate $\mathrm{AB}-282$ are sub-rounded to rounded, poorly sorted pebbles and cobbles of medium sphericity, composed of granitoids, andesites to rhyolites, mono- and polycrystalline quartz, shales and phyllites. Archeocyathan limestone clasts are minor but large (up to $1 \mathrm{~m}$ ) and subangular. Petrographic analysis indicates an essentially magmatic provenance of detrital components, with minor inputs of metamorphic and calcareous sources (Fig. $12 \mathrm{E}$ ). The same components ( \pm detrital zircon, apatite, and tourmaline) are in the matrix, in which deformation lamellae distinguish intracrystalline deformation of minerals from clasts, undulose extinction and subgrains in quartz, kinked or tapered albite twins towards the grain boundary and also undulose extinction in feldspars. Sericite + chlorite + quartz alignment marks the $S_{1}$ cleavage planes in the lepidoblastic matrix, and are typical of greenschist facies (chlorite zone) $\mathrm{M}_{1}$ metamorphism.

Limestone clasts of up to $0.25 \mathrm{~mm}$ in size, with recrystallized mantled texture, are also recognized at the microscopic scale. Mantling is composed of relict core aggregates of coarse carbonate crystals with undulose extinction and bent twins, and a fine-grained recrystallized mantle of the same composition and mostly polygonal granoblastic texture (González et al., 2011a).

Sample SG09-61 is a pebble conglomerate with sparse volcanic clasts. The metaconglomerate contains clasts of quartz (undulose extinction and sub-grains), plagioclase and heavy minerals (zircon, apatite, rutile, and opaque). Its magmatic provenance of detrital components is also revealed by sub-rounded to rounded pebbles of andesites, trachytes, and trachyandesites, devitrified pumice and minor granitoids (Fig. 12 F). Clasts share the same composition as that of the trachyte SG09-67 (see above) which is intercalated in the same sequence of the metaconglomerate. Six-sided crystals also indicate the volcanogenic origin of quartz grains with embayments and rounded inclusions of the groundmass. The granolepidoblastic matrix consists of recrystallized quartz + chlorite + sericite + muscovite + prehnite + pumpellyite, which define the $S_{1}$ cleavage planes together with lensshaped and flattened pumice clasts. The mineral association is also typical of prehnite-pumpellyite facies $\mathrm{M}_{1}$ metamorphism.

\subsection{Clay mineralogy of K-bentonites}

\subsubsection{Meta-K bentonite AVS-3}

In XRD analysis of whole-rock powder, this sample is composed predominantly of quartz, sericite, and feldspars, in accordance to those seen in petrography (Fig. $14 \mathrm{~A}$ ). Plagioclase and alkali feldspars were possible to recognize as the varieties of feldspars. Overall in whole-rock powder, feldspars have many reflections that interfere with other minerals, such as zeolites, apatite, carbonates, among others, roughly in the range between 27 and $31^{\circ} 2 \Theta$ (Moore and Reynolds, 1997). Due to this interference, the zeolites recognized under thin sections were difficult to identify with XRD. Although sericite is noticeable as a major component, its sharp peak near $26.5^{\circ} 2 \ominus$ (60.63\% intensity, Tomita et al., 1998) is overlapped with quartz.

In the air-dried sample, the clay mineral fraction show sharp peaks at $10.001,5.01$, and $3.33 \AA$ indicating a predominantly illite phase (Fig. 14 C, Huff, 2016). Ethylene glycol (EG) solvation has not caused significant changes in the diffraction pattern (10.069, 5.01 and $3.33 \AA$ ), and thus almost pure illite is present without I/S component (Moore and Reynolds, 1997). However examined in detail, EG solvation has produced a weak, broad and bell-shaped reflection near $5^{\circ} 2 \Theta(d=$ $17.391 \AA$ ) which indicates a small amount of smectite (Moore and Reynolds, 1997). Upon heating to $550{ }^{\circ} \mathrm{C}-2 \mathrm{~h}$, the diffraction pattern is not changed and resembles a pure illite composition with a sharp peak at 10.069 A. Kaolinite is present as a minor constituent of clay fraction (Fig. $14 \mathrm{C}$ ). In the air-dried sample, kaolinite is noticeable by weak but sharp peaks near $12.35^{\circ} 2 \Theta(100 \%$ intensity, $d=7.151)$ and $24.9^{\circ} 2 \Theta$ 

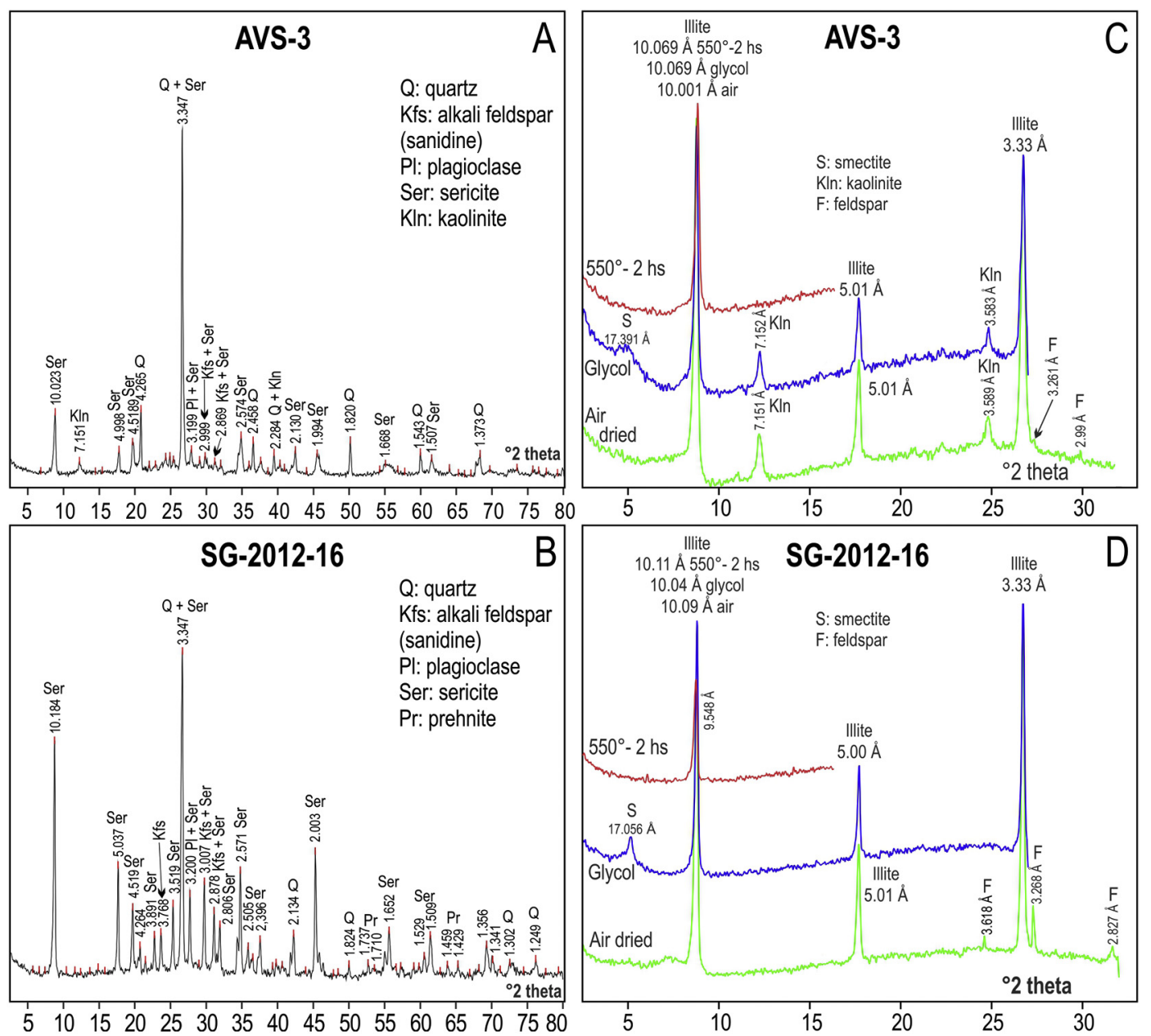

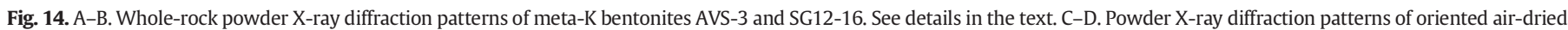

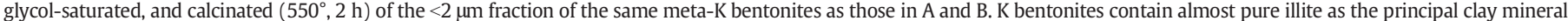
resulting by metamorphism. Minor smectite and kaolinite are also present as secondary clay minerals derived by alteration from feldspars.

(61\%, $d=3.589 \AA ̊$; $2 \Theta$ and intensities after Bish and Von Dreele, 1989). EG solvation has not caused changes in the diffraction pattern whereas, after heat treatment to $550{ }^{\circ} \mathrm{C}$, the peak at $12.35^{\circ} 2 \theta$ disappears given that kaolinite become amorphous to X-rays after heating to this temperature (Poppe et al., 2000).

The peaks near $27^{\circ} 2 \theta(3.261 \AA)$ and $30^{\circ} 2 \theta(2.99 \AA)$ indicate that some variety of feldspars is present as a very fine-grained fraction (Moore and Reynolds, 1997).

\subsubsection{Meta-K bentonite SG-2012-16}

Whole-rock XRD analysis shows that it consists of sericite, quartz, alkali feldspar (sanidine), and plagioclase, in agreement to those seen in petrography (Fig. 14 B). Alkali feldspars are noticeable through many reflections. Sanidine is visible as a primary volcanic feature of this Kbentonite by a sharp peak at $29.78^{\circ} 2 \Theta(d=3.007$, Moore and Reynolds, 1997). Nevertheless, their identification comes only from this single peak which is also a reflection partially overlapping with the peak in this position for the sericite. Thus, sanidine is a minor component in the alkali feldspar varieties of this sample.

Prehnite appears as a minor constituent with peaks at 43.69 (4\%), 52.5 (16.6\%), 53.3 (46.76\%), and $64.99^{\circ} 2 \Theta(4.51 \%, 2 \Theta$ and intensities after Downs et al., 1993). The most intense peaks for prehnite are also interfered by feldspars (Fig. 14 B). Sharp peaks for sericite but of low intensity, are noticeable near $35.48^{\circ} 2 \theta(2 \%)$ and $45^{\circ} 2 \theta(12.15 \%$, Tomita et al., 1998). The peak near $26.5^{\circ} 2 \Theta$ overlapping with quartz is also present.
In the air-dried sample, the clay fraction of K-bentonite SG-12-16 is also composed predominantly of pure illite, with the main basal reflections at $10.09 \AA$, $5.01 \AA$ and $3.33 \AA$ (Fig. 14 D). As that in AS-3, EG solvation and heating to $550{ }^{\circ} \mathrm{C}-2 \mathrm{~h}$ has not caused significant changes in the diffraction pattern ( 10.04 and 10.11 Å respectively) confirming the pure illite phase, but smectite is also present as a minor component of the clay fraction $\left(\sim 5^{\circ} 2 \Theta, d=17.056 \AA\right)$. The peaks near $24.9^{\circ} 2 \Theta(3.618$ $\AA$ ), $27^{\circ} 2 \Theta(3.268 \AA)$, and $32^{\circ} 2 \Theta(2.827 \AA$ ) indicate that some variety of feldspars is present as a very fine-grained fraction (Moore and Reynolds, 1997).

\subsubsection{Illite crystallinity of meta-K bentonites}

The crystallinity of illite is frequently used as an indicator of the metamorphic grade in clay-bearing rocks metamorphosed under conditions between diagenesis and low-grade metamorphism (Frey and Robinson, 1999). Thus, measurements of the Kübler index were carried out in both K-bentonites, taking into account that samples analyzed are rich in illite. It is assumed that all the original smectite formed by devitrification of vitroclasts was transformed into illite during metamorphism. Kübler index measurements yielded 0.24 (AVS-3) and 0.25 (SG-12-16) $\Delta^{\circ} 2 \theta$, indicating that regional metamorphism which affected meta-Kbentonites is within the greenschist facies field (cf. Merriman and Peacor, 1999), as is corroborated by petrographic analysis.

On the other hand, minor smectite and kaolinite constituents are interpreted as secondary minerals formed from feldspar alteration during weathering of the meta- $\mathrm{K}$ bentonites. 


\section{U-Pb zircon geochronology}

Six samples were selected for zircon study by MC-ICPMS-LA and SHRIMP U-Pb methods to constrain the timing of protoliths sedimentation and magmatic crystallization of the El Jagüelito Formation. Sample locations are shown in Fig. 2 whereas GPS and applied methods are in Tables 1 and 2. Standard procedures for zircon separation/mounting and analytical conditions of the U-Pb methods are summarized in the Supplementary materials.

Two out of six samples are meta-conglomerates (AB-282 and SG0961) which were preferred for the U-Pb zircon analysis because of their magmatic provenance of detrital components and since they are intercalated with the igneous rocks within the same sequence. The other four samples, two are K-bentonites (SG12-16 and AVS-3), and two are ignimbrites (SG09-66 and SG09-75).

\subsection{Results}

Full U-Pb analytical results are presented in Tables 1, 2, and 3 of the Supplementary materials and illustrated in Figs. 15, 16 and 17. The crystallization and depositional ages are summarized in Tables 1 and 2.

\subsubsection{Meta-K bentonite SG12-16}

The analyzed volcanic zircons are bipyramidal with well-defined faces to euhedral prismatic (aspect ratio 2:1 to 3.1) and their lengths range from 90 to $150 \mu \mathrm{m}$ (some exceptionally $200 \mu \mathrm{m}$ ). The backscattered imaging of the grains shows well-developed oscillatory and sector zoning that along morphology and high Th/U values are typical magmatic features. 39 out of 44 analyzed zircons have concordant ages of $<10 \%$ discordance.

A cluster of fifteen concordant zircons yielded a weighted ${ }^{206} \mathrm{~Pb} /{ }^{238} \mathrm{U}$ mean age of $515.6 \pm 2.2 \mathrm{Ma}$ (MSWD 2.5, Fig. $15 \mathrm{~A}$ ). Therefore, we interpret the age as the magmatic crystallization of the K-bentonite. One of the remaining zircon grains has a younger ${ }^{206} \mathrm{~Pb} /{ }^{238} \mathrm{U}$ age of $487 \pm$ $3 \mathrm{Ma}$ which can be interpreted as $\mathrm{Pb}$ loss probably due to Ordovician regional metamorphism and deformation. There are four inheritance ages of $581,672,1002$ and 1120 Ma.

\subsubsection{Meta-K bentonite AVS-3}

Zircon crystals are short prisms and fragments with axial ratios up to $2: 1$, while few grains are equant, and lengths minor and around $100 \mu \mathrm{m}$. CL images show generally bright luminescence and oscillatory zoning. The $U$ content is mostly between 101 and 312 ppm, and Th/U ratios are between 0.35 and 1.12, a characteristic consistent with their magmatic origin (Hoskin and Schaltegger, 2003).

17 spots in 17 crystals were analyzed. The ages show a low degree of concordance as depicted in the Tera Wasserburg diagram of Fig. 15 B. Therefore, the best age is calculated as a weighted ${ }^{206} \mathrm{~Pb} /{ }^{238} \mathrm{U}$ mean age of 8 spots, with $532.9 \pm 3.9 \mathrm{Ma}$ (MSWD 9.1), excluding 4 inherited and highly discordant ages. We interpret the weighted mean age as the magmatic crystallization of the K-bentonite. One zircon grain has a younger ${ }^{206} \mathrm{~Pb} /{ }^{238} \mathrm{U}$ age of $474 \pm 28 \mathrm{Ma}$ which can be interpreted as $\mathrm{Pb}$ loss due to Ordovician regional metamorphism and deformation. The remaining zircons show inheritance ages in the range 551-956 Ma and single ages of 1408 and $1848 \mathrm{Ma}$.

\subsubsection{Metaignimbrite SG09-75}

20 spots were analyzed from 19 crystals, of which the most are short prisms and fragments with axial ratios up to $2: 1$, while few grains are equant. In the Wetherill diagram (Fig. $16 \mathrm{~A}$ ) it can be seen that the spots scatter with a variable degree of discordance, showing disturbance by $\mathrm{Pb}$ loss and inheritance. The four spots more consistent and close to the Concordia curve define an age of 529.4 \pm 8.4 Ma (MSWD 2.4), which is the best date that can be derived and therefore considered the crystallization age of the ignimbrite. A younger cluster of 5 spots ( 2 outer zones of crystals) defines a mean age of $445 \pm 15 \mathrm{Ma}$ (MSWD 5.4) which is considered as $\mathrm{Pb}$ loss due to the onset of exhumation for this rock, after peak metamorphism-deformation in Early Ordovician. The three youngest spots in the surroundings of 400 Ma correspond to outer zones of crystals and are considered as also resulting from $\mathrm{Pb}$ loss. The remaining eight spots are zircons inherited from sources which ages range between 588 and $1071 \mathrm{Ma}$ (Fig. 16 B).

\subsubsection{Metaignimbrite SG09-66}

Ten crystals ( 12 spots) were analyzed, with dominant prisms and fragments with an axial ratio up to 2:1, and minor crystals more equant (Fig. 16 D). Some crystals are fractured, while some others show dark inclusions into inner zones. The degree of age concordance is very poor, and therefore the age is spurious without geological meaning (Fig. 16 C). Nevertheless, two least discordant spots but with high error yielded younger ${ }^{207} \mathrm{~Pb} /{ }^{206} \mathrm{~Pb}$ ages of 511 and $623 \mathrm{Ma}$, and also correspond to outer zones of crystals. It is a highly discordant age. However, the $511 \mathrm{Ma}$ is considered as the timing of magmatic crystallization of the ignimbrite. Although this interpretation is rather speculative, the ignimbrite is interbbeded in the same volcano-sedimentary sequence of the metaconglomerate SG09-61 which has a Cambrian depositional age (see below).

\subsubsection{Metaconglomerate $A B-282$}

The analyzed detrital zircons are rounded to sub-rounded prisms between 100 and $350 \mu \mathrm{m}$ of length. The backscattered imaging of the grains shows well-developed oscillatory zoning that indicates magmatic origins. The total of 39 zircon grains yielded concordant ages $(<10 \%$ discordance, Fig. $17 \mathrm{~A}$ ). The zircon age distribution pattern is essentially unimodal (Fig. $17 \mathrm{~B}$ ). The main peak is at $526 \mathrm{Ma}$, with the significant spread of ages between 501 and $623 \mathrm{Ma}$. A cluster of seven youngest concordant zircons that contribute to the $526 \mathrm{Ma}$ age probability peak yielded a mean ${ }^{206} \mathrm{~Pb} /{ }^{238} \mathrm{U}$ age of $510 \pm 24$ Ma (MSWD 0.032 , Fig. 17 E) which we consider as the maximum depositional age of the conglomerate. This age is in the range of likely crystallization ages reported here for the interbedded pyroclastic rocks, and thus we also interpret the $510 \pm 24 \mathrm{Ma}$ as the age of the igneous source from which zircons were derived. Three single grains with Ordovician ages yielded a mean ${ }^{206} \mathrm{~Pb} /{ }^{238} \mathrm{U}$ age of $479 \pm 35 \mathrm{Ma}$ (MSWD 0.085) which is interpreted as $\mathrm{Pb}$ loss due to regional metamorphism-deformation. There is a range of older ages from 846 to $1169 \mathrm{Ma}$, but without a notable peak. The remaining zircon grains have younger ${ }^{206} \mathrm{~Pb} /{ }^{238} \mathrm{U}$ ages of 391 and $429 \mathrm{Ma}$ which could be interpreted as recent $\mathrm{Pb}$ loss.

\subsubsection{Metaconglomerate SG09-61}

In transmitted light microscopy images, the zircons from this metaconglomerate are bi-pyramidal to prismatic (aspect ratio 2:1) and rounded to sub-rounded prisms (aspect ratio 1:1), amber color to

Table 1

Synthesis of the U-Pb zircon magmatic crystallization ages of the pyroclastic rocks from the El Jagüelito Formation. See locations of the samples in Fig. 2.

\begin{tabular}{|c|c|c|c|c|c|}
\hline Sample & GPS (S-W) & Locality & Rock type & Method & Age (Ma) \\
\hline SG09-66 & $41^{\circ} 45^{\prime} 20^{\prime \prime}-65^{\circ} 00^{\prime} 18^{\prime \prime}$ & South of Punta Colorada & Rhyolitic ignimbrite & LA-ICPMS & $\mathrm{Pb}$ loss \\
\hline SG09-75 & $41^{\circ} 35^{\prime} 03^{\prime \prime}-65^{\circ} 02^{\prime} 44^{\prime \prime}$ & Arroyo Salado creek at León & Rhyolitic ignimbrite & LA-ICPMS & $529.4 \pm 8.4$ \\
\hline SG12-16 & $41^{\circ} 34^{\prime} 42^{\prime \prime}-65^{\circ} 05^{\prime} 02^{\prime \prime}$ & Arroyo Salado creek at Mussi & Dacitic K-bentonite & SHRIMP & $515.6 \pm 2.2$ \\
\hline AVS-3 & $41^{\circ} 28^{\prime} 39^{\prime \prime}-65^{\circ} 20^{\prime} 04^{\prime \prime}$ & Herradura del Arroyo Salado & Dacitic K-bentonite & SHRIMP & $532.9 \pm 7.3$ \\
\hline
\end{tabular}


Table 2

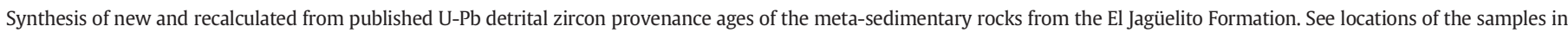
Fig. 2.

\begin{tabular}{|c|c|c|c|c|c|c|}
\hline \multirow[t]{2}{*}{ Sample } & \multirow[t]{2}{*}{ GPS (S-W) } & \multirow[t]{2}{*}{ Locality } & \multirow[t]{2}{*}{ Rock type } & \multirow[t]{2}{*}{ Method } & \multicolumn{2}{|l|}{ Age (Ma) } \\
\hline & & & & & Youngest peak & $\overline{\text { Youngest zircons }^{\mathrm{a}}}$ \\
\hline SG09-61 & $41^{\circ} 45^{\prime} 14^{\prime \prime}-65^{\circ} 00^{\prime} 35^{\prime \prime}$ & South of Punta Colorada & Meta-conglomerate & LA-ICPMS & 533 & $515.8 \pm 8.7$ \\
\hline AB-282 & $41^{\circ} 39^{\prime} 02^{\prime \prime}-65^{\circ} 25^{\prime} 15^{\prime \prime}$ & West of Sierra Grande & Meta-conglomerate & LA-ICPMS & 526 & $510 \pm 24^{b}$ \\
\hline SG05-3 & $41^{\circ} 32^{\prime} 28^{\prime \prime}-65^{\circ} 10^{\prime} 43^{\prime \prime}$ & Arroyo Salado creek & Meta-greywacke & LA-ICPMS & 556 & $533 \pm 26^{\mathrm{b}}$ \\
\hline SGR-018 & $41^{\circ} 34^{\prime} 43^{\prime \prime}-65^{\circ} 05^{\prime} 18^{\prime \prime}$ & Arroyo Salado creek & Meta-sandstone & SHRIMP & 535 & $515.5 \pm 5.5^{c}$ \\
\hline
\end{tabular}

${ }^{\mathrm{a}}$ Number of grains: SG09-61 = 6; AB-282 = 7; SG05-03 = 6; SGR-18 = 5 .

b Recalculated from Naipauer et al. (2010).

c Recalculated from Pankhurst et al. (2006).

colorless and their lengths range from 10 to $100 \mu \mathrm{m}$, with minor crystals of up to $200 \mu \mathrm{m}$ (Fig. 17 C). Bi-pyramidal to prismatic zircon morphologies are typical of igneous sources. The magmatic provenance of detrital components is revealed by pebbles of andesites, trachytes, trachyandesites, pumice, and granitoids (Fig. 12 F), also corroborated by these zircon morphologies. The total of 39 zircon grains yielded concordant ages of $<10 \%$ discordance (Fig. $17 \mathrm{C}$ ). The sample has a bimodal age distribution (Fig. $17 \mathrm{D}$ ). One main peak is at $533 \mathrm{Ma}$, with slightly older one at $555 \mathrm{Ma}$. The second main population is at $990 \mathrm{Ma}$, with the spread of ages between 878 and $1057 \mathrm{Ma}$. There are two single ages of 1891 and $2638 \mathrm{Ma}$. A cluster of six younger concordant zircons that contributes to the $533 \mathrm{Ma}$ age peak yielded a ${ }^{206} \mathrm{~Pb} /{ }^{238} \mathrm{U}$ mean age of $516 \pm 9 \mathrm{Ma}$ (MSWD 0.97, Fig. $17 \mathrm{~F}$ ) which we consider as the maximum depositional age of the conglomerate. This age is in the range of likely 530-515 Ma crystallization ages reported here for the interbedded pyroclastic rocks, and thus we also interpret the $516 \pm 9 \mathrm{Ma}$ as the age of the igneous source from which zircons were derived.

\subsection{Hf isotopes in zircons}

Dated detrital zircon grains from metaconglomerate SG09-61 were investigated for Hf-isotope compositions (Table 3 of the ESM). Zircons in the 507-600 Ma interval have relatively crustal Hf isotopic composition ( $\varepsilon \mathrm{Hft}$ from -0.83 to -3.81 , with one value of +3.16 ; Fig. $18 \mathrm{~A}$ ), indicating that the magma source of the Cambrian volcanogenic detrital components was derived from the crustal material. The Hf $\mathrm{T}_{\mathrm{DM}}$ model ages indicate separation from the mantle at c. $1540 \mathrm{Ma}$ (average of 8 $\mathrm{T}_{\mathrm{DM}}$ ages, Table 3 of the ESM, Fig. $18 \mathrm{~B}$ ).

Zircons in the range of 1035-1114 Ma have juvenile Hf isotopic composition with $\mathrm{\varepsilon Hft}$ from +1.73 to +9.38 with one value of -3.78 (Fig. 18 A) indicating a depleted mantle origin for most of these "Grenville-age" detrital zircons. With one exception of $2045 \mathrm{Ma}$, these zircons have mantle-derived $\mathrm{Hf}_{\mathrm{DM}}$ model ages of c. $1500 \mathrm{Ma}$ (Fig. $18 \mathrm{~B}$ ).

The two oldest detrital zircons grains with ages of 1891 and $2638 \mathrm{Ma}$ also have crustal $\mathrm{EHft}$ values of -0.17 and -2.19 , and $\mathrm{Hf} \mathrm{T}_{\mathrm{DM}}$ model ages of 2499 and 3199 Ma respectively (Fig. 18 A, B). This Hf-isotope composition of zircons indicates the presence of recycled older crustal material in the source region of the metaconglomerate SG09-61.

\section{Geochemistry}

Whole-rock powders of seven selected samples for geochemical analyses were prepared at Centro de Investigaciones Geológicas (UNLP-CONICET) using standard jaw-crushing and rings-mill. Six out of the seven samples are the same as those dated in this contribution (Table 1). Samples were sent to ACTLABS and ACMELABS (Canada), for whole-rock major and trace element analyses using lithoborate fusion and ICP abs ICP-MS methods. The localities of the analyzed samples are shown in Fig. 2 and Table 1. The full data set for whole rock analytical results are summarized in Table 4 of the Supplementary materials. Major elements data used in geochemical diagrams were recalculated to $100 \%$ on an anhydrous basis.

Although some of the major and trace elements such as $\mathrm{Cs}, \mathrm{Rb}, \mathrm{Sr}$, and $\mathrm{Ba}$ are known to be mobile under regional metamorphism, and also weathering and hydrothermal alteration, the REEs, HFSE (such as $\mathrm{Ti}, \mathrm{Y}, \mathrm{Zr}, \mathrm{Nb}, \mathrm{Hf}$ and $\mathrm{Ta}$ ), Th, Sc, V, Cr, and Ni are thought to remain relatively immobile during a wide range of metamorphic conditions (Pearce and Norry, 1979; Wood et al., 1979; Ludden et al., 1982; Hastie et al., 2007). Thus, mainly immobile elements were used here to characterize the geochemical features of the metamorphosed volcanic and pyroclastic rocks of the El Jagüelito Formation. It is noteworthy that the Winchester and Floyd (1977) and Hastie et al. (2007) diagrams are
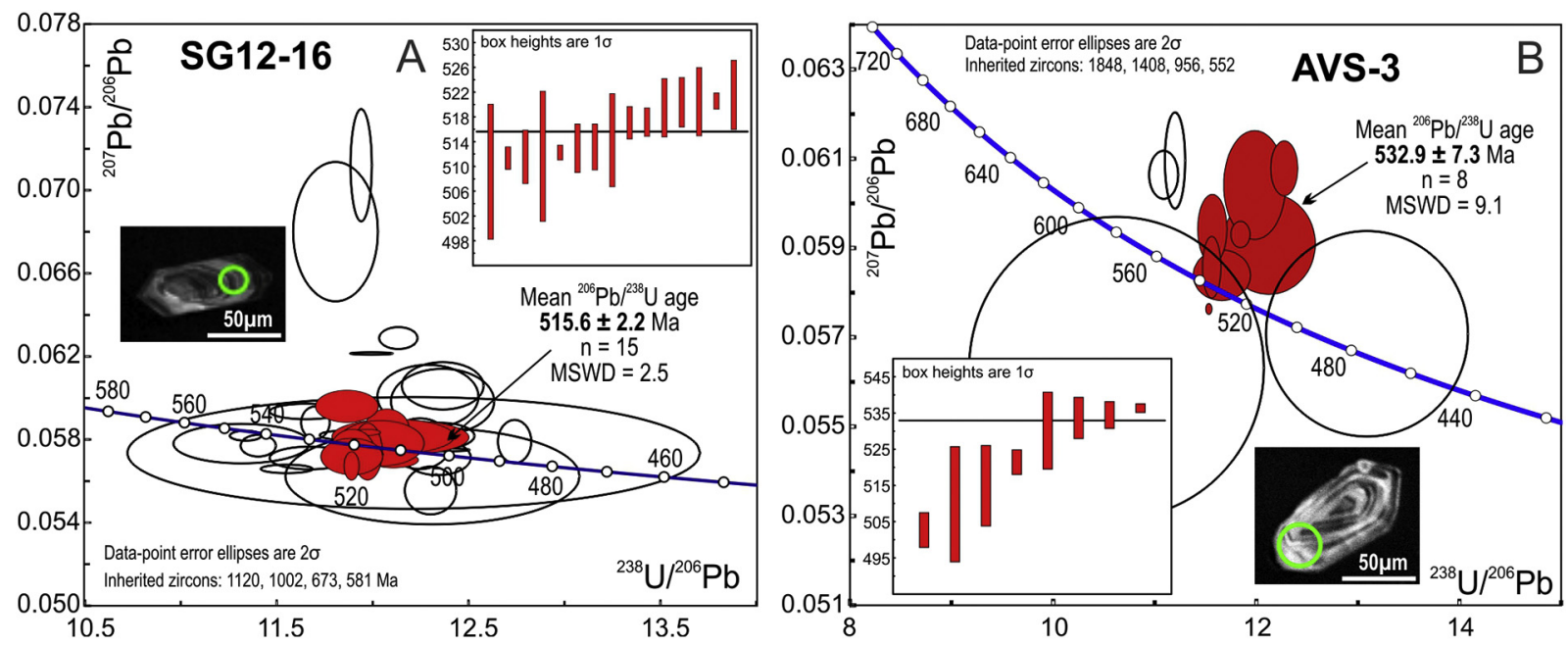

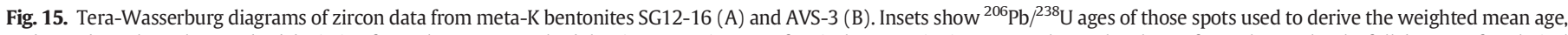

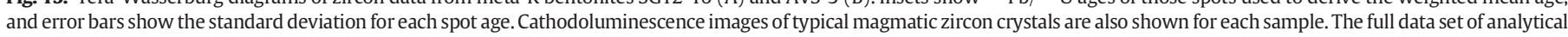
results is available in Table 2 of the Supplementary material. See locations of the samples in Fig. 2. 

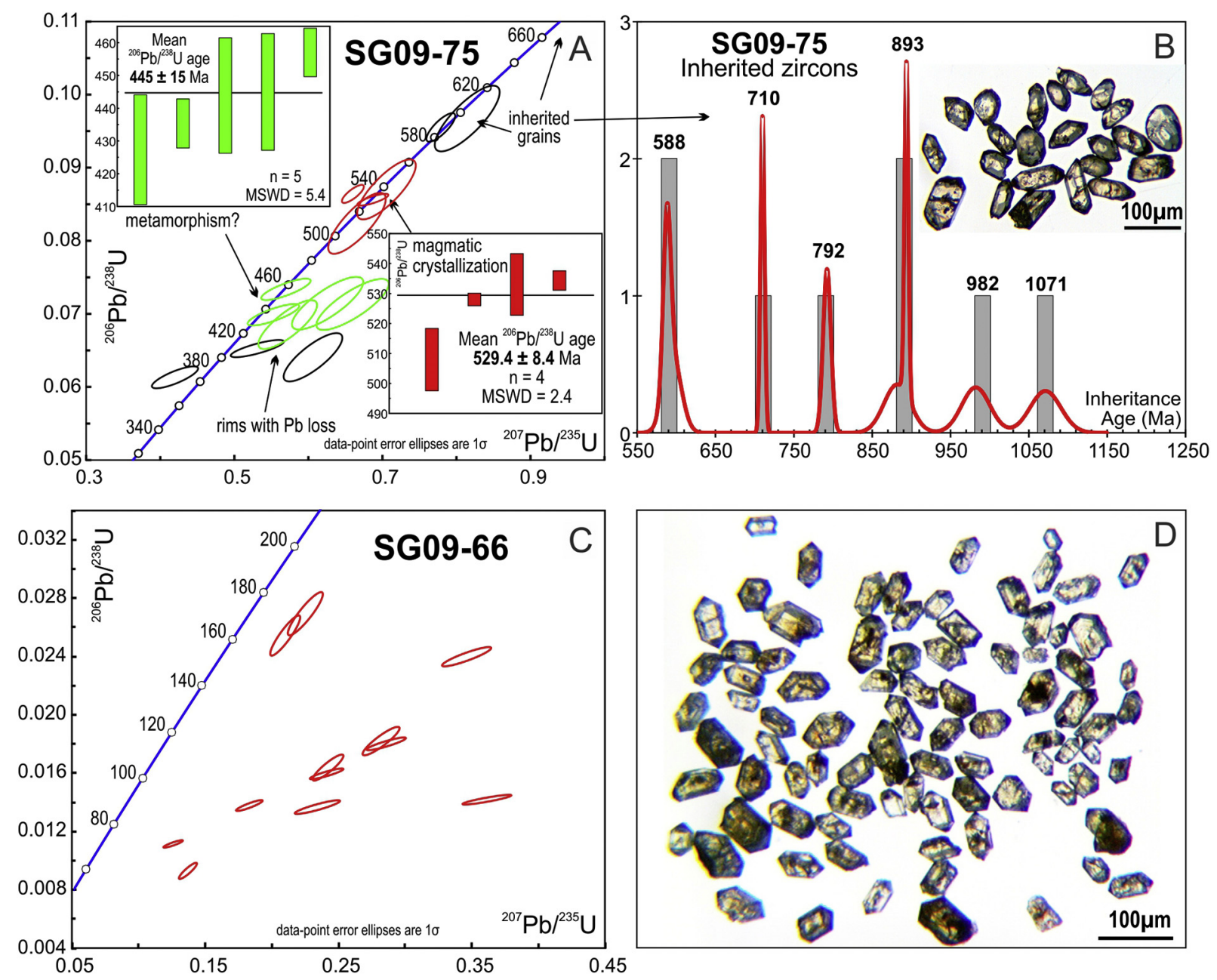

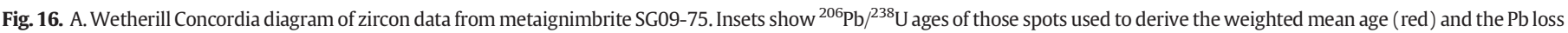

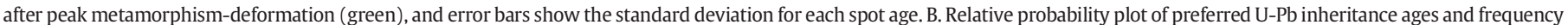

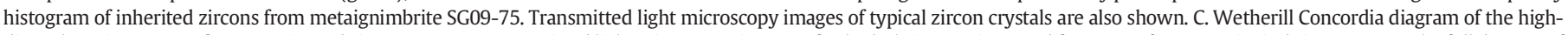

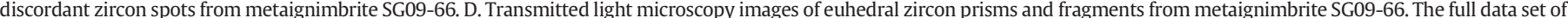

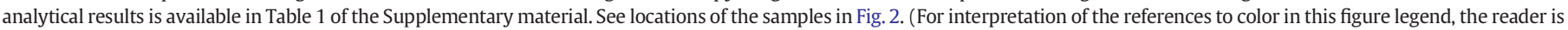
referred to the web version of this article.)

ideal for weathered and metamorphosed rocks as these plots use immobile trace elements.

In the Winchester and Floyd (1977) diagram, both K-bentonites and the lava flow/sill AB-289 $\left(\mathrm{SiO}_{2}=71.22 \%\right)$ are classified as subalkaline dacites whereas the ignimbrites SG09-75 and SG09-66 plot within the subalkaline rhyolite and peralkaline rhyolite (comendite/pantellerite) fields respectively (Fig. $19 \mathrm{~A}$ ). The $\mathrm{Nb} / \mathrm{Y}$ and $\mathrm{Zr} / \mathrm{TiO}{ }_{2}$ ratios of the lava flow SG09-67 $\left(\mathrm{SiO}_{2}=73.31 \%\right)$ and the cryptodome SG12-11 $\left(\mathrm{SiO}_{2}=\right.$ $70.17 \%$ ) are transitional to the subalkaline dacite field.

The $\mathrm{SiO}_{2}$ content of SG09-75 (76.76\%) and SG09-66 (79.73\%) are high indicating that they are high-silica rhyolitic ignimbrites. Although both rocks can be classified as peralkaline comenditic rhyolites or commendites according to the method of Macdonald (1974; $\mathrm{Al}_{2} \mathrm{O}_{3}>$ $\left.\left(1.33 \times \mathrm{FeO}^{\mathrm{T}}\right)+4.4\right)$, they are not peralkaline rocks because they do not contain phenocrysts of alkali pyroxene/amphibole, its peralkaline index (P.I. $=$ mol Na $2 \mathrm{O}+\mathrm{K}_{2} \mathrm{O} / \mathrm{Al}_{2} \mathrm{O}_{3}$, Le Maitre, 2002, see Table 4 of the ESP) is $<1.0$ and they are not strongly enriched in REEs-HFS elements. According to Leat et al. (1986), the Zr content can be used to classify the high-silica rhyolites into subalkaline (low-Zr $<300 \mathrm{ppm}$ ) and peralkaline (high-Zr $>350 \mathrm{ppm}$ ) series. The $\mathrm{Zr}$ content of the highsilica rhyolitic ignimbrites SG09-75 (125 ppm) and SG09-66 (128 ppm) is $<300 \mathrm{ppm}$, indicating that these rocks were part of a subalkaline volcanic series.
The $\mathrm{SiO}_{2}$ and $\mathrm{K}_{2} \mathrm{O}$ contents of the K-bentonites are $52.78-9.83 \%$ for SG12-16 and 67.15-6.14\% for AVS-3 whereas the $\mathrm{Al}_{2} \mathrm{O}_{3}$ contents are $29.74 \%$ (SG12-16) and 20.62\% (AVS-3). Their $\mathrm{K}_{2} \mathrm{O}$ contents are in accordance with the potassium-rich feature of the K-bentonites; major element which is essentially contained in the nearly pure illite identified by XRD analyses. In SG12-16, the $\mathrm{SiO}_{2}$ content is low for a dacite, but with regards to quartz phenocrysts as a petrographic feature and the $\mathrm{Zr} / \mathrm{TiO}_{2}$ and $\mathrm{Nb} / \mathrm{Y}$ ratios as a measure of silica differentiation and as an index of alkalinity respectively (Winchester and Floyd, 1977), this Kbentonite was derived from a felsic dacitic subalkaline magma rather than a more primitive one.

The major element geochemistry of bentonites is a particular issue that should be treated with care since these rocks come from alteration of ash fall layers under sea water in a marine environment. Seawater leaches away some of the ions during the alteration reactions that occur in subsequent diagenesis, and thus the major elements usually undergo post-depositional changes. It should be noted that the lowsilica and high-alumina contents in SG12-16 bentonite, and also in AVS-3 but to a lesser extent, seem to have been related to majorelement mobilization from diagenesis when devitrification of the volcanic ash and formation of smectite took place, to regional low-grade metamorphism that formed the illite. In this regard, the origin of gains of $\mathrm{Al}$ and $\mathrm{K}$, and loss of $\mathrm{Si}$ has been a matter of debate, and there are 

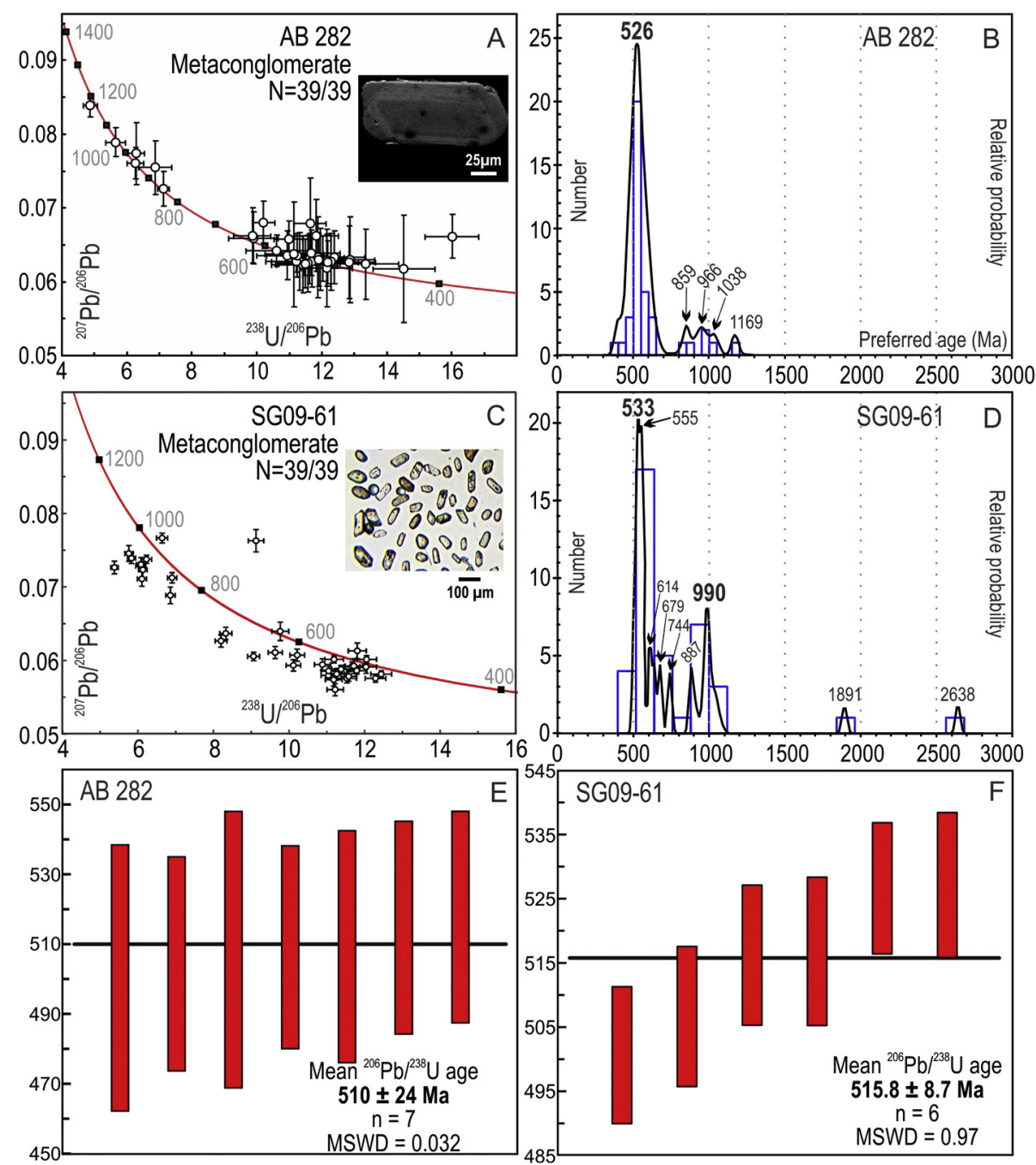

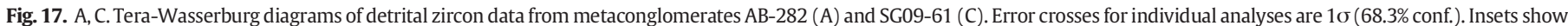

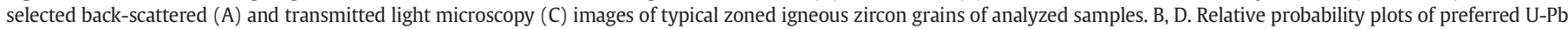

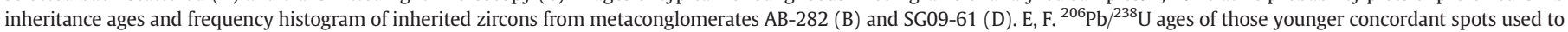

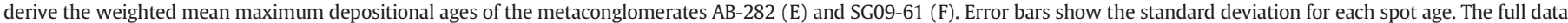
sets of analytical results are available in Table 1 of the Supplementary material. See locations of the samples in Fig. 2.

several explanations (Huff and Türkmenoglu, 1981). The increase in alkalinity is consistent with submarine weathering of calc-alkaline volcanic rocks to smectite (Perry et al., 1976) whereas hypersalinity in seawater has also been cited as a concentration mechanism for $\mathrm{K}$ in $\mathrm{K}$ bentonites (Huff and Türkmenoglu, 1981). It is noteworthy that tetrahedral substitution of $\mathrm{Al}^{+3}$ for $\mathrm{Si}^{+4}$ in original smectite during diagenesis creates a high layer charge which, in turn, is compensated by K dehydration and fixation (Eslinger et al., 1979). $\mathrm{Al}_{2} \mathrm{O}_{3}$ is increased, and the $\mathrm{Al}_{2} \mathrm{O}_{3} / \mathrm{K}_{2} \mathrm{O}$ ratio decreases with the increase of the metamorphic grade (Huff and Türkmenoglu, 1981). Thus, in K-bentonite SG12-16 the coupled substitutions of $\mathrm{Al}^{+3}+\mathrm{K}^{+1}$ for $\mathrm{Si}^{+4}$ seems to be the most reasonable mechanism for bulk rock $\mathrm{Al}_{2} \mathrm{O}_{3}-\mathrm{K}_{2} \mathrm{O}$ gains and $\mathrm{SiO}_{2}$ loss.

In alumina saturation indices ASI (Shand, 1927) and Th-Co discriminating diagram (Hastie et al., 2007), the El Jagüelito samples plot as peraluminous and belong to high-K calc-alkaline/shoshonitic magma series respectively (Fig. 19 B, C). In the petrographic regard of ASI, a rhyolite lava flow or sill consanguineous with AB-289 display minor garnet phenocrysts indicating the peraluminous character of the parental magma. Although the key peraluminous feature for K-bentonites should be treated with care due to the apparent alumina and alkalis mobilization, they plot coherently along a same evolutionary trend representing a primary geochemical feature of magma, and therefore major-element mobilization seems to be of minor importance.

The REEs and HFSE patterns of K-bentonites are coherent and subparallel concerning each other, and thus they behaved as immobile elements during orogenesis. The chondrite-normalized (Gromet et al., 1984) HFSE diagrams show a relative enrichment in LIL elements and a relative depletion in $\mathrm{Nb}, \mathrm{Sr}, \mathrm{P}$, and Ti (Fig. $19 \mathrm{D}$ ), which are characteristics of subduction-related magmas (Baier et al., 2008).

The chondrite-normalized (Nakamura, 1974) REE diagrams display relative enrichment in light REE with a negative Eu anomaly which is more pronounced in the high-silica rhyolitic ignimbrite SG09-66 (Fig. 19 E). Compared to the other rocks, SG09-66 is enriched in heavy REE whose total content and pattern are almost identical to that pattern of the K-bentonite SG12-16, therefore indicating that they share a common source (Section 7.3).

Finally, although the Cambrian volcanic and pyroclastic rocks of the El Jagüelito Formation underwent regional low-grade metamorphism and deformation, their whole-rock geochemical analyses still closely reflect primary magmatic features. Trace and rare earth elements together 

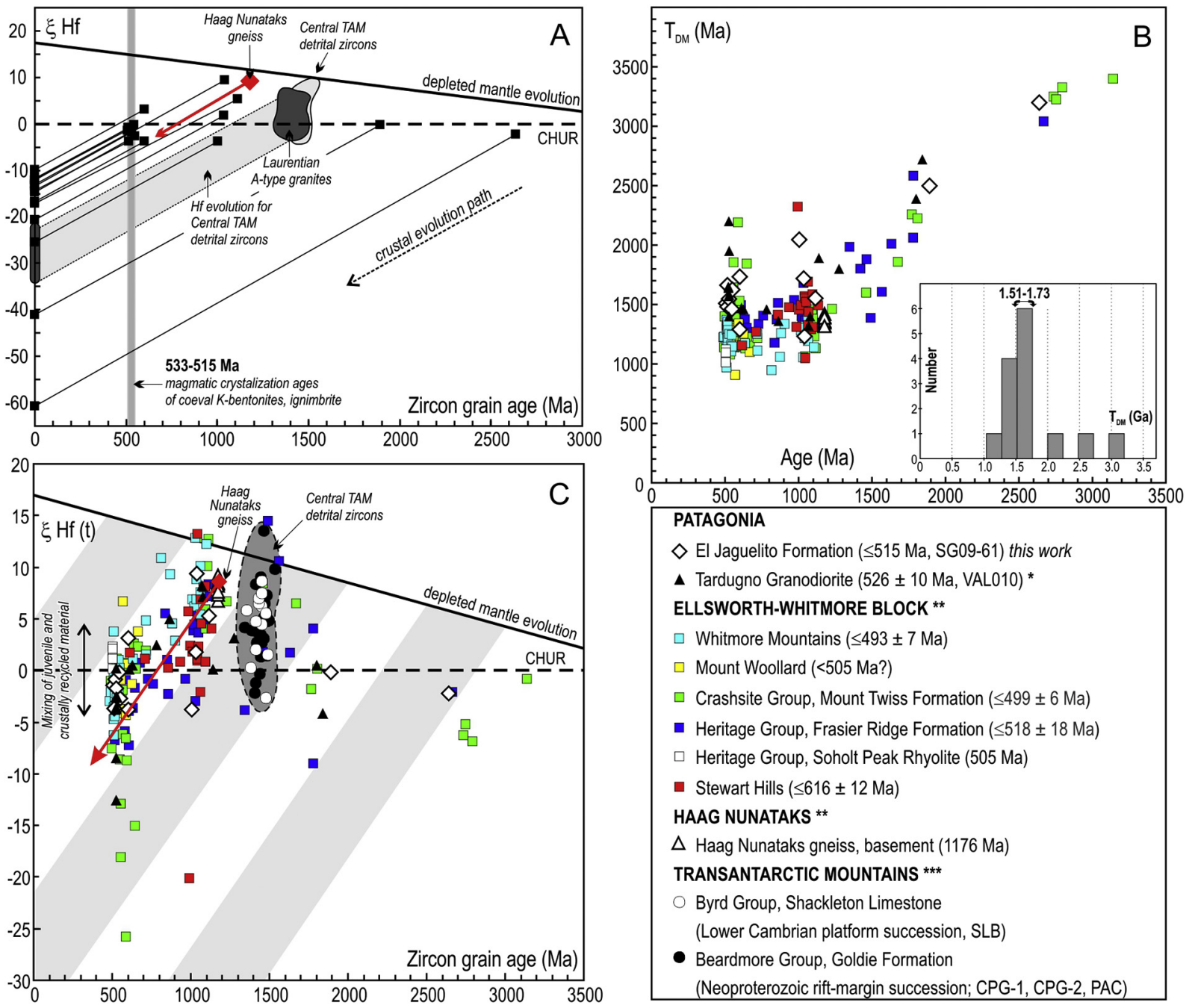

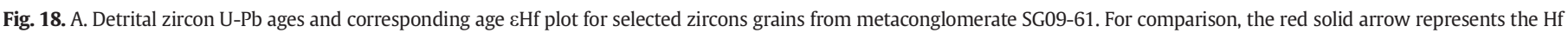

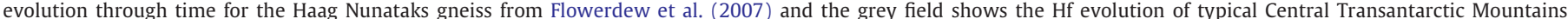

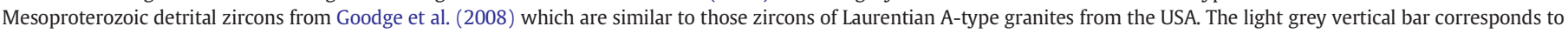

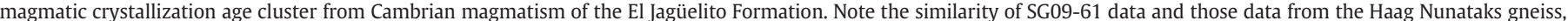

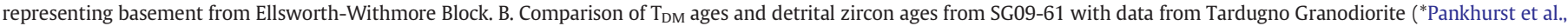

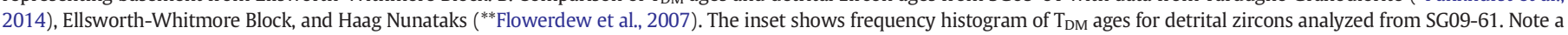

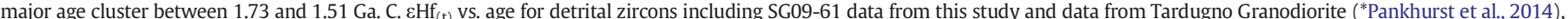

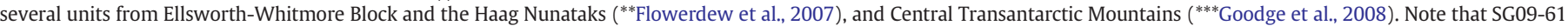

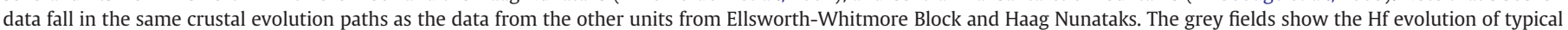

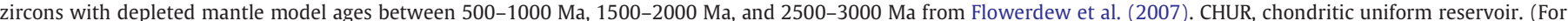
interpretation of the references to color in this figure legend, the reader is referred to the web version of this article.)

are conspicuous for deducing magma sources and are effective petrologic tracers for inferring the tectonic setting as shown below.

\section{Discussion with interpretations}

\subsection{The volcano-sedimentary environment, volcanic facies, and eruptive centers}

The original sedimentary character of protoliths of the low-grade El Jagüelito Formation (Ramos, 1975; Giacosa, 1994) has been improved by successive findings of magmatic protoliths which are interbedded in the sedimentary sequence. Thus, a wider variety of protoliths and therefore, geological processes, were involved in eastern North Patagonian basement before Early Ordovician regional metamorphismdeformation and magmatism took place.

Fig. 20 depicts five tectonostratigraphic sections of El Jagüelito Formation and their lithological comparison with other basement units of the eastern North Patagonian Massif. Within the El Jagüelito Formation exposures, a special correlation can be established between acidic subvolcanic and volcano-pyroclastic complexes and their proximal syneruptive deposits which are more evident to the east of the Sierra Grande area, between León farm and Punta Colorada, whereas air-fall cloud pyroclastic and volcanogenic deposits belonging to distal comagmatic facies are characteristic towards the west (Figs. 2, 20, present geographical coordinates).

The interbedding of lava flows, pyroclastic and volcanogenic rocks within the same sequence and the emplacement of sub-volcanic equivalents, such as domes, dikes and necks suggest that the Leon and Punta Colorada exposures represent two distinct volcanic centers, with similar proximal and distal facies architecture and involving at least two eruptive phases, as shown below in Section 7.2.

In Leon farm, the intimate association of a silicic eruptive cryptodome, explosive and effusive rocks, also interbedded by syneruptive resedimented deposits and reworked primary pyroclastic deposits is typical of the shallow water explosive subvolcanic complex (Gifkins et al., 2005a; McPhie et al., 1993). The abundance of trace fossils 

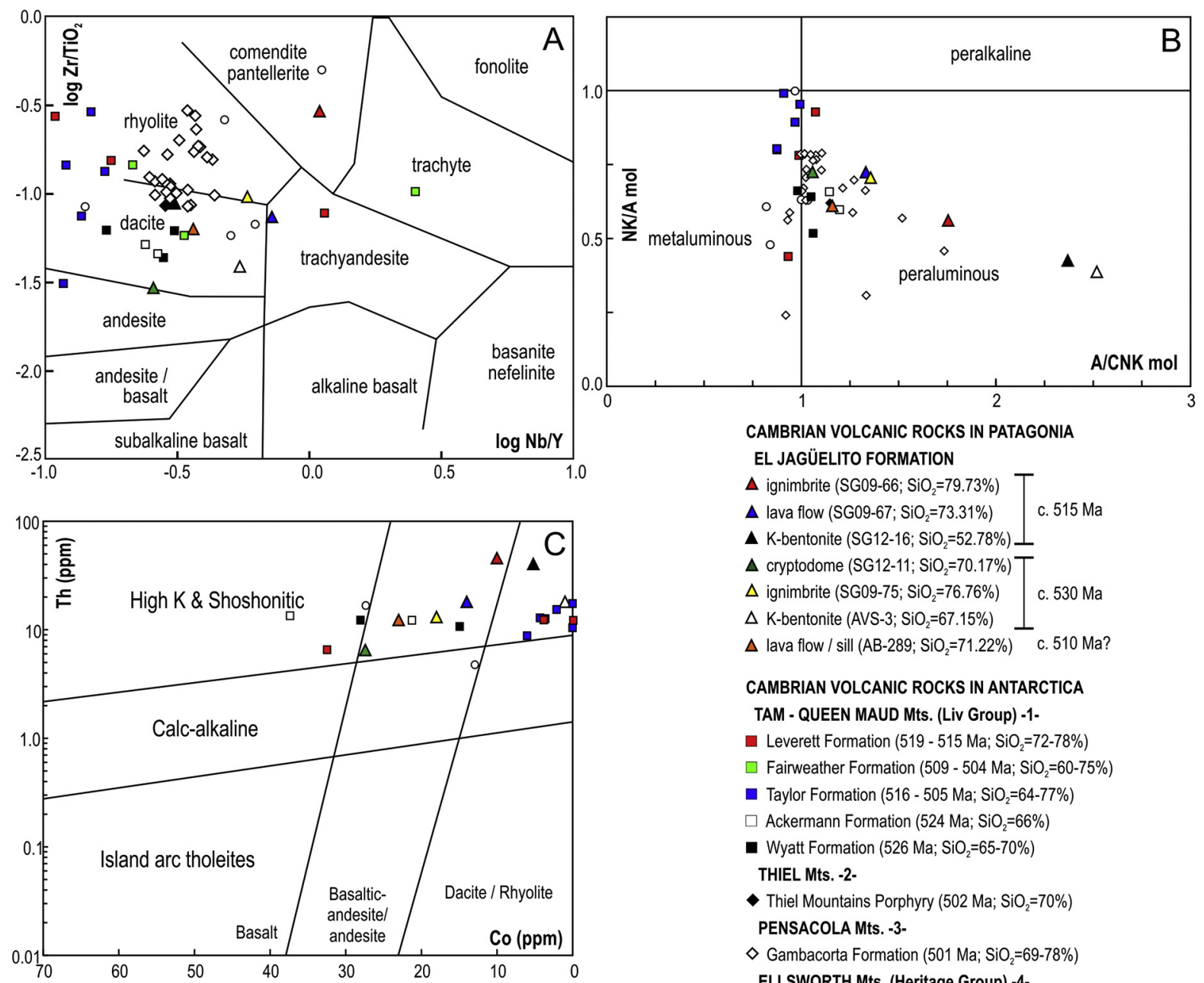

$\Delta$ ignimbrite (SG09-66; $\mathrm{SiO}_{2}=79.73 \%$ )

$\Delta$ lava flow (SG09-67; $\mathrm{SiO}_{2}=73.31 \%$ ) $\quad$ c. $515 \mathrm{Ma}$

$\Delta$ K-bentonite $\left(\mathrm{SG} 12-16 ; \mathrm{SiO}_{2}=52.78 \%\right) \perp$

$\Delta$ cryptodome (SG12-11; $\left.\mathrm{SiO}_{2}=70.17 \%\right)$

$\triangle$ ignimbrite (SG09-75; $\mathrm{SiO}_{2}=76.76 \%$ ) $\quad$ c. $530 \mathrm{Ma}$

$\triangle$ K-bentonite (AVS-3; $\mathrm{SiO}_{2}=67.15 \%$ ) $\perp$

$\Delta$ lava flow / sill (AB-289; $\mathrm{SiO}_{2}=71.22 \%$ ) $\quad$ c. $510 \mathrm{Ma}$ ?

CAMBRIAN VOLCANIC ROCKS IN ANTARCTICA

TAM - QUEEN MAUD Mts. (Liv Group) -1-

— Leverett Formation ( 519 - $515 \mathrm{Ma} ; \mathrm{SiO}_{2}=72-78 \%$ )

$\square$ Fairweather Formation ( $509-504 \mathrm{Ma} ; \mathrm{SiO}_{2}=60-75 \%$ )

- Taylor Formation ( $516-505 \mathrm{Ma} ; \mathrm{SiO}_{2}=64-77 \%$ )

$\square$ Ackermann Formation ( $524 \mathrm{Ma} ; \mathrm{SiO}_{2}=66 \%$ )

- Wyatt Formation (526 Ma; $\mathrm{SiO}_{2}=65-70 \%$ )

THIEL Mts. -2-

- Thiel Mountains Porphyry (502 Ma; $\mathrm{Si}_{2}=70 \%$ )

PENSACOLA Mts. -3-

$\diamond$ Gambacorta Formation ( $501 \mathrm{Ma} ; \mathrm{SiO}_{2}=69-78 \%$ )

ELLSWORTH Mts. (Heritage Group) -4-

O Springer Peak \& Liberty Hills Formations
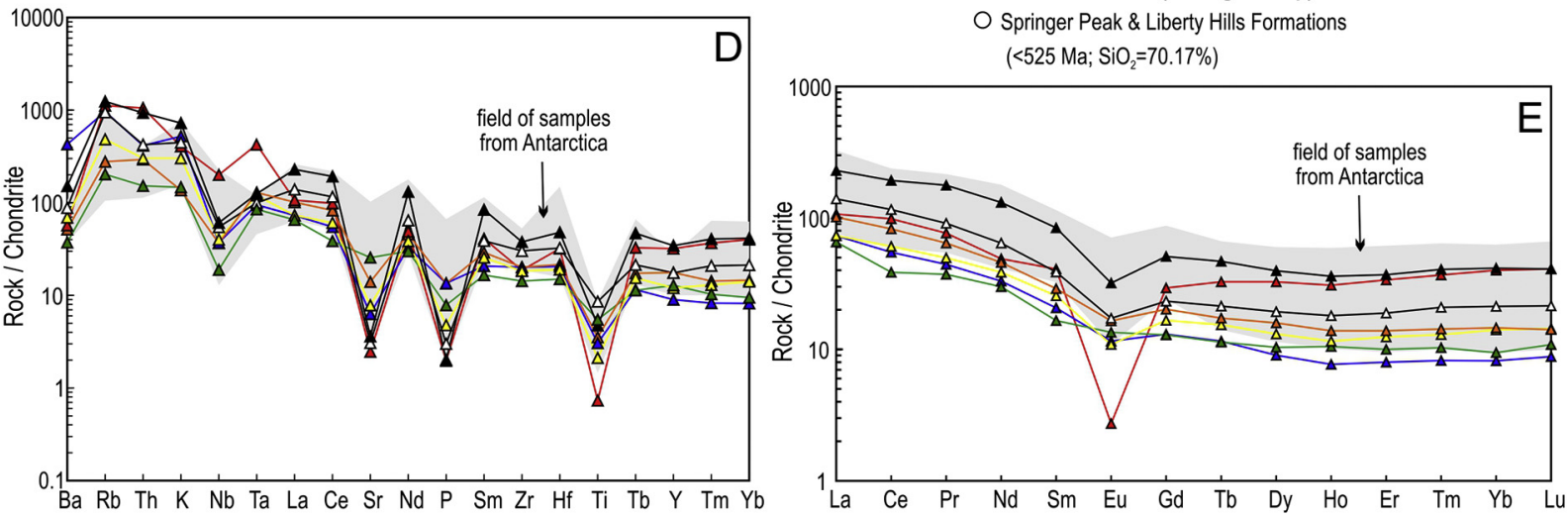

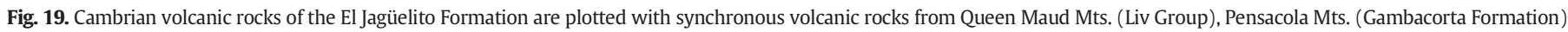

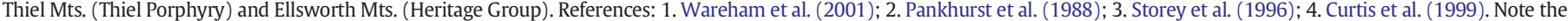

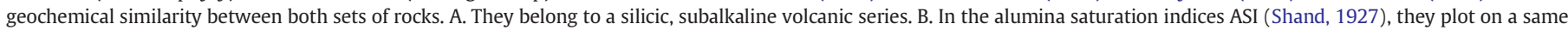

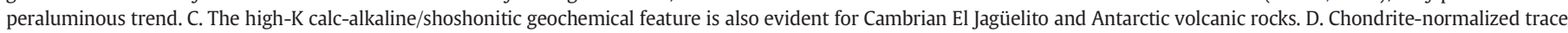
elements plot. E. Chondrite-normalized REE plot. In these spider-diagrams, they show coherent and sub-parallel patterns.

further supports the subaqueous, shallow marine environment in the interbedding pelitic sediments, the quenched volcaniclastic deposits and hyaloclastite and the widespread albite alteration of plagioclase due to seawater-diagenetic alteration/hydrothermal metamorphism. Or even more, by traction current sedimentary structures and bedforms in resedimented syn-eruptive volcaniclastic deposits. Similarly, the hyaloclastite and hyaloclastic breccia are common lithological features in a carapace of domes erupted in the subaqueous environment, owing to intense quench fragmentation and intruding into soft, watersaturated sediments (Stewart and McPhie, 2003; Németh et al., 2008).
Thus, the partly eroded, subaqueous volcanic center in Leon farm is interpreted as the result of shallow marine volcanic eruption coeval with marine sedimentation. The cryptodome preserves both intrusive and extrusive features whereas the ignimbrite, pumice sandstones, and pumice siltstones are related subaqueous facies (Fig. 8). The collapse of a growing shallow subaqueous cryptodome generated the proximal facies of ignimbrite and pumice sandstones.

In the area south of Punta Colorada, subaerial pyroclastic flow and lava flow produced by explosive and effusive eruptions occur in association with co-magmatic sub-volcanic intrusive bodies, as part of a same 


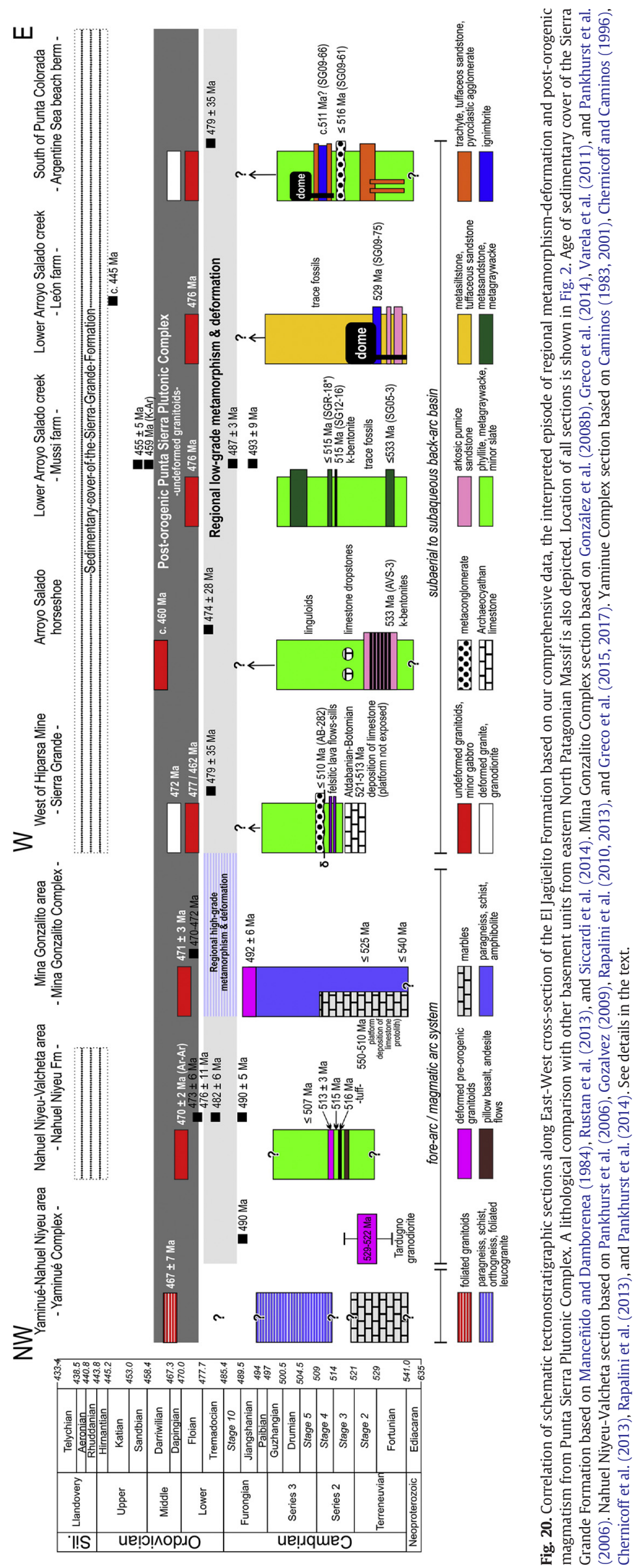


volcano-pyroclastic complex (Fig. 20). They are also linked to volcanogenic conglomerates containing clasts derived from volcanic and pyroclastic rocks and deposited shortly after or synchronously with eruptions. The subaerial environment setting is suggested by the predominance of coherent volcanic or pyroclastic textures (porphyritic and eutaxitic) over quenched fragmentation textures (hyaloclastite) of a subaqueous setting such as those recorded in volcanogenic rocks of the León farm. This dacitic-to-rhyolitic subaerial volcanic center is also well preserved and contemporaneous with deposition of resedimented syn-eruptive volcanic and marine sedimentary protoliths. However, as subaerial volcanic rocks are interbedded with marine pelites and psammites, the eruptive center should have been near or very close to the sea. Pyroclastic flows usually run out distances from a few to tens of kilometers and frequently reach coastlines (Cas and Wright, 1991; Sparks and Huang, 1980; McPhie et al., 1993). They form cliffs around active volcanic islands and seaward of hinterland volcanoes. Thus, the Punta Colorada center could have been flooded by seawater, and therefore volcanic edifices may have occasionally been submerged, in total or in part, changing its eruptive style between subaerial and subaqueous intermittently. The syn-eruptive, rapid erosion of volcanic edifices contributes with cognate volcanic clasts to the proximal facies of volcanogenic conglomerates.

West of the Hiparsa Mine, it is likely the dacitic-to-rhyolitic igneous bodies (i.e., dacite AB-289 among others, Fig. 3) can be either bed of silicic lava flows or intrusive sills concordant to $\mathrm{S}_{0}$ bedding of the sedimentary layers. It is documented that the bodies are not dikes since they do not cut across the host sedimentary layers. However, their primary effusive or intrusive features of the bottom and top contacts as either lava flows or sills remains unclear due to extremely limited exposures (e.g., one or both chilled margins, increase of the size and the percentage of vesicles towards the top, weathering surface on top, among others). Also, the thermal effects immediately adjacent to contacts with underlying and overlying rocks are also unresolved from field data; thus they do not help to interpret the primary igneous feature. Although lava flows or sills are interbedded with marine pelites and greywackes, they do not show petrographic feature indicating an interaction between a hot igneous body and cold sea water or wet sediments, for instance quenching textures, devitrified hyaloclastite, peperites, albitization, among others. Therefore, if they are lava flows, they can be interpreted as erupted in a subaerial environment, as corroborated by coherent massive porphyritic textures, but adjacent to a shoreline (McPhie et al., 1993). Or else, if they correspond to sheet-like bodies of magma paralleling the existing bedding planes, a shallow setting, e.g., sub-volcanic environment, is the most reasonable depth of emplacement.

The linkage of the dacitic-to-rhyolitic bodies and volcanogenic conglomerate AB-282 in the area west of the Hiparsa mine to an eruptive center is not so evident like in the León farm and Punta Colorada complexes, because the bodies do not seem to be geographically related to any specific outcrop which might represent an eruptive volcanic center. For instance, in situ intrusive sub-volcanic domes and proximal volcano-pyroclastic facies (e.g., ignimbrites) that outline those complexes are lacking. Moreover, the provenance area, i.e., volcanic edifice, sub-volcanic bodies, among others, for major volcanic components as proximal facies of volcanogenic conglomerate AB-282 is also concealed.

On account of their high-silica composition, magmas should have been fairly viscous and unable to move far from the vent. Therefore, a local volcanic center close to the Hiparsa mine might have been active contemporaneously with siliciclastic sedimentation as a vent for lava flows or as a feeder for sheet-like intrusions. Thus, a third eruptive center might have been localized somewhere in the surroundings of the Sierra Grande town.

\subsection{The timing of the Cambrian synsedimentary volcanism}

Combining magmatic effusion ages of K-bentonites and one out of two ignimbrites with syn-eruptive depositional ages of conglomerates, make the best fit to constrain the age of the whole volcanosedimentary succession of the El Jagüelito Formation between Early and Middle Cambrian. U-Pb zircon ages obtained in tuffs and ignimbrite suggest bimodality in the eruptive age distribution, and thus two stages of syn-sedimentary volcanism are identified in the evolution of the El Jagüelito Formation as being part of the paleo-Pacific Gondwana margin.

The U-Pb zircon ages of $529.4 \pm 8.4$ and $532.9 \pm 7.3$ Ma from ignimbrite SG09-75 and K-bentonite AVS-3 respectively (Table 1, Figs. 15, 16) constraint the first eruptive stage in El Jagüelito Formation to c. $530 \mathrm{Ma}$, Fortunian. Considering their errors, they are virtually indistinguishable, also from $533 \pm 26$ Ma maximum depositional age of coeval greywacke SG05-3 (Fig. 2, Table 2; data recalculated from Naipauer et al., 2010), and thus, the synchronicity of these pyroclastic and epiclastic deposits is strongly suggested (Fig. 20). Even though ignimbrite comes from proximal pyroclastic flows and the K-bentonite from distal ash fall clouds, both must have erupted from the León volcanic center, and therefore they share similar petrographic and geochemical features (Fig. 19).

Likewise, the effusion ages of ignimbrite SG09-66, K-bentonite SG12-16, and also the syn-eruptive depositional age of the volcanogenic conglomerate SG09-61 are roughly contemporaneous (Tables 1 and 2). Although the scarcity in the degree of c. $511 \mathrm{Ma}$ U-Pb age concordance of magmatic crystallization of the ignimbrite (Fig. 16 C), it is interbedded in the same volcano-sedimentary sequence close to conglomerate SG09-61 (Fig. 10) which has a 515.8 \pm 8.7 Ma maximum depositional age (Fig. 17, Table 2) and a youngest zircon of $501 \pm 11$ Ma (Table 1 of the Supplementary materials). Thus, considering the $515 \mathrm{Ma}$ age and that provenance of clasts and zircons in the conglomerate are predominantly volcanic, both rocks could be contemporary, belonging to proximal facies of the Punta Colorada eruptive center. The date of $511 \mathrm{Ma}$ advises that the effusion age of the ignimbrite can be close to the maximum depositional age of the conglomerate.

In volcanogenic conglomerate SG09-61, provenance from juvenile cognate volcanic and pyroclastic sources is revealed (Section 4.2, Figs. $11 \mathrm{G}, 12 \mathrm{~F}$ ). Considering their $515.8 \pm 8.7 \mathrm{Ma}$ syn-eruptive depositional age, the most likely proximal source area of volcanic and vitroclastic components is the contemporaneous Punta Colorada eruptive center - and equivalents - which is composed of those rocks (Fig. 20). Inputs from the adjacent older Leon center is also likely, as revealed by the younger prominent zircon population around $533 \mathrm{Ma}$ which is interpreted as the age of the source from which zircons were derived and is almost indistinguishable from the magmatic effusion age of the Leon eruptive center and K-bentonite SG12-16 (Figs. 15, 16).

The K-bentonite SG12-16 has a distinct extrusion age of $515.6 \pm$ 2.2 Ma which is indistinguishable from the $515.5 \pm 5.5 \mathrm{Ma}$ maximum depositional age of the host sandstone SGR-018 (Fig. 7, Table 2; data recalculated from Pankhurst et al., 2006), even from the $515.8 \pm$ 8.7 Ma age of the volcanogenic conglomerate SG09-61. Collectively, the set of ages constrains the second eruptive stage to c. $515 \mathrm{Ma}$ (Cambrian, Ages 3-4). In addition, K-bentonite is geochemically similar to ignimbrite SG09-66 thus indicating that they might be consanguineous (Fig. 19). The most likely source of the proximal ignimbrite SG09-66 and distal K-bentonite SG12-16 is the Punta Colorada volcanic center, besides volcanic and pyroclastic detritus in sandstone SGR-018 and conglomerate SG09-61, were probably derived from this volcanic center.

In conglomerate $\mathrm{AB}-282$ which has an essentially magmatic provenance of detrital components and also contains the Archeocyathan limestone blocks, the concordant U-Pb age of $510 \pm 24$ Ma provides a Cambrian, Stage 4 depositional age. The occurrence of an unexposed limestone unit, contemporaneous to the volcanism and the siliciclastic sedimentation, is inferred as a source of the limestone blocks.

Archeocyaths are a benthic group of mostly sessile organisms which inhabited the carbonate shelf and reef environments of the Cambrian seas (Hill, 1972), and thus an Early Cambrian carbonate platform deposition is reasonable to assume (González et al., 2011a). The 
archeocyathan fossils constrain the depositional age of the source limestone to Atdabanian-Botomian (521-513 Ma, Stage 3 to 4; Fig. 20; González et al., 2011a). In this regard, the calcareous sedimentation started after the first stage of synsedimentary volcanism and continued synchronously with eruptions related to c. 515 Ma second stage whereas syn-eruptive siliciclastic sedimentation also continued up to c. 510 Ma or even younger. Thus, deposition of the conglomerate containing volcanic and Archeocyathan limestone clasts should have occurred subsequently, as corroborated by our U-Pb age of $510 \mathrm{Ma}$.

Radiometric dating does not yet constrain the timing of emplacement of the inferred Hiparsa mine volcanic center near Sierra Grande. However, the emplacement of lava flows/sills should have been roughly synchronous with sedimentary deposition of conglomerate AB-282 in which they are interbedded. Thus, an emplacement age of c. $510 \mathrm{Ma}$ or even younger is assumed for the third inferred eruptive center.

In summary, the volcanism is contemporaneous with siliciclastic and calcareous sedimentation within the same sequence and provides insights into the temporal evolution of a major volcano-sedimentary basin in which protoliths of the El Jagüelito Formation were deposited. The U-Pb ages of the ignimbrite and K-bentonite beds joined to provide the U-Pb maximum depositional ages of volcanogenic conglomerates, and the archeocyathan fossils in limestone clasts constrain the age of the volcano-sedimentary pile of the El Jagüelito Formation between Early and Middle Cambrian.

The Cambrian synsedimentary volcanism is diachronic and distributed in, at least, two main stages, i.e., c. 530 and $515 \mathrm{Ma}$, with a third stage not well constrained yet but may also be possible at c. $510 \mathrm{Ma}$.

\subsection{Tectonic setting of the El Jagüelito basin and magma sources}

Collectively, the geological and geochemical features led to the interpretation that the El Jagüelito volcanic rocks might have erupted in an extensional back-arc basin linked to subduction, behind an active continental magmatic arc (Fig. $21 \mathrm{~A}$ ).

As it characterizes the El Jagüelito Formation, the alternation of subaerial and subaqueous volcanic and pyroclastic layers, lenses of syneruptive volcanogenic conglomerates and marine siliciclastic beds within the same sequence, also intruded synchronously by subvolcanic bodies are common features in a chain of volcanic islands belonging to a continental volcanic arc (McPhie et al., 1993; Gifkins et al., 2005a, 2005b; Park, 2018). Both together, the active volcanic islands and the syn-eruptive sedimentation arise in a marine environment.

The volcanic arc axis was situated upon and along a continental area with off-axis subaerial to off-shore subaqueous volcanoes that form islands on the opposing edge of the subducted slab and also associated with an extensional back-arc basin which, in turn, subsequently lead to the development of a rift-related basin (e.g., Park, 2018). Horizontal tension increases in the upper continental plate due to progressive subduction of the negatively buoyant oceanic lithosphere and backarc opening occurs via rollback of the forearc block (Lallemand et al., 2008; Boutelier and Cruden, 2013). This geodynamic scenario seems to be the most reasonable tectonic setting to eruption-to-deposition of the synsedimentary volcanism within the El Jagüelito marine trough as part of a major back-arc basin (Fig. $21 \mathrm{~A}$ ).

From the geochemical point of view, many discrimination diagrams were proposed to infer characteristic magma series associated with specific tectonic settings (e.g., Wilson, 2007 and many references therein). Here, we bring geochemical discrimination diagrams and geological features together to discuss the tectonic setting of synsedimentary volcanism about magmatic arc/back-arc system.

Regardless of the diachronicity of three eruptive centers of the El Jagüelito Formation, its volcanic rocks belong to the same subalkaline, high-K calc-alkaline/shoshonitic magma series and share the same peraluminous trend (Fig. 19 A, B, C). Thus, all dacites-to-rhyolites derived from or have closely similar magmatic sources. Their consanguinity is also revealed by the HFSE and REEs patterns and total element contents which are coherent and sub-parallel between each other (Fig. 19 D, E).

The HFSE patterns with relative depletion in Nb, Sr, P, and Ti (Fig. 19 D) and REE patterns with negative Eu anomaly indicate characteristics of subduction-related magmas, associated to active continental arc magmatism (Pearce et al., 1995; Baier et al., 2008). Sr- and Eudepleted magma as being separated from the plagioclase gave rise to their negative anomalies (Blundy and Wood, 1991). Extreme plagioclase fractionation seems to have occurred in more fractionated highsilica rhyolitic ignimbrites to develop the large negative Eu anomaly.

In the discrimination Th/Y-Ta/Y diagram of Gorton and Schandle (2000) the samples plot transitionally in the fields of active continental margin and within-plate volcanic zones (Fig. 22 A, B). Overlaps between I \& S- orogenic and A-type anorogenic fields and volcanic arc and within-plate fields are also evident in the discrimination diagrams of Whalen et al. (1987) and Pearce et al. (1984) respectively (Fig. 22 C, D). Thus, the behavior of trace and rare earth elements suggests that the tectonic setting of magmas associated to El Jagüelito synsedimentary volcanism could have been associated with an extensional environment within the overall convergent-margin system (e.g., Münker et al., 2004; Dokuz et al., 2006). In this regard, the volcanic rocks of the El Jagüelito Formation are not strongly enriched neither in total REE nor in Sr-P-Zr-Hf contents (Fig. 19 D, E), which are typical geochemical features of within-plate continental rift volcanism (Smedley, 1986; Eby, 1992), and therefore an intraplate tectonic setting to synsedimentary volcanism is unlikely.

The more potassic felsic magmas with inherited subduction-related character of the El Jagüelito Formation erupted in an extensional backarc setting, probably derived from asthenospheric mantle and the continental crust (e.g. Klewin and Shirey, 1992; Keller et al., 2002; Münker et al., 2004; Dokuz et al., 2006; Pearce and Stern, 2006; among others).

Coeval mafic volcanic rocks are absent, and thus the direct involvement of a mantle source in the genesis of the El Jagüelito volcanic rocks seem to be unlikely whereas their felsic rocks are mainly thought to be generated by partial melting of crustal rocks. The peraluminous nature and $\mathrm{Nb}$ negative anomaly of dacitic K-bentonites and highsilica rhyolitic ignimbrites may indicate a crustal involvement in magma processes (Rollinson, 1993), via crustal melting and fractional crystallization (Rudnick, 1992). Nevertheless, there seems to be more than one simple source involved in the generation of felsic magmas, as is characteristic of a back-arc setting in which are involved both the asthenospheric mantle and the continental crust (Keller et al., 2002; Pearce and Stern, 2006).

The HFSE and REE patterns and the high-K calc-alkaline/shoshonitic feature of felsic rocks indicate that magma generation has melts contribution from the supra-subduction zone and continental lithosphere (e.g., Rollinson, 1993; Baier et al., 2008). Coupled with increasingly larger negative Eu anomalies indicate the contribution of progressively more evolved crustal melts, consistent with low-pressure plagioclase fractionation which is typical of processes in crustal magma chambers (Murphy, 2007).

On account of a mantle contribution to felsic rocks, Sr depletion coupled to nearly flat heavy REE pattern between Gd and Lu (Fig. 19 $D, E)$ can be interpreted as disequilibrium during spinel-rich and garnet absent peridotite partial melting in the MORB source asthenospheric mantle (Tang et al., 2012). MORB-like derived melts of asthenospheric mantle that were variably enriched in light REE and LILE by melts from lithospheric mantle and/or continental crust is the most likely source for rocks from extensional settings (Wareham et al., 2001; Curtis et al., 1999; Storey et al., 1996, among others). In addition, the pronounced negative $\mathrm{Nb}$ anomaly in these subduction-related volcanic rocks (Fig. $19 \mathrm{D}$ ) may be explained by the retention of a Nb-bearing phase in the mantle during hydrous melting of the mantle wedge above the subduction zone (Smedley, 1986). 

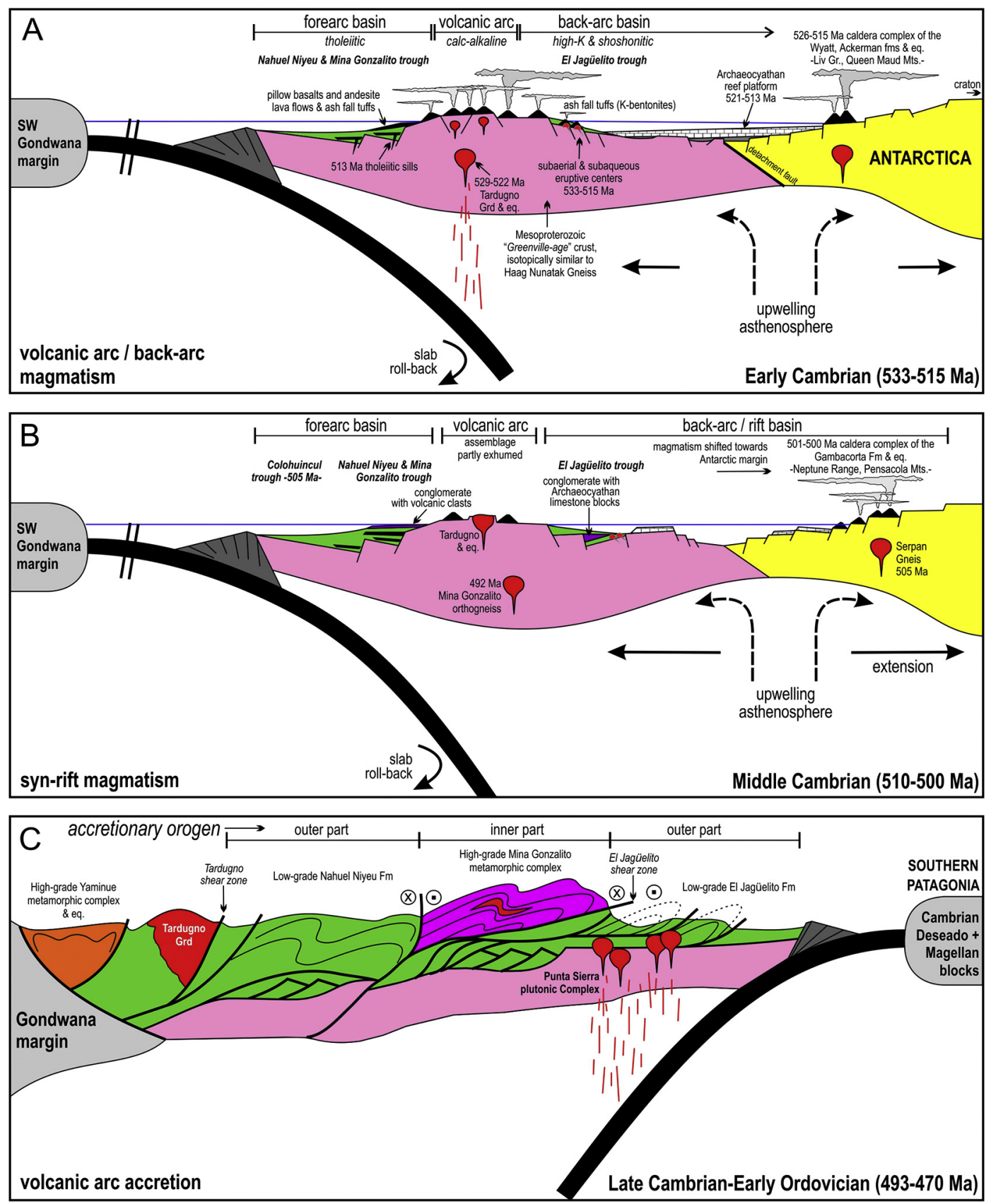

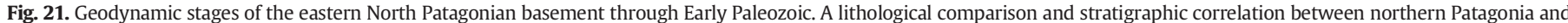

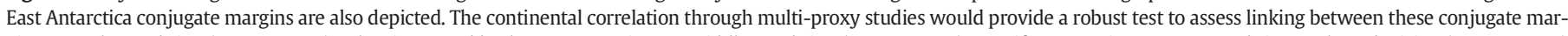

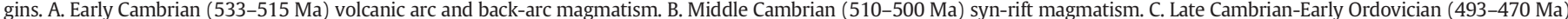

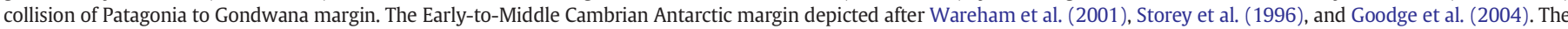

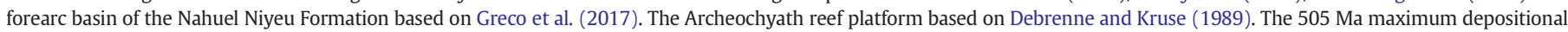
age of the Colohuincul Complex come from Serra Varela et al. (2016). Tectono-stratigraphic references as in Fig. 20.

In the $\mathrm{Rb} / \mathrm{Nb}$ vs. Y/Nb diagram of Eby (1992), the samples plot mostly in the $A_{2}$ field of the post-collisional, post-orogenic and anorogenic magmas derived from K-rich infra-crustal igneous sources, but a minor derivation from $\mathrm{A}_{1}$ rift-related OIB mantle source seems to be also likely (Fig. $22 \mathrm{E}$ ).

The K-bentonites, ignimbrites, and related volcanogenic rocks can be broadly interpreted as products of a mixture between fractionated mafic magmas and partial crustal melts. They would have probably been formed in response to underplating of mafic magmas beneath the arc/back-arc system that produces partial melting of crustal rocks. In convergent and extensional settings, fractional crystallization rather than crustal melting is predominantly responsible for the production of intermediate and felsic magmas, emphasizing the role of mafic cumulates as a residue of crustal differentiation (Keller et al., 2015).

In the eastern North Patagonian Massif, mafic magmas did not erupt on the surface, and thus it can be interpreted that they were emplaced at depth. The near-circular Arroyo Salado and Cerro El Fuerte highs are part of a larger positive gravity anomaly that extends offshore (see Fig. 5 of Gregori et al., 2013) and comprises the Leon and Punta Colorada volcanic centers (e.g., compare with Fig. 2). In the subsurface, these anomalies can be re-interpreted as mainly contributed by underplated mafic magmas beneath North Patagonian Massif. 

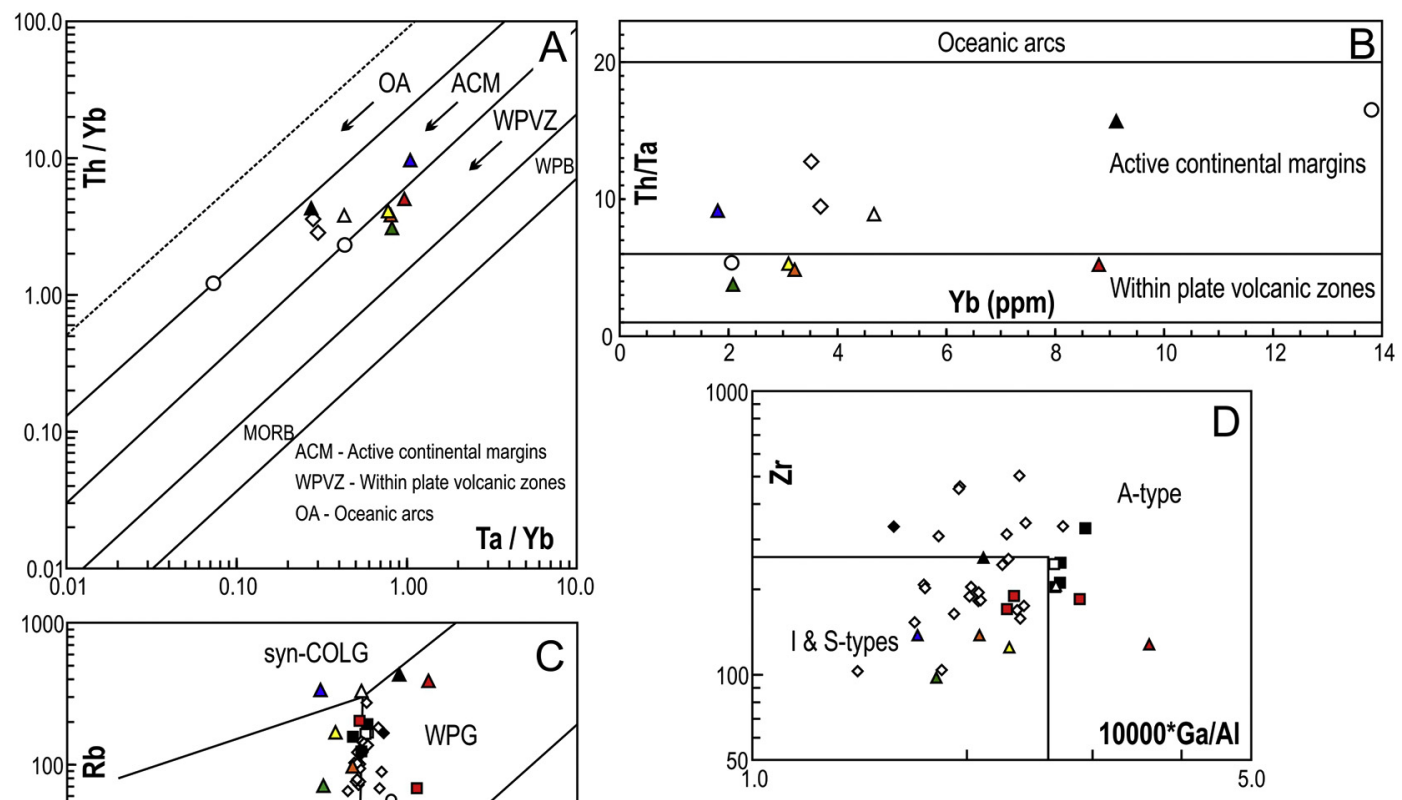
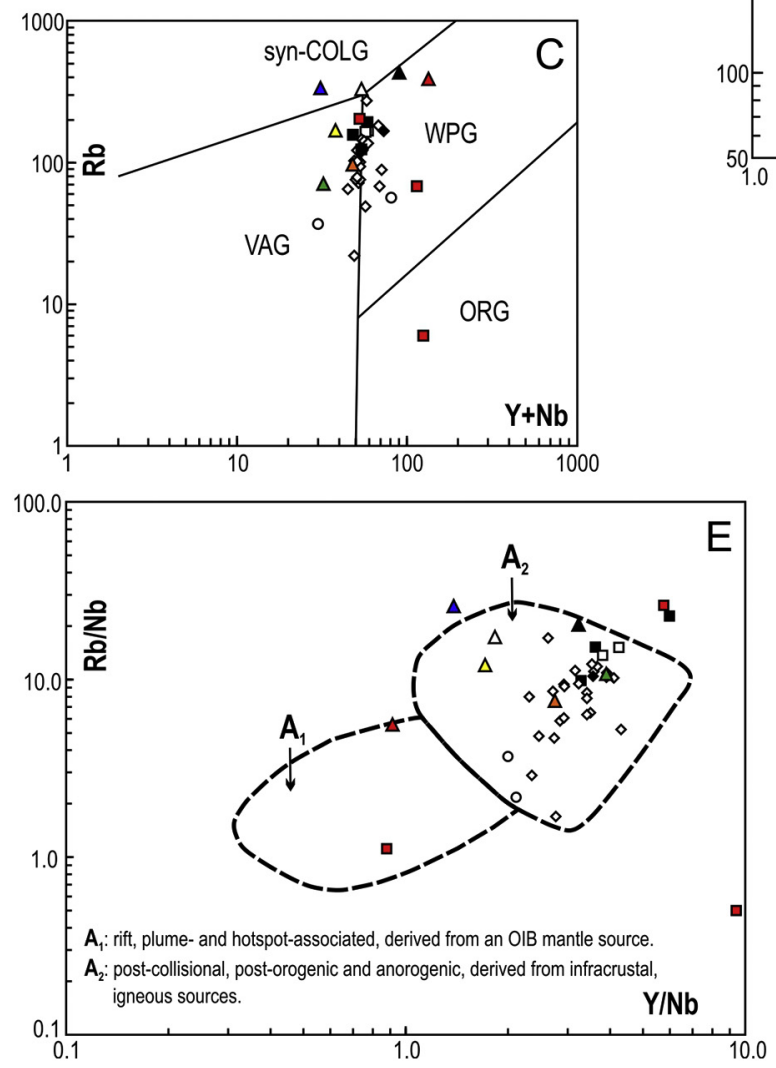

CAMBRIAN VOLCANIC ROCKS IN PATAGONIA

EL JAGÜELITO FORMATION

$\Delta$ ignimbrite $\left(\mathrm{SGO}_{-166} ; \mathrm{SiO}_{2}=79.73 \%\right)$

$\Delta$ lava flow (SG09-67; $\left.\mathrm{SiO}_{2}=73.31 \%\right) \quad$ c. $515 \mathrm{Ma}$

$\Delta$ K-bentonite $\left(\mathrm{SG} 12-16 ; \mathrm{SiO}_{2}=52.78 \%\right) \perp$

$\Delta$ cryptodome ( $\left.\mathrm{SG12-11;} \mathrm{Si}_{2}=70.17 \%\right)$

$\Delta$ ignimbrite $\left(\mathrm{SG09-75} ; \mathrm{SiO}_{2}=76.76 \%\right) \quad$ c. $530 \mathrm{Ma}$

$\triangle$ K-bentonite (AVS-3; $\left.\mathrm{SiO}_{2}=67.15 \%\right) \perp$

$\Delta$ lava flow / sill (AB-289; $\left.\mathrm{SiO}_{2}=71.22 \%\right) \quad$ c. $510 \mathrm{Ma}$ ?

CAMBRIAN VOLCANIC ROCKS IN ANTARCTICA

TAM - QUEEN MAUD Mts. (Liv Group) -1-

- Leverett Formation $\left(519-515 \mathrm{Ma}\right.$; $\mathrm{SiO}_{2}=72-78 \%$ )

$\square$ Fairweather Formation $\left(509-504 \mathrm{Ma} ; \mathrm{SiO}_{2}=60-75 \%\right)$

- Taylor Formation (516 - $\left.505 \mathrm{Ma} ; \mathrm{SiO}_{2}=64-77 \%\right)$

$\square$ Ackermann Formation ( $524 \mathrm{Ma} ; \mathrm{SiO}_{2}=66 \%$ )

- Wyatt Formation ( $526 \mathrm{Ma} ; \mathrm{SiO}_{2}=65-70 \%$ )

THIEL Mts. -2-

- Thiel Mountains Porphyry (502 Ma; $\left.\mathrm{SiO}_{2}=70 \%\right)$

PENSACOLA Mts. -3-

$\diamond$ Gambacorta Formation ( $501 \mathrm{Ma} ; \mathrm{SiO}_{2}=69-78 \%$ )

ELLSWORTH Mts. (Heritage Group) -4-

O Springer Peak \& Liberty Hills Formations ( $<525 \mathrm{Ma} ; \mathrm{SiO}_{2}=70.17 \%$ )

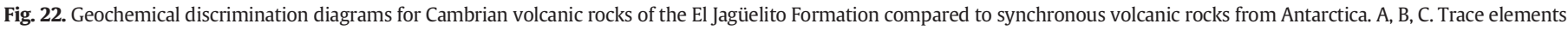

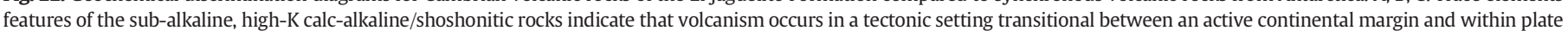

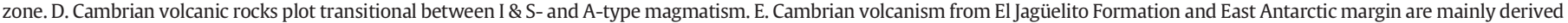
from $A_{1}$ infracrustal igneous sources and minor $A_{2}$ OIB-like mantle source. References for Antarctic rocks as in Fig. 19.

\subsection{Cambrian geodynamic scenario for the North Patagonian Massif}

Fig. 20 depicts tectonostratigraphic sections across the three distinct basement areas of the eastern North Patagonian Massif (see also Fig. 2 for the location of the areas). From Northwest to Southeast, the basement rocks in Yaminué-Nahuel Niyeu, Mina Gonzalito-Sierra Pailemán and Sierra Grande-Arroyo Salado areas shared a common geological evolution during the Early Paleozoic. Regional correlations between them point towards the volcano-sedimentary sequence of the El Jagüelito Formation that has striking lithological and geochronological similarities to Cambrian sequences of the Nahuel Niyeu Formation and Mina Gonzalito Complex. Considering a magmatic arc-back arc system as the most likely Cambrian geodynamic setting to the El Jagüelito Formation, the relative position of all these units across the arc is the forearc Nahuel Niyeu Formation (Greco et al., 2017) and also possibly the Mina Gonzalito Complex, and the magmatic arc represented by Tardugno Granodiorite and equivalents (Pankhurst et al., 2014).

A special correlation can be established among coeval volcanic protoliths on both sides of the magmatic arc, i.e., between the forearc Nahuel Niyeu Formation and the back-arc El Jagüelito Formation (Fig. $21 \mathrm{~A}$ ). Thus, volcanic eruptions coming from the arc deposited multiple volcanic ash layers, later transformed to illite-rich K bentonites, ignimbrites and lava flows in the adjacent forearc and back-arc basins, but with dissimilar geochemical features due to its different tectonic settings. There seems to be a spatial zonation of the magmatic suites across the arc which is successively more potassium-rich towards the back arc (e.g., see Morrison, 1980; Hastie et al., 2007). 
Within the Nahuel Niyeu exposures, synsedimentary volcanism is present as $513 \mathrm{Ma}$ tholeiitic composite sills and dikes, three horizons of tuffs (K-bentonites?) and a number of beds of subaqueous lava flows of tholeiitic pillow basalts and andesites among others, but without age constraint yet (Greco et al., 2015, 2017). They are all close to the oceanic trench and thus mainly of tholeiitic signature (Greco et al., 2015) whereas high-K calc-alkaline/shoshonitic volcano-pyroclastic rocks of the El Jagüelito Formation are more distant from an oceanic trench in a back-arc position (Figs. 20, $21 \mathrm{~A}$ ).

The three horizons of tuffs interbedded in the sedimentary protoliths of the Nahuel Niyeu Formation are key correlative horizons of the $515 \mathrm{Ma}$ K-bentonites and ignimbrites of the El Jagüelito Formation. Maximum depositional ages are between 516 and 515 Ma for siliciclastic protoliths of the Nahuel Niyeu Formation (Pankhurst et al., 2006; Rapalini et al., 2013; Greco et al., 2017) in which tuffs are interbedded and support tuffs correlation as marker horizons between the forearc and the back-arc basins. Thus, the c. 515 Ma second eruptive stage of the back-arc basin is also recorded in the forearc region. However, given that most of the forearc volcanic beds are not yet constrained by radiometric dating, e.g., pillow basalts and andesites, we can envisage magmatic crystallization ages older than 515 Ma for synsedimentary volcanism of the Nahuel Niyeu Formation, and then Early Cambrian ages associated with the first eruptive stage cannot be completely ruled out in the forearc basin.

The calc-alkaline, subduction-related magmatism emplaced in the axis of the magmatic arc is represented by Early Cambrian granitoids of the Tardugno Granodiorite (SHRIMP U-Pb zircon ages of 529, 526 and 522 Ma, Rapalini et al., 2013; Pankhurst et al., 2014) which is tectonically juxtaposed against Nahuel Niyeu Formation (von Gosen, 2003). The U-Pb zircon ages allow including Tardugno Granodiorite as the plutonic equivalent of the volcanic rocks related to the first eruptive stage.

The country rocks of the Tardugno Granodiorite are considered to be of the volcano-sedimentary sequence of the Nahuel Niyeu Formation (Caminos, 2001) or may even be older and of Precambrian age (Chernicoff et al., 2013). Together with petrological and geochemical information, Pankhurst et al. (2014) considered a previously suggested idea of Dalla Salda et al. (1992) that these Cambrian granitoids represent a southern continuation of the Pampean orogenic belt of the Sierras Pampeanas as part of the autochthonous margin of Gondwana (Fig. 1 A). However, our alternative interpretation does support the hypothesis of Ramos and Naipauer (2014) that Patagonia is the conjugate margin of Pensacola Mts., and thus the magmatic arc-back arc system is parautochthonous being originated in Antarctica and accreted to the southwest Gondwana margin. The arguments supporting this idea are reviewed below in Sections 7.5 and 7.6.

Most of the El Jagüelito and Nahuel Niyeu sediments are syneruptive and were supplied from the active magmatic arc which retreats in step with the roll-back of the slab plate. Multi-proxy sediment provenance data from greywackes, sandstones and pelites of the El Jagüelito (Huber-Grünberg, 1990; Giacosa, 1997; Dalla Salda et al., 2003a) and Nahuel Niyeu formations (Cagnoni et al., 1993; Greco et al., 2017), such as petrographic and whole-rock geochemical analyses, heavy minerals and DRX patterns, indicate the main inputs of calc-alkaline, intermediate to acidic magmatic sources in detrital components which could have been supplied from volcanic and pyroclastic rocks exposed along a coeval active volcanic arc. Early to Middle Cambrian age magmatism in the source area of greywackes and sandstones is corroborated by their maximum depositional ages. Two clusters of younger zircon ages of $533 \pm 26$ (sample SG05-3, Naipauer et al., 2010) and $515 \pm 5 \mathrm{Ma}$ (sample SGR-018, Pankhurst et al., 2006) are equal to the first and second eruptive stages respectively of the synsedimentary magmatism of the El Jagüelito Formation (Section 7.2 and Tables 1 and 2) whereas in the Nahuel Niyeu Formation, the 515 and 516 Ma maximum depositional ages (Pankhurst et al., 2006; Rapalini et al., 2013; Greco et al., 2017) agree with a second eruptive stage.
Further evidence of Cambrian sedimentation and magmatism is in the Mina Gonzalito Complex which was lithologically considered as the higher grade metamorphic equivalent of the El Jagüelito Formation (Caminos and Llambías, 1984; Giacosa, 1987, 1994; Fig. 20). Concerning the volcanic protoliths, but without age constraint yet, amphibolites and felsic meta-volcanic rocks were considered as the metamorphic equivalents of tholeiitic basalts and andesites-to-rhyolites respectively (Dalla Salda et al., 2005; González et al., 2008b).

The deposition of siliciclastic protoliths in the Early Cambrian is constrained by $\mathrm{U}-\mathrm{Pb}$ detrital zircon analyses of two paragneisses that yielded youngest age peaks at c. $540 \mathrm{Ma}$ (Pankhurst et al., 2006) and c. $525 \mathrm{Ma}$ (Greco et al., 2014). Additionally, an orthogneiss with SHRIMP U-Pb studies has disclosed a Furongian magmatic crystallization age of $492 \pm 6 \mathrm{Ma}$ (Varela et al., 2011).

The intimate association of siliciclastic sedimentary and mafic to felsic volcanic protoliths, also interbedded with limestones (Dalla Salda et al., 2003b) within the same sequence of the Mina Gonzalito Complex was considered as a supracrustal assemblage deposited along active continental magmatic arc dominated by a marine environment (Dalla Salda et al., 2005), in close analogy to the Nahuel Niyeu-El Jagüelito pair.

In summary, a magmatic arc-back arc system is the most likely Early-to-Middle Cambrian geodynamic setting for all basement rocks of the eastern North Patagonian Massif. Although there may be a complete gradation between the Nahuel Niyeu-Tardugno, Mina Gonzalito, and El Jagüelito magmatic suites, more K-rich magmas of the El Jagüelito Formation could be generated by successively steepening the subduction zone (e.g., Morrison, 1980). A slab roll-back should be an appropriate tectonic mechanism that probably produced extension with block tilting and high-K calc-alkaline/shoshonitic magmas above the subduction zone. The extension may occur on the oceanward side of the volcanic front, and the magmas may be generated as a consequence of extensional tectonics (Wilson, 2007). The magmas associated with landward off-axis subaerial volcanoes and oceanward off-shore subaqueous chain of the volcanic island from El Jagüelito Formation are more alkali than the subduction-related tholeiitic and calc-alkaline magmas of the Nahuel Niyeu Formation and Tardugno Granodiorite respectively (Figs. 20, 21 A). Then, there is a spatial zonation of the magmatic suites across the arc which is successively more potassium-rich towards the back arc.

\subsection{Patagonia-Antarctica Early Paleozoic conjugate margins}

We attempt here a comprehensive lithologic, tectono-stratigraphic, geochemical and Hf isotopes, and U-Pb geochronologic comparison between basement rocks of the eastern North Patagonian Massif and several Early-to-Middle Cambrian units from the western margin of East Antarctica, i.e. the Gambacorta and Patuxent formations of the Pensacola Mts. (Storey et al., 1996), the Liv Group of the Queen Maud Mts. in Transantarctic Mountains (Wareham et al., 2001), the Heritage Group of the Ellsworth-Whitmore block (Curtis et al., 1999), and the Thiel Mountain porphyry (Pankhurst et al., 1988), to evaluate the tectonic hypothesis of Ramos and Naipauer (2014) in which the eastern North Patagonian Massif was the conjugate margin of the Pensacola Mountains during the Early Paleozoic. Overall similarities of the Archeocyath fauna is fairly well analyzed since these fossils are strong provenance markers and good for biostratigraphic correlation across Gondwana continent.

Collectively, our results sustain the Antarctic connection of the El Jagüelito Formation and allow proposing a parautochthonous origin of the eastern North Patagonian Massif to Gondwana, as an outboard assemblage which was the conjugate margin of the inboard PensacolaQueen Maud-Ellsworth Mountains in East Antarctica during Cambrian times (Fig. 21).

The similarities of geological evolution along Patagonia-Antarctica conjugate margins are Cambrian synsedimentary volcanic and 
pyroclastic rocks, volcanogenic conglomerates, Archeochyathan limestones and conglomerates with volcanic and fossiliferous limestone clasts derived from coeval units, which are all interbedded in siliciclastic rocks as part of the same sequence. The magmatic crystallization ages of the Antarctic counterpart can also be distributed among the three eruptive stages, as is described in this contribution to the El Jagüelito Formation, and even volcanic beds are petrographically and geochemically analogous between each other.

\subsubsection{Lithologic and geochronologic comparison}

Concerning the first and second eruptive stages, the forearc Nahuel Niyeu and back-arc El Jagüelito volcanic beds are synchronous to volcanic rocks of the Liv Group from the rift-related Antarctic margin (Fig. 21 A). In this regard, the Nahuel Niyeu-El Jagüelito pair is parallel to some beds of dacitic tuffs, ignimbrites and dacites interbedded in argillites, shales, sandstones, and conglomerates with volcanic clasts of the Wyatt and Ackerman formations of the Liv Group. U-Pb zircon ages of $526 \pm 2$ Ma on ash-flow tuff and $524 \pm 2$ Ma on dacitic lava flow of the Wyatt and Ackerman formations respectively (Encarnación and Grunow, 1996) point to the timing of their eruption from a subaerial caldera complex implanted on rift shoulders to Early Cambrian (Encarnación et al., 1999; Wareham et al., 2001).

Although Wyatt and Ackerman's formations are somewhat younger than the 533-529 Ma range of effusion ages in the back-arc, we consider them as roughly coeval and include them as an Antarctic counterpart of the first eruptive stage since they share the same geochemical features as the El Jagüelito volcanic rocks, suggesting consanguinity in the same extensional tectonic setting (Figs. 19, 22, see also below).

Belonging to the second eruptive stage, the younger 519-516 Ma bimodal suite from the Taylor and Leverett formations of the same Liv Group may correlate with the c. 516 Ma tholeiitic basalts to andesites and 513 Ma composite sills and dikes of the Nahuel Niyeu Formation (Greco et al., 2015). Additionally, tuff horizons of c.516 Ma (Greco et al., 2017) and 515 Ma dacitic-to-rhyolitic K-bentonite and ignimbrite of the Nahuel Niyeu and El Jagüelito formations respectively are key correlative horizons of the $516 \pm 6$ Ma meta-rhyolite and $515 \pm 4$ Ma felsic rocks of the Taylor and Leverett formations (Van Schmus et al., 1997), and even of the $512 \pm 14$ Ma hyaloclastite (Rees et al., 1997) of the Heritage Group at Heritage Range, Ellsworth Mts. In this latter group, the $\sim 3000 \mathrm{~m}$ thick sequence of basal terrestrial lahars, ash-flow tuffs, and 512 Ma hyaloclastite predominate over the top successions composed predominantly of interbedding basalts, less basaltic andesites, and minor silicic rocks and polymictic conglomerates (Conglomerate Ridge Formation with granite clasts dated at $532 \pm 5$ and $525 \pm 2 \mathrm{Ma}$, Rees et al., 1995). Within the Early Paleozoic Heritage Group, the association of rapid lateral facies changes, the presence of dominantly felsic bimodal volcanism, and syn-extrusive extensional faults associated with volcanic centers support an extensional tectonic setting (Vennum and Storey, 1987; Vennum et al., 1992; Webers et al., 1992; Curtis et al., 1999; Curtis and Lomas, 1999; Curtis, 2001; Webers and Splettstoesser, 2007, among others).

In the inboard side of the back-arc basin, at the Antarctic conjugate margin, the third eruptive stage is better constrained than Patagonia by radiometric dating between 510 and $500 \mathrm{Ma}$. The continental arc crust under extension due to slab retreat resulted in a pulse of rifting that triggered changes in magma source regions (Fig. $21 \mathrm{~B}$, see also Section 7.6). The propagation events have transferred volcanic centers and sedimentary troughs from arc-proximal to more arc-distal positions. By c. 510 Ma the arc/back-arc magmatism ceased in Patagonia, and the locus of volcanic activity shifted to the Antarctic margin (Boger and Miller, 2004; Paulsen et al., 2007, 2008). For instance, the caldera complex of Taylor and Fairweather formations (Queen Maud Mts.) still register rift-related bimodal volcanic activity at c. 505-504 Ma (Encarnación et al., 1999) with the eruption of air-fall tuffs, tuff breccias and welded ignimbrites (Wareham et al., 2001), while coeval syn-rift sedimentation of the Fairweather Formation record maximum depositional ages of $509+8-9$ and $504 \pm 3$ Ma (Paulsen et al., 2015). Additionally, silicic ash-flow tuffs, ignimbrites and agglomerates and lava flows of the Gambacorta Formation (Schmidt et al., 1964) dated at c. 501-500 Ma (Millar and Storey, 1995; Van Schmus et al., 1997) that erupted from a rift-related caldera complex (Curtis et al., 2004). Or else yet, the Patuxent Formation of the Neptune and Patuxent ranges is the lateral equivalent of Gambacorta Formation (Curtis and Storey, 2003), with a correlation based on the U-Pb dating of c. $500 \mathrm{Ma}$ redeposited felsite blocks (Millar and Storey, 1995) and detrital zircons (Rowell et al., 2001; Goodge et al., 2004) and the presence of an extensive rift-related suite of coeval bimodal volcanic rocks (Rowell et al., 2001; Curtis and Storey, 2003).

Further West at the outboard Patagonian assemblage, the upper part of the tectonostratigraphic sequence of the Nahuel Niyeu and El Jagüelito formation has a maximum depositional age of c. $507 \mathrm{Ma}$ (Rapalini et al., 2010) and c. $510 \mathrm{Ma}$ (this contribution) in close analogy to the Taylor, Fairweather, Gambacorta, and Patuxent formations of the Antarctic conjugate margin (Fig. $21 \mathrm{~B}$ ).

In summary, considering Patagonia and Antartica as Early-to-Middle Cambrian conjugate margins, the outboard assemblage represented by forearc-to-backarc volcano-sedimentary sequences of the Nahuel Niyeu and El Jagüelito formations has striking lithological and geochronological similarities to the inboard assemblage of the Ellsworth-Whitmore, Pensacola, and Queen Maud Mountains (Fig. 23). However, the volcanopyroclastic rocks belong to different magmatic suites as it is shown below, due to its different geotectonic positions across conjugate margins.

\subsubsection{Geochemical correlation}

In Antarctica, the Early-to-Middle Cambrian synsedimentary volcanism suggests periodic extension within the overall convergentmargin system. A rift-related setting is recognized to volcanic rocks of the Liv Group in Queen Maud Mts. and the Heritage Group of the Ellsworth Mts. (Curtis et al., 1999; Wareham et al., 2001) whereas the Gambacorta Formation of the Pensacola Mts. was considered as part of the inboard assemblage of a magmatic arc (Storey et al., 1996). Thus, the most likely tectonic setting was an extensional rift environment within or behind an active volcanic arc (Wareham et al., 2001). All the above units fit in well within geodynamic scenario proposed here for Patagonia-Antarctica conjugate margins in which Antarctic rocks have occupied the inboard side of the extensional environment (Fig. 21).

Following the alumina saturation indices ASI (Shand, 1927) and a Th-Co discrimination diagram for arc volcanism (Hastie et al., 2007), the c. 530 to c. 515 Ma volcanic rocks of the El Jagüelito Formation are plotted for geochemical comparison with synchronous 526 to $501 \mathrm{Ma}$, mesosilicic to acidic volcanic and pyroclastic rocks from Antarctica (Fig. 19). The dacites-to-rhyolites of the El Jagüelito Formation plot on the peraluminous trend defined by silicic volcanic rocks from Antarctica and overlap within the subalkaline series in $\mathrm{Nb} / \mathrm{Y}-\mathrm{Zr} / \mathrm{TiO}{ }_{2}$ diagram, all belonging to the same co-magmatic, high-K calc-alkaline/ shoshonitic magma series (Fig. 19 A-C).

The consanguinity among coeval volcanic rocks along conjugate margins is also revealed by strong similarities in HFSE and REEs patterns and total element contents which are coherent and sub-parallel between each other. However, the Antarctic rocks are slightly enriched in total REE contents and have higher Nb-Sr-P-Zr-Hf contents (Fig. 19 D, E) which are typical geochemical features of rift-related magmas (Eby, 1992).

Bimodality in the magmatic suite distribution is also a typical feature for rift-related magmatic rocks and are lacking in the Wyatt and Ackermann formations (Wareham et al., 2001), in close analogy to El Jagüelito Formation (Fig. 21 A). Therefore, their silicic magmas were erupted on the rift flanks and shoulders, in off-rift axis position, and are characterized by more potassic magmas with inherited subduction-related character derived from the lithospheric mantle (Gibson et al., 1993; Curtis et al., 1999; Wareham et al., 2001). The prominent mafic compositions of the Taylor, Fairweather, and Leverett 


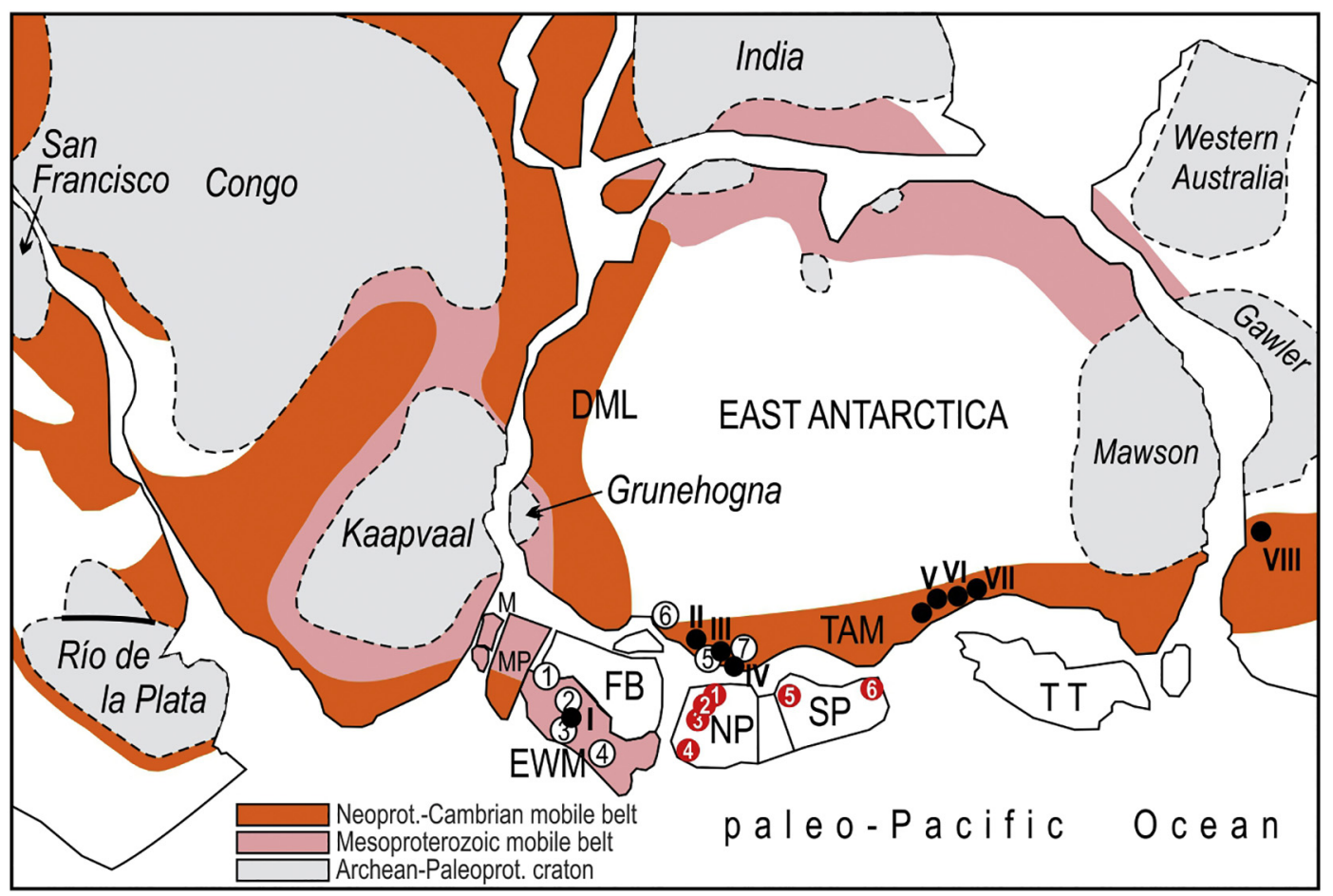

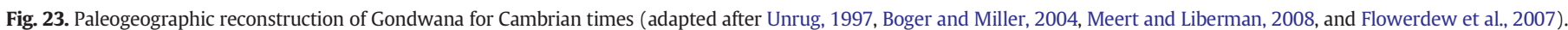

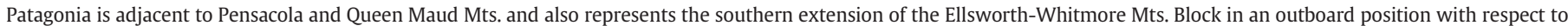

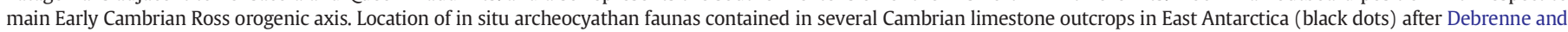

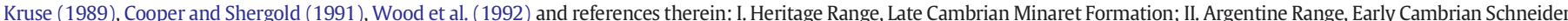

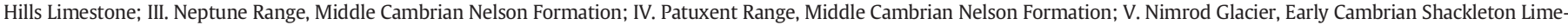

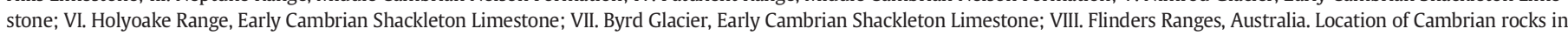

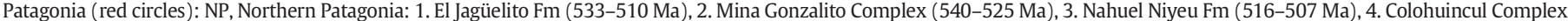

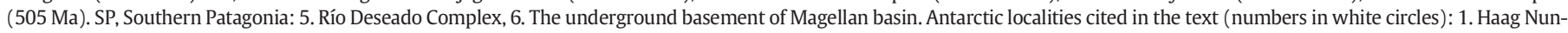

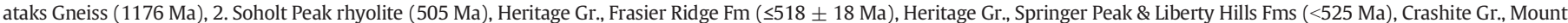

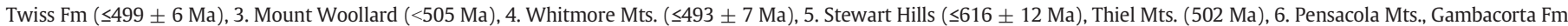

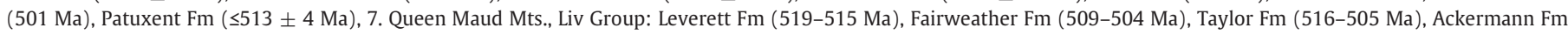

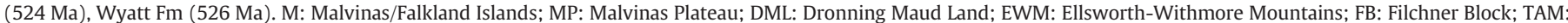

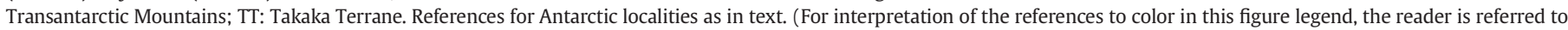
the web version of this article.)

formations of the same Liv Group (Wareham et al., 2001) were emplaced in a more central position near the rift axis, between the back-arc El Jagüelito trough and half-grabens of the Wyatt and Ackermann formations (Fig. 21 B). Peraluminous, high-K calc-alkaline/ shoshonitic magmas of the coeval El Jagüelito Formation and Liv Group, are more distant from the oceanic trench and could be generated by slab roll-back of the subducting plate.

Regarding magma sources along conjugate margins, the rhyolites of the Wyatt and Ackermann formations are interpreted to be partial melts of continental crust that may be as old as $1.5 \mathrm{Ga}$ (Wareham et al., 2001) similarly to El Jagüelito volcanic rocks. Nevertheless, the most depleted basalts of the Taylor, Fairweather, and Leverett formations are interpreted as melts of asthenospheric mantle that were variably enriched in light REE and LILE by melts from the lithospheric mantle and/or continental crust, whereas the rhyolites are interpreted as mixtures of a fractionated mafic magma and partial crustal melts (Wareham et al., 2001).

In summary, the felsic rocks of the El Jagüelito Formation and the Liv Group, i.e., along conjugate margins, were probably generated in response to the underplated mafic magmatism that produced partial melting of crustal rocks in an extensional environment within the overall convergent-margin system.

\subsubsection{Hf isotopes as a petrologic tracer of magma sources}

Fig. 18 depicts Hf isotope composition of the dated zircons from conglomerate SG09-61 that further provide information of magmatic sources and allow proposing a Grenvillian-age Late Mesoproterozoic input to magma generation in the parental source area. The solid red arrow represents the $\mathrm{Hf}$ evolution through time (after Flowerdew et al., 2007) for the c. 1176 Ma Haag Nunataks gneiss (Millar and Pankhurst, 1987) from northeast of the Ellsworth Mts.

$\varepsilon \mathrm{Hf}$ positive values that correspond to depleted juvenile mantle model ages of around $1.5 \mathrm{Ga}$ from the late Mesoproterozoic zircon population predominantly plot scattered around the evolution trend of the Haag Nunataks gneiss and match those in volcano-sedimentary rocks of similar age from the Ellsworth-Withmore block (Fig. 18 A-C), may suggesting sources that recycle sedimentary and volcanic derivatives from the Ellsworth-Withmore block are more likely. There is one exception; a grain with a negative $\varepsilon \mathrm{Hf}$ value and model age $>1.5$ Ga plot within the evolution trend of Central Transantarctic Mountains detrital zircons which were derived from Laurentian A-type granites (Goodge et al., 2008), and thus minor provenance from central TAM basement is also likely.

The majority of the Cambrian detrital zircons have $\mathrm{EHf}$ values that fall along the evolution trend of the Haag Nunatak gneisses, indicating that magma from which they crystallized was derived from partial melting of Mesoproterozoic "Grenvillian age" crust similar to that gneiss (Fig. 18 A). Considering age and Hf data as a whole, a source region that satisfies the juvenile nature of the late Mesoproterozoic grains and can provide Cambrian grains generated by remelting late Mesoproterozoic juvenile crust is the Ellsworth-Whitmore Mts. block (Fig. 23). In addition, $\mathrm{T}_{\mathrm{DM}}$ range of ages match those in the Haag Nunataks gneiss and sedimentary and volcanic rocks of similar age in the EllsworthWhitmore Mts. block, and the Hf isotope signature from Tardugno 
Granodiorite suggests derivation by mixing of juvenile mantle-derived and crustally recycled components of similar composition to that exposed in the Haag Nunataks gneisses (Fig. 18 B).

The Hf isotope composition of inherited grains and igneous zircons formed during crystallization of the Tardugno Granodiorite (Pankhurst et al., 2014) match the Hf signature of the detrital igneous zircons from volcanogenic conglomerate SG09-61 (Fig. 18 A, C), showing that a common magma was derived from pre-existing crustal material in the source region of Patagonia. $\varepsilon \mathrm{Hft}$ concentrated at c. -3.2 confirms this and $\mathrm{Nd}$ and $\mathrm{Hf}$ depleted mantle model ages at c. $1.6 \mathrm{Ga}$ (Pankhurst et al., 2014) which validate the presence of continuously recycled older crustal material in the source region of the Tardugno Granodiorite that could be provided by Mesoproterozoic Haag Nunataks gneiss, likewise as that of the El Jagüelito conglomerate SG09-61.

These tracers indicate the presence of unexposed continental crust in Patagonia having the same age and isotopic signatures as the distinctive Haag Nunataks gneiss in Antarctica. Yet, $\mathrm{Hf}_{\mathrm{DM}}$ model ages with a major age cluster between 1.51 and $1.73 \mathrm{Ga}$ indicate separation from continuously recycled older crustal material in the source region by partial melting (Fig. 18 B), which agrees with major 1.4-1.7 Ga age range of the Sm-Nd (Pankhurst et al., 2006, 2014; Martínez Dopico et al., 2011; Chernicoff et al., 2013) and Re-Os (Mundl et al., 2016; Schilling et al., 2017) crust-derived depleted mantle model ages.

In summary, the $\mathrm{Hf}$ isotope composition of zircon grains of the $\mathrm{El}$ Jagüelito Formation and Tardugno Granodiorite suggest derivation by mixing of juvenile mantle-derived and crustally recycled components of the similar composition to that exposed in Antarctica. It also indicates the presence of similar Mesoproterozoic to Paleoproterozoic sources along conjugate margins that isotopically support a Patagonia-East Antarctic fit.

\subsubsection{Overall similarities of the Archeocyath fauna}

The outcrop of the source area of the Atdabanian-Botomian Archeocyathan limestone blocks of the El Jagüelito Formation is rather puzzling and remains unknown in Patagonia. Since water-transport rapidly rounds large clasts, outsized and angular-shaped blocks normally indicate minimal transport (Haughton et al., 1991). However, considering that in situ archeocyathan limestones have not been reported either in the El Jagüelito Formation and surrounding Patagonian units nor the regions immediately North of Patagonia or even the entire continental South America, a local, proximal source area for outsized calcareous clasts is unlikely (Figs. 20, $21 \mathrm{~A}$ ). Thus, the most likely provenance area should be a parautochthonous source but in East Antarctica (e.g., González et al., 2010, 2011a; Naipauer et al., 2010). For instance, Archeocyathan limestones are found in situ in the inboard Shackleton, Schneider Hills, and Leverett limestones, Nelson Limestone, and Minaret Formation, respectively of Early, Middle and Late Cambrian age of Antarctica (Debrenne and Kruse, 1989; Cooper and Shergold, 1991; Wood et al., 1992; Rowell et al., 1997). Similar archeocyathan limestones occur as erratic blocks in upper Paleozoic tillites and more recent moraines in neighboring regions of West Gondwana, such as the Antarctic Peninsula, the Ellsworth Mts., South Africa, the Malvinas (Falkland) Islands and the newly found location of Sierra de la Ventana in Argentina (González et al., 2012). The Transantarctic Mts., and particularly the Shackleton Limestone, are suggested to be the most likely source area for most of these blocks (Debrenne and Kruse, 1989; Stone and Thomson, 2005; Stone et al., 2012, and references therein).

The specimens described from the El Jagüelito Formation show additional close relationships with the Early Cambrian assemblages reported from the Antarctic Peninsula, the Malvinas (Falkland) Islands and the Whichaway Nunataks, and afterward their fossiliferous limestone clasts could have derived directly from the same Shackleton Limestone of the Central Transantarctic Mts. (González et al., 2011a). Alternatively, a potential source area should be an Archeocyathan limestone within the Leverett Formation in the Bender Mts. of the outboard Queen Maud terrane (Paulsen et al., 2015), which Atdabanian-Botomian Archeocyathids is akin to that of the inboard Shackleton Limestone (Rowell et al., 1997).

Concerning the above overall similarities of the fossiliferous limestone blocks, a special correlation can be established between the c. $510 \mathrm{Ma}$ conglomerate AB-282 level of the El Jagüelito Formation and the c. 506 Ma Douglas Conglomerate/Starshot Formation of the Byrd Group in the Transantarctic Mts. (Goodge et al., 2004), all of which contain coeval archeocyathan limestone clasts of the underlying Shackleton Limestone (Myrow et al., 2002), and Ross magmatic clasts and sharing similar detrital zircon patterns (Naipauer et al., 2010; González et al., 2010, 2011a). Or else, further equivalence in the c. 509 Ma maximum depositional age of the schist with quartzitic pebbles from Fairweather Formation (Paulsen et al., 2015) and even the Conglomerate Ridge Formation with granite clasts dated at $532 \pm 5$ and $525 \pm 2 \mathrm{Ma}$ (Rees et al., 1995), all interpreted as the sedimentary response to uplift and erosion in the source region.

In summary, Archeocyatids are strong provenance markers, and thus, Early Cambrian fossiliferous blocks from the El Jagüelito Formation were probably transferred from inboard Antarctic margin to outboard Patagonian magmatic arc/back-arc system (Fig. 21 A, B).

\subsection{Paleogeographic implications}

Based on all previous results and interpretations, a paleogeographic reconstruction between Patagonia and Antarctica conjugate margins is assessed along a series of geodynamic stages, shown below.

\subsubsection{Early Cambrian (530-515 Ma) synsedimentary volcanism}

By the Early Cambrian time, the onset of active subduction occurs along the paleo-Pacific continental margin of Antarctica (Unrug, 1997; Curtis et al., 1999; Goodge et al., 2004; Estrada et al., 2016). As result of the backward movement of the subduction zone relative to the motion of the Antarctic plate which was being subducted, the overriding plate was stretched, and a back-arc basin was formed towards the continent whereas a volcanic arc was implanted oceanward (Fig. $21 \mathrm{~A}$; see also Huber-Grünberg, 1990). In this geodynamic scenario, the eastern North Patagonian basement can be placed outboard of the continental margin represented by the Pensacola-Queen Maud Mts., and southward of the Ellsworth-Whitmore Mts. block (Fig. 23, see also the paleogeographic position of Patagonia in the Gondwana configuration at $c$. $500 \mathrm{Ma}$, Fig. 15.1 of Schmitt et al., 2018). In connection with periodic extension within the overall convergent-extensional margin system, the successive periods of Cambrian synsedimentary volcanic activity developed, i.e., c. 530 Ma first- and c. 515 Ma second eruptive stages.

\subsubsection{Mid-Cambrian (510-500 Ma) rift-related volcanism}

The extensional back-arc basin subsequently became in a rift-related basin due to progressive subduction of the negatively buoyant oceanic lithosphere and backarc opening via rollback of the forearc block. The arc/back-arc magmatism ceased in Patagonia, and the locus of syn-rift volcanic activity shifted to the Antarctic margin (Boger and Miller, 2004; Paulsen et al., 2007, 2008) in which volcanic eruptions of the third eruptive stage took place (Fig. 21 B). The onset of rifting in Patagonia produced block tilting, footwall uplift of volcanic complexes above base level and erosion by high-angle normal faults, one that affected the 529 Ma Leon eruptive center (Fig. 8). Synchronously but westward in arc-distal positions, new troughs were developed, and protoliths of either the high-grade Colohuincul Complex was deposited (Figs. 21 B, 23) c. $505 \mathrm{Ma}$ (Serra Varela et al., 2016) and the low-grade Colo Niyeu Formation started its deposition younger than 532 Ma (Martínez Dopico et al., 2017).

By $505 \pm 5 \mathrm{Ma}$ (Curtis et al., 2004), the accretion of the outboard Queen Maud suspect terrane with the Antarctic margin of Gondwana caused the orogenic Ross contraction event along the Transantarctic Mts. and Ellsworth Mts. (Rowell and Rees, 1989; Rowell et al., 1992; 
Curtis and Storey, 2003; Curtis et al., 2004; Goodge et al., 2004; Paulsen et al., 2013, 2015; among others).

Broadly synchronous, a back-arc basin inversion concomitant to a pulse of the trench and slab roll-back produced changes in the geodynamic and paleogeography of both, the outboard Patagonian and the inboard Antarctic assemblages. Along Transantarctic Mts., the main Ross tectonic event was responsible for the folding and uplift of the Early-to-Middle Cambrian sedimentary successions (Rowell et al., 1992; Curtis and Storey, 2003; Goodge et al., 2004; Curtis et al., 2004). Large volumes of molassic sediments were shed to marginal MidCambrian to Ordovician Antarctic basins, by erosion of Pan African, Grenville, and cratonic sources, and also of volcanic rocks sourced from Ross magmatic arc (Goodge et al., 2004, 2012; Flowerdew et al., 2007; Goodge et al., 2012; Paulsen et al., 2015, 2016; Estrada et al., 2016; Craddock et al., 2017).

In the outboard northern Patagonia basement, the onset of supracrustal deformation related to the inboard main Ross orogenic event is registered as the sedimentary response to uplift and erosion in the East Antarctic source region. Syn-orogenic deposition of the conglomerate layer AB-282 has provided stratigraphic evidence for the presence of at least localized erosion and possible angular unconformity at some localities, thus indicating tectonically induced denudation in a convergent-margin setting of Gondwana. Thus, Patagonia received archeocyathan limestone and Ross magmatic clasts to contribute to the conglomerate layer AB-282 (Fig. 21 B).

As a result, the accretion of the outboard Queen Maud suspect terrane within the overall convergent-extensional Antarctic margin system (Paulsen et al., 2013, 2015) could have triggered detachment of the outboard assemblage of Patagonia concomitantly, correspondingly to the tectonic instability and transtensional regimes associated with rifting and the oblique-to-normal convergence and rapid plate motion that characterized the entire proto-Pacific region at that time (Encarnación and Grunow, 1996; Boger and Miller, 2004; Cawood, 2005; Paulsen et al., 2008, among others). Thus, Patagonia could have detached from Antarctica shortly after c. 505 Ma.

\subsubsection{Late Cambrian-Early Ordovician orogenesis: the collision of northern} Patagonia

After accretion of the Queen Maud terrane, the major geodynamic scenario was to shift the outboard assemblage of northern Patagonia from the East Antarctica continental margin to the southwest Gondwana margin in South America. The geodynamic scenario can be envisaged as (1) Detachment of magmatic arc-back arc system of northern Patagonia from Antarctica may have started, at least, shortly after Mid-Cambrian. (2) By Late Cambrian-Middle Ordovician, northwestward drifting of northern Patagonia occurred towards the protoPacific margin of Gondwana South America. (3) Docking and collision of northern Patagonia may have occurred during the Furongian to Tremadocian. Although geological and structural evidence point to a Late Paleozoic time of Patagonia accretion to South America (Ramos, 1984, 2008; Ramos and Naipauer, 2014), the geochronologic data presented in this contribution support that final amalgamation of the northern Patagonia basement with South America could have occurred earlier. For instance, the youngest zircon grains from meta-K bentonites, metaconglomerates, and metagreywackes yielded concordant Furongian to Tremadocian ages between 493 and 479 Ma which we interpreted as timing of the regional metamorphism and deformation (see Section 5, Figs. 15 to 17), and therefore this orogenic processes may be ascribed to collision of northern Patagonia against the protoPacific margin of Gondwana South America (Fig. 21 C). Additionally, the 490-470 Ma timing of orogenic events (Pankhurst et al., 2006; Greco et al., 2014, 2017) in high-to-low grade rocks of the Mina Gonzalito Complex and the Nahuel Niyeu Formation respectively is synchronous and thus equivalent as that of the El Jagüelito Formation, corroborating that all Patagonian units belong to a unique orogen (Figs. 20, $21 \mathrm{C})$. This orogeny was discrete and short-lived, as it characterizes the extensional accretionary orogens (Collins, 2002), and is somewhat synchronous with the Early Ordovician Famatinian orogeny from the Sierras Pampeanas of central Argentina (e.g., Sato et al., 2003; Ramos, 2018).

7.6.4. Early Ordovician post-orogenic Punta Sierra Plutonic Complex: postcollisional magmatism

By the Early Ordovician, post-collisional magmatism was implanted on Patagonian margin since, at least, $477 \mathrm{Ma}$, which is the oldest crystallization age to Punta Sierra Plutonic Complex. Undeformed, postorogenic granitoids intruded in a range of 477-462 Ma (Varela et al., 1998, 2008; Pankhurst et al., 2006) the already deformed and metamorphosed basement rocks (Figs. 20, $21 \mathrm{C}$ ).

In the Antarctic counterpart, at Transantarctic Mts., widespread Ross arc plutonism, i.e., Granite Harbor Intrusive Complex (Gunn and Warren, 1962) and the Queen Maud batholith (McGregor, 1965; Murtaugh, 1969; Borg et al., 1990; Stump, 1995) started as early as c. $590 \mathrm{Ma}$ (Goodge et al., 2012). Ages cluster around 500 Ma representing a peak syn-orogenic magmatic pulse whereas younger ages until $480 \mathrm{Ma}$ are related to post-orogenic magmatism (e.g., Encarnación and Grunow, 1996; Grunow and Encarnación, 2000; Allibone and Wysoczanski, 2002 and references therein).

The onset of post-orogenic magmatic activity of the Punta Sierra Plutonic Complex is the roughly coincident overlapping culmination of that correlated to Granite Harbor Intrusive Complex, and thus post-orogenic magmatism is diachronic along Patagonia and Antartica conjugate margins.

\section{Concluding remarks}

Spatial and temporal distribution of K-bentonites beds from northern Patagonia reveal that they can be good marker horizons for lithologic, geochemical and geochronological comparison, and for regional stratigraphic correlations along Early Paleozoic continental magmatic provinces of the paleo-Pacific margin of Gondwana (i.e., between Patagonia and Antarctica conjugate margins).

The El Jagüelito and Nahuel Niyeu formations, and also the Mina Gonzalito Complex, are part of a same outboard volcanosedimentary assemblage which was rifted-off south of the corridor Ellsworth-Withmore Mts.-Pensacola and Queen Maud Mts. sector of the paleo-Pacific margin of East Gondwana during main Ross orogenic event (Fig. 23). Equivalent rocks to the Mesoproterozoic Haag Nunatak gneiss may continue southward of the EllsworthWhitmore block, as the underground Grenville-age continental crust of northern Patagonia. We envisage the outboard supracrustal Cambrian assemblage of the eastern North Patagonian Massif as the volcano-sedimentary cover of the underground "Grenvillian-age" basement rocks.

Finally, the "Patagonia terrane" is considered as not an exotic terrane originally defined by Ramos (1984) which comprises northern and southern Patagonia blocks, but as parautochthonous "suspect terrane" composed of tectonostratigraphic crustal fragments derived from a magmatic arc/back-arc system. Cambrian rifting and detachment of the southern Patagonia block, i.e., Deseado Massif and underground basement of Magellan basin, from Antarctica (Pankhurst et al., 2006; Ramos and Naipauer, 2014) should have occurred synchronously, and subsequently it should have collided with the northern Patagonia block in the Late Paleozoic (e.g., Pankhurst et al., 2006). The parautochthonous northern Patagonia suspect terrane was part of a collage of accreted terranes that arrived along the paleo-Pacific margin of Gondwana in South America during the Early Paleozoic (e.g., Schmitt et al., 2018).

Supplementary data to this article can be found online at https://doi. org/10.1016/j.gr.2018.05.015. 


\section{Acknowledgments}

We would like to express our sincere thanks to people from Sierra Grande area (J.C. Bacciadone, R. León, Mussi and González and their families) all over the wide eastern part of Río Negro province, for allowing us the access to their farms and for their hospitality during our fieldwork. We also thank G. Greco, H. Campos, V. García and S. González for helping field mapping. We are obliged to fruitful discussions and assistance maintained with Dr. Marcos Comerio (UBACONICET). We warmly acknowledge the reviews by W. Huff and V.A. Ramos, which improved the original manuscript greatly. This contribution was supported by grants PI-UNRN-40-A-462 Universidad Nacional de Río Negro and PICT-2015-0787 Ministerio de Ciencia, Tecnología e Innovación Productiva, ANPCyT (FONCYT).

\section{References}

Aceñolaza, F., Miller, H., Toselli, A., 2002. Proterozoic-Early Paleozoic evolution in western South America - a discussion. Tectonophysics 354, 121-137.

Allibone, A.H., Wysoczanski, R., 2002. Initiation of magmatism during the CambrianOrdovician Ross orogeny in southern Victoria Land, Antarctica. Geological Society of America Bulletin 114, 1007-1018.

Arnolds, A., 1952. Aspectos generales de la geología y geomorfología del Distrito de Sierra Grande, Territorio de Río Negro. Revista de la Asociación Geológica Argentina 7 (2), 131-142.

Baier, J., Audétat, A., Keppler, H., 2008. The origin of the negative niobium-tantalum anomaly in subduction zone magmas. Earth and Planetary Science Letters 267 (1-2), 290-300.

Basei, M.A., Varela, R., Passarelli, C., Siga Jr., O., Cingolani, C., Sato, A.M., González, P.D. 2005. The crystalline basement in the north of Patagonia: isotopic ages and regiona characteristics. In: Pankhurst, R., Veiga, G. (Eds.), Gondwana 12: Geological and Biological Heritage of Gondwana, Abstracts. Academia Nacional de Ciencias, Córdoba, Argentina, p. 62

Beavon, R.V., Fitch, F.J., Rast, N., 1961. Nomenclature and diagnostic characters of ignimbrites with reference to Snowdonia. Geological Journal 2 (4), 600-611.

Bish, D.L., Von Dreele, R.B., 1989. Rietveld refinement of non-hydrogen atomic positions in Kaolinite. Clays and Clay Minerals 37, 289-296.

Blundy, J.D., Wood, B.J., 1991. Crystal-chemical controls on the partitioning of Sr and Ba between plagioclase feldspar, silicate melts and hydrothermal solutions. Geochimica et Cosmochimica Acta 55, 193-209.

Boger, S.D., Miller, J. McL, 2004. Terminal suturing of Gondwana and the onset of the RossDelamerian Orogeny: the cause and effect of an Early Cambrian reconfiguration of plate motions. Earth and Planetary Science Letters 219, 35-48.

Borg, S.G., DePaolo, D.J., Smith, B.M., 1990. Isotope structure and tectonics on the central Transantarctic Mountains. Journal of Geophysical Research 95, 6647-6667.

Boutelier, D., Cruden, A., 2013. Slab rollback rate and trench curvature controlled by arc deformation. Geology 41 (8), 911-914.

Bowring, S.A., Schmitz, M.D., 2003. High precision zircon geochronology and the stratigraphic record. In: Hanchar, J.M., Hoskins, P.W.O. (Eds.), Zircon: Experiments, Isotopes, and Trace Element Investigations. Reviews in Mineralogy and Geochemistry vol. 53, pp. 305-326.

Braitsch, O. 1965. Das Palaozoikum von Sierra Grande (Provincia de Río Negro Argentina) und die altkaledonische faltung im ostlichen Andesvordland. Geologische Rundschau 54 (2), 698-714.

Busteros, A., Giacosa, R., Lema, H., 1998. Hoja Geológica 4166-IV, Sierra Grande (Río Negro). IGRM-SEGEMAR, Boletín 241, Buenos Aires (75 pp.).

Cagnoni, M., Linares, E., Ostera, H., Parica, C., Remesal, M., 1993. Caracterización geoquímica de los metasedimentos de la Formación Nahuel Niyeu: Implicancias sobre su proveniencia y marco tectónico. $12^{\circ}$ Congreso Geológico Argentino 1, Mendoza, pp. 281-288.

Caminos, R., 1983. Descripción Geológica de las Hojas 39g, Cerro Tapiluke y 39h, Chipauquil, provincia de Río Negro. Servicio Geológico Nacional, Buenos Aires.

Caminos, R., 2001. Hoja Geológica 4166-I, Valcheta, provincia de Río Negro. Instituto de Geología y Recursos Minerales. Servicio Geológico Minero Argentino, Buenos Aires.

Caminos, R., Llambías, E., 1984. El Basamento Cristalino. In: Ramos, V. (Ed.), Geología y Recursos Naturales de la Provincia de Río Negro. $9^{\circ}$ Congreso Geológico Argentino, Relatorio, Buenos Aires vol. 1(2), pp. 37-63.

Cas, R.A., Wright, J.V., 1991. Subaqueous pyroclastic flows and ignimbrites: an assessment. Bulletin of Volcanology 53 (5), 357-380.

Castillo, P., Fanning, C.M., Pankhurst, R., Hervé, F., Rapela, C., 2017. Zircon O- and Hfisotope constraints on the genesis and tectonic significance of Permian magmatism in Patagonia. Journal of the Geological Society 174 (5), 803-816.

Cawood, P.A., 2005. Terra Australis Orogen: Rodinia breakup and development of the Pacific and lapetus margins of Gondwana during the Neoproterozoic and Paleozoic. Earth-Science Reviews 69, 249-279.

Cerredo, M., López de Luchi, M., 1998. Mamil Choique Granitoids, southwestern North Patagonian Massif, Argentina: magmatism and metamorphism associated with a polyphasic evolution. Journal of South American Earth Sciences 11 (5), 499-515.

Chernicoff, J., Caminos, R., 1996. Estructura y relaciones estratigráficas de la Formación Nahuel Niyeu, Macizo Nordpatagónico oriental, provincia de Río Negro. Revista de la Asociación Geológica Argentina 51 (3), 201-212.
Chernicoff, J., Zappettini, E., Santos, J., McNaughton, N., Belousova, E., 2013. Combined U$\mathrm{Pb}$ SHRIMP and $\mathrm{Hf}$ isotope study of the Late Paleozoic Yaminue Complex, Río Negro Province, Argentina: implications for the origin and evolution of the Patagonia composite terrane. Geoscience Frontiers 4, 37-56.

Collins, W.J., 2002. Nature of extensional accretionary orogens. Tectonics 21 (4), 1024

Collins, A., Pisarevsky, S., 2005. Amalgamating eastern Gondwana: the evolution of the Circum-Indian Orogens. Earth-Science Reviews 71, 229-270.

Cooper, R., Shergold, J., 1991. Paleozoic invertebrates of Antarctica. In: Tingey, R. (Ed.), The Geology of Antarctica. Clarendon Press, Oxford, pp. 455-486.

Cortés, J.M., 1981. El sustrato pre-cretácico del extremo nordeste de la provincia del Chubut. Revista de la Asociación Geológica Argentina 36 (3), 217-235.

Craddock, J., Fitzgerald, P., Konstantinou, A., Neresond, A., Thomas, R., 2017. Detrital zircon provenance of upper Cambrian-Permian strata and tectonic evolution of the Ellsworth Mountains, West Antarctica. Gondwana Res. 45, 191-207.

Curtis, M., 2001. Tectonic history of the Ellsworth Mountains, West Antarctica: reconciling a Gondwana enigma. Geological Society of America Bulletin 113 (7), 939-958.

Curtis, M., Lomas, S., 1999. Late Cambrian stratigraphy of the Heritage Range, Ellsworth Mountains: implications for basin evolution. Antarctic Science 11 (1), 63-77.

Curtis, M.L., Storey, B.C., 2003. Early Palaeozoic near-surface deformation in the Neptune Range, Antarctica: implications for the Ross and Gondwanian orogenies. Journal of the Geological Society, London 160, 629-642.

Curtis, M.L., Leat, P.T., Riley, T.R., Storey, B.C., Millar, I.L, Randall, D.E., 1999. Middle Cambrian volcanism in the Ellsworth Mountains, Antarctica: tectonic implications for the palaeo-Pacific margin of Gondwana. Tectonophysics 304, 275-299.

Curtis, M., Millar, I., Storey, B., Fanning, M., 2004. Structural and geochronological constraints of early Ross orogenic deformation in the Pensacola Mountains, Antarctica. Geological Society of America Bulletin 116 (5/6), 619-636.

Dalla Salda, L., Cingolani, C., Varela, R., 1992. Early Paleozoic orogenic belt of the Andes in southwestern South America: the result of Laurentia-Gondwana collision? Geology 20, 617-620.

Dalla Salda, L., Varela, R., Cingolani, C., 1994. The Rio Chico Paleozoic crystalline complex and the evolution of Northern Patagonia. Journal of South American Earth Sciences 7 (3-4), 377-386.

Dalla Salda, L., Aragón, E., Benialgo, A., Abre, P., Pezzotti, C., 2003a. El protolito siliciclástico de las Ectinitas El Jaguelito, provincial de Río Negro. Revista de la Asociación Geológica Argentina 58 (3), 321-328.

Dalla Salda, L., Aragón, E., Benialgo, A., Pezzotti, C., 2003b. Una plataforma calcárea en el Complejo Mina Gonzalito, provincia de Río Negro. Revista de la Asociación Geológica Argentina 58 (2), 209-217.

Dalla Salda, L., Zimmermann, U., Abre, P., 2005. Provenance of metamorphic rocks from the Gonzalito District. $16^{\circ}$ Congreso Geológico Argentino, Actas 1, La Plata, Buenos Aires, pp. 915-920.

de Alba, E., 1964. Descripción Geológica de la Hoja 41j, Sierra Grande (Provincia de Río Negro). Dirección Nacional de Geología y Minería, Boletín N 97, Buenos Aires (67pp.).

Debrenne, F., 2007. Lower Cambrian archaeocyathan bioconstructions. Comptes Rendus Palevol 6, 5-19.

Debrenne, F., Kruse, P.D., 1989. Cambrian Antarctic archaeocyaths. In: Crame, J.A. (Ed.), Origin and Evolution of the Antarctic Biota. Geological Society, London, Special Publications vol. 47, pp. $15-28$

Dokuz, A., Tanyolu, E., Genc, S., 2006. A mantle- and lower crust-derived bimodal suite in the Yusufeli (Artvin) area, NE Turkey: trace element and REE evidence for subduction-related rift origin of Early Jurassic Demirkent intrusive complex. International Journal of Earth Sciences 95, 370-394.

Downs, R.T., Bartelmehs, K.L., Gibbs, G.V., Boisen Jr., M.B., 1993. Interactive software for calculating and displaying X-ray or neutron powder diffractometer patterns of crystalline materials. American Mineralogist 78, 1104-1107.

Eby, G.N., 1992. Chemical subdivision of the A-type granitoids: petrogenetic and tectonic implications. Geology 20 (7), 641-644.

Encarnación, J., Grunow, A., 1996. Changing magmatic and tectonic styles along the paleoPacific margin of Gondwana and the onset of early Paleozoic magmatism in Antartica. Tectonics 15 (6), 1325-1341.

Encarnación, J., Rowell, A.J., Grunow, A.M., 1999. A U-Pb age for the Middle Cambrian Taylor Formation, Antarctica: implications for the Cambrian time scale. Journal of Geology $107,497-504$

Eslinger, E., Highsmith, P., Albers, D., de Mayo, B., 1979. Role of iron reduction in the conversion of smectite to illite in bentonites in the disturbed belt, Montana. Clays and Clay Minerals 27, 327-338.

Estrada, S, Läufer, A., Eckelmann, K., Hofmann, M., Gärtner, A. Linnemann, U., 2016. Continuous Neoproterozoic to Ordovician sedimentation at the East Gondwana margin implications from detrital zircons of the Ross Orogen in northern Victoria Land, Antarctica. Gondwana Research 37, 426-448.

Flowerdew, M.J., Millar, I.L., Curtis, M.L., Vaughan, A.P.M., Horstwood, M.S.A., Whitehouse, M.J., Fanning, C.M., 2007. Combined U-Pb geochronology and Hf geochemistry of detrital zircons of early Paleozoic sedimentary rocks, Ellsworth-Whitmore Mountains block, Antarctica. Geological Society of America Bulletin 119, 275-288.

Forsythe, R., 1982. The Late Paleozoic to the Early Mesozoic evolution of Southern South America: a plate tectonic interpretation. Journal of the Geological Society 139, 671-682.

Frey, M., Robinson, D., 1999. Low-grade Metamorphism. Blackwell Science Ltd., Oxford (313 pp.).

García, V., González, S., Tassinari, C., Sato, K., Sato, A.M., González, P.D., Varela, R., 2014. U/ $\mathrm{Pb}$ and Nd data from Peñas Blancas Pluton, Northpatagonian Massif, Argentina. 9th South American Symposium on Isotope Geology, Program and Abstracts, No. 190, San Pablo, Brasil.

García, V., Sato, A., González, P.D., Basei, M., 2015. Geología, geoquímica y geocronología del plutón La Laguna, Macizo Nordpatagónico, Río Negro. $3^{\circ}$ Simposio sobre 
Petrología Ígnea y Metalogénesis Asociada, Acta Resúmenes, General Roca, Río Negro, pp. 73-74.

Gelós, E., Schillizzi, R., Spagnuolo, J., 1990. Interpretación litoestratigráfica de un tramo de costa al Sur de Punta Pórfido, Provincia de Río Negro. Revista de la Asociación Geológica Argentina 45 (3-4), 397-402.

Giacosa, R., 1987. Caracterización de un sector del basamento metamórfico-migmatítico en el extremo suroriental del Macizo Nordpatagónico, Provincia de Río Negro. $10^{\circ}$ Congreso Geológico Argentino 3, S. M. de Tucumán, pp. 51-54.

Giacosa, R., 1993. El ciclo eruptivo Gondwánico en el área de Sierra de Pailemán, Macizo Norpatagónico, Argentina. $12^{\circ}$ Congreso Geológico Argentino y $2^{\circ}$ Congreso de Exploración de Hidrocarburos 4, Buenos Aires, pp. 113-119.

Giacosa, R., 1994. El basamento Precámbrico del sector oriental del Macizo Norpatagónico, Argentina. Zentralblatt für Geologie und Paläontologie 1 (1-2), 89-100.

Giacosa, R., 1997. Geología y petrología de las rocas pre-cretácicas de la región de Sierra Pailemán, Provincia de Río Negro. Revista de la Asociación Geológica Argentina 52 (1), 65-80.

Giacosa, R., Paredes, J., 2001. Estructura de las metamorfitas del Paleozoico temprano en el Arroyo Salado. Macizo Norpatagónico, Río Negro. Revista de la Asociación Geológica Argentina 56 (2), 141-149.

Gibson, S., Thompson, R., Leat, P., Morrison, M., Hendry, G., Dickin, A., Mitchell, j., 1993. Ultrapotassic magmas along the flanks of the Oligo-Miocene Rio Grande Rift, USA: monitors of the zone of lithospheric mantle extension and thinning beneath a continental rift. Journal of Petrology 34 (1), 187-228.

Gifkins, C., Herrmann, W., Large, R., 2005a. Altered Volcanic Rocks. A Guide to Description and Interpretation. CODES Key Centre, University of Tasmania (275 pp.).

Gifkins, C., Allen, R., McPhie, J., 2005b. Apparent welding textures in altered pumice-rich rocks. Journal of Volcanology and Geothermal Research 142 (1-2), 29-47.

González, P.D., Poiré, D., Varela, R., 2002. Hallazgo de trazas fósiles en la Formación El Jagüelito y su relación con la edad de las metasedimentitas, Macizo Norpatagónico Oriental, Río Negro. Revista de la Asociación Geológica Argentina 57 (1), 35-44.

González, P., Varela, R., Sato, A., Campos, H., Greco, G., Naipauer, M., Llambías, E., García, V., 2008a. Metamorfismo regional Ordovícico y estructura de la Ectinita El Jagüelito al SO de Sierra Grande, Río Negro. $17^{\circ}$ Congreso Geológico Argentino 2, San Salvador de Jujuy, pp. 849-850.

González, P.D., Varela, R., Sato, A.M., Llambias, E., González, S., 2008b. Dos fajas estructurales distintas en el Complejo Mina Gonzalito (Río Negro). $17^{\circ}$ Congreso Geológico Argentino 2, S.S. de Jujuy, pp. 847-848.

González, P.D., Sato, A.M., Varela, R., Llambias, E., Naipauer, M., Basei, M., Campos, H., Greco, G., 2008c. El Molino Pluton: granite with regional metamorphism within El Jagüelito Formation, North Patagonian Massif. 6th South American Symposium on Isotope Geology, S. C. de Bariloche (Short Papers Volume CD, Paper 41, 4 pp.).

González, P.D., Varela, R., Sato, A.M., Greco, G., Naipauer, M., Llambias, E., 2010. Evidencias geológicas y paleontológicas en la Formación El Jagüelito para la conexión PatagoniaAntártida durante el Paleozoico inferior. $10^{\circ}$ Congreso Argentino de Paleontología y Bioestratigrafía y $7^{\circ}$ Congreso Latinoamericano de Paleontología. Resumen 24, La Plata, Buenos Aires, p. 48

González, P., Tortello, M., Damborenea, S., 2011a. Early Cambrian archeocyathan limestone blocks in low-grade meta-conglomerate from El Jagüelito Formation (Sierra Grande, Río Negro, Argentina). Geologica Acta 9 (2), 159-173.

González, P.D., Sato, A.M., Naipauer, M., Varela, R., Llambías, E., Basei, M.A.S., Sato, K., Sproesser, W., 2011b. Does Patagonia represent a missing piece detached from the Ross Orogen? In: Schmitt, R.S., et al. (Eds.), Gondwana 14: Reuniting Gondwana: East Meets West, Rio de Janeiro, Brasil, Abstracts, p. 153

González, P., Greco, G., Varela, R., Naipauer, M., Sato, A.M., Llambías, E., García, V., Campos, H., 2011c. Patrón metamórfico invertido en la Formación El Jagüelito de la Herradura del Salado, basamento Norpatagónico, Río Negro. $18^{\circ}$ Congreso Geológico Argentino, Neuquén, pp. 85-86.

González, P.D., Tortello, M., Damborenea, S., Naipauer, M., Sato, A.M., Varela, R., 2012. The Archaeocyaths from South America: review and a new record. Geological Journal 48 (2-3), 114-125.

González, P.D., Sato, A., Varela, R., Naipauer, M., Llambías, E., Castro Dorado, A., 2013. Volcanismo de arco asociado a la Formación El Jagüelito, Sierra Grande, Río Negro. $2^{\circ}$ Simposio de Petrología Ignea y Metalogénesis Asociada, Resumen, San Luis, pp. 39-40.

González, P.D., Sato, A.M., Varela, R., Greco, G., Naipauer, M., Llambías, E., Basei, M., 2014 Metamorfismo y estructura interna de la Formación El Jagüelito en el arroyo Salado Inferior, Macizo Norpatagónico, Río Negro. $19^{\circ}$ Congreso Geológico Argentino, Córdoba, pp. T8-22 (CD).

González, S.N., Greco, G.A., González, P.D., Sato, A.M., Llambías, J.E., Varela, R., Basei, M.A.S. 2014. Geología, petrografía y edad U-Pb de un enjambre longitudinal NO-SE de diques del Macizo Nordpatagónico Oriental, Río Negro. Revista de la Asociación Geológica Argentina 71 (2), 174-183.

González, S., Greco, G., González, P.D., Sato, A.M., Llambias, E., Varela, R., 2016. Geochemistry of a Triassic dike swarm in the North Patagonian Massif, Argentina. Implications for a post-orogenic event of the Permian Gondwanide Orogeny. Journal of South American Earth Sciences 70, 69-82.

González, P.D., Sato, A.M., Naipauer, M., Varela, R., Basei, M.A.S., Vlach, S.R.F., Chemale, F., Castro Dorado, A., 2018. Early Paleozoic structural and metamorphic evolution of the extra-Andean northern Patagonia basement related to Gondwana assembly (in preparation)

Goodge, J., Williams, I., Myrow, P., 2004. Provenance of Neoproterozoic and lower Paleozoic siliciclastic rocks of the central Ross orógeno, Antarctica: a detrital record of rift-, passive- and active-margin sedimentation. Geological Society of America Bulletin 116 $(9 / 10), 1253-1279$

Goodge, J., Vervoort, J., Fanning, C., Brecke, D., Farmer, G., Williams, I., Myrow, P., DePaolo, D., 2008. A positive test of East Antarctica-Laurentia juxtaposition within the Rodinia Supercontinent. Science 321, 235-240.
Goodge, J.W., Fanning, C.M., Norman, M.D., Bennett, V.C., 2012. Temporal, isotopic and spatial relations of early Paleozoic Gondwana-margin arc magmatism, central Transantarctic Mountains, Antarctica. Journal of Petrology 53, 2027-2065.

Gorton, M., Schandle, E., 2000. From continents to island arcs: a geochemical index of tectonic setting for arc-related and within-plate felsic to intermediate volcanic rocks. The Canadian Mineralogist 38, 1065-1073.

Gozalvez, M.R., 2009. Petrografía y edad ${ }^{40} \mathrm{Ar} /{ }^{39} \mathrm{Ar}$ de leucogranitos peraluminosos al oeste de Valcheta: Macizo Nordpatagónico (Río Negro). Revista de la Asociación Geológica Argentina 64, 285-294.

Greco, G.A., González, S.N., Sato, A.M., González, P.D., Llambías, E.J., Basei, M.A.S., 2014 Nueva datación en circones detríticos para el Complejo Mina Gonzalito, Provincia de Río Negro. $19^{\circ}$ Congreso Geológico Argentino, Córdoba, pp. 1454-1455 (Actas en CD).

Greco, G.A., González, P.D., González, S.N., Sato, A.M., Basei, M.A.S., Tassinari, C.C.G., Sato, K., Varela, R., Llambías, E.J., 2015. Geology, structure, and age of the Nahuel Niyeu Formation in the Aguada Cecilio area, North Patagonian Massif, Argentina. Journal of South American Earth Sciences 62, 12-32.

Greco, G., González, S., Sato, A.M., González, P.D., Basei, M., Llambiás, E., Varela, R., 2017. The Nahuel Niyeu basin: a Cambrian forearc basin in the eastern North Patagonian Massif. Journal of South American Earth Sciences 79, 111-136.

Gregori, D., Kostadinoff, L., Strazzere, A., 2008. Tectonic significance and consequences of the Gondwanide orogeny in northern Patagonia, Argentina. Gondwana Research 14 429-450.

Gregori, D., Kostadinoff, J., Alvarez, G., Raniolo, A., Strazzere, L., Martinez, J.C., Barros, M., 2013. Preandean geological configuration of the eastern North Patagonian Massif, Argentina. Geoscience Frontiers 693-708.

Gromet, L.P., Dymek, R.F., Haskin, L.A., Korotev, R.L., 1984. The "North American shale composite": its compilation, major and trace element characteristics. Geochimica et Cosmochimica Acta 48, 2469-2482.

Grunow, A., Encarnación, J., 2000. Cambro-Ordovician palaeomagnetic and geochronologic data from southern Victoria Land, Antarctica: revision of the Gondwana apparent polar wander path. Geophysical Journal International 141, 391-400.

Gunn, G.M., Warren, G., 1962. Geology of Victoria Land between the Mawson and Mullock Glaciers, Antarctica. New Zealand Geological Survey Bulletin 71, 157.

Hastie, A.R., Kerr, A.C., Pearce, J.A., Mitchell, S.F., 2007. Classification of altered volcanic island arc rocks using immobile trace elements: development of the Th-Co discrimination diagram. Journal of Petrology 48, 2341-2357.

Haughton, P., Todd, S., Morton, A., 1991. Sedimentary provenance studies. In: Morton, A.C., Todd, S.P., Haughton, P.D.W. (Eds.), Developments in Sedimentary Provenance Studies. Geological Society Special Publication No. 57, pp. 1-11.

Hervé, F., Haller, M., Duhart, P., Fanning, M., 2005. SHRIMP U-Pb ages of detrital zircons from Cushamen and Esquel formations, North Patagonian Massif, Argentina: geological implications. $15^{\circ}$ Congreso Geológico Argentino 1, La Plata (Buenos Aires), pp. 309-314.

Hill, D., 1972. Part E (revised), 1. Archaeocyatha. In: Teichert, C. (Ed.), Treatise on Invertebrate Paleontology. The Geological Society of America and the University of Kansas, Boulder, Colorado (158 pp.).

Hoskin, P., Schaltegger, U., 2003. The composition of zircon and igneous and metamorphic petrogenesis. Reviews in Mineralogy and Geochemistry 53 (1), 123-142.

Huber-Grünberg, A., 1990. Sedimentologie, Fazies und Herkunft der kambrisch/ ordovizischen und silurisch/unterdevonischen Einheiten von Sierra Grande, Patagonien. Ludwig-Maximilian Universitat, Munich (Ph D Dissertation, 196 pp.).

Huff, W., 2008. Ordovician K-bentonites: issues in interpreting and correlating ancient tephras. Quaternary International 178, 276-287.

Huff, W., 2016. K-bentonites: a review. American Mineralogist 101, 43-70.

Huff, W., Türkmenoglu, A., 1981. Chemical characteristics and origin of Ordovician Kbentonites along the Cincinnati arch. Clays and Clay Minerals 29, 113-123.

Huff, W., Müftüoglu, E., Kolata, D.R., Bergström, S.M., 1999. K-bentonite bed preservation and its event stratigraphic significance. Acta Universitatis Carolinae, Geologica 43, 491-493.

Jacobs, J., Thomas, R., 2004. Himalayan-type indenter-escape tectonics model for the southern part of the late Neoproterozoic-early Paleozoic East African-Antarctic orogen. Geology 32 (8), 721-724.

James, N.P., Debrenne, F., 1981. Lower Cambrian bioherms: pioneer reefs of the Phanerozoic. Acta Palaeontologica Polonica 25 (3-4), 655-668.

Japas, S., 2001. Modelo cinemático neopaleozoico para el sector nororiental del Macizo Norpatagónico, Argentina. Journal of Iberian Geology 27, 91-121.

Keller, R., Fisk, M., Smellie, J., Strelin, J., Lawver, L., White, W., 2002. Geochemistry of backarc basin volcanism in Bransfield Strait, Antarctica: subducted contributions and along-axis variations. Journal of Geophysical Research 107 (B8), 1-17 (ECV 4).

Keller, C., Schoene, B., Barboni, M., Samperton, K., Husson, J., 2015. Volcanic-plutonic parity and the differentiation of the continental crust. Nature 523, 301-307.

Klewin, K., Shirey, S., 1992. The igneous petrology and magmatic evolution of the Midcontinent rift system. Tectonophysics 213, 33-40.

Lallemand, S., Heuret, A., Faccenna, C., Funiciello, F., 2008. Subduction dynamics as revealed by trench migration. Tectonics 27 (3), 1-15 (Tc3014).

Lardeaux, J.M., 2014. Deciphering orogeny: a metamorphic perspective. Examples from European Alpine and Variscan belts. Part I: Alpine metamorphism in the western Alps. A review. Bulletin de la Societe Geologique de France 185 (2), 93-114.

Leat, P., Jackson, S., Thorpe, R., Stillman, C., 1986. Geochemistry of bimodal basaltsubalkaline/peralkaline rhyolite provinces within the Southern British Caledonides. Journal of the Geological Society 143, 259-273.

Igneous Rocks: A Classification and Glossary of Terms. In: Le Maitre, R. (Ed.), Recommendations of the International Union of Geological Sciences Subcommission on the Systematics of Igneous Rocks. Cambridge University Press, Cambridge (252p).

López de Luchi, M., Cerredo, M.E., 2008. Geochemistry of the Mamil Choique granitoids at Rio Chico, Río Negro, Argentina: Late Paleozoic crustal melting in the North Patagonian Massif. Journal of South American Earth Sciences 25, 526-546. 
López de Luchi, M., Wemmer, K., Rapalini, A., 2008. The cooling history of the North Patagonian Massif: first results for the granitoids of the Valcheta area, Río Negro, Argentina. $6^{\circ}$ South American Symposium on Isotope Geology, Abstract 33.

López de Luchi, M., Rapalini, A., Tomezzoli, R., 2010. Magnetic fabric and microstructures of Late Paleozoic granitoids from the North Patagonian Massif: evidence of a collision between Patagonia and Gondwana? Tectonophysics 494 (1-2), 118-137.

Ludden, J., Gélinas, L., Trudel, P., 1982. Archean metavolcanics from the Rouyn-Noranda district, Abitibi Greenstone Belt, Quebec. 2. The mobility of trace elements and petrogenetic constraints. Canadian Journal of Earth Sciences 19 (12), 2276-2287.

Macdonald, R., 1974. Nomenclature and petrochemistry of the peralkaline oversaturated extrusive rocks. Bull. Volcanol. 38, 498-516.

Malvicini, L., Llambías, E., 1974. Geología y génesis del depósito de manganeso Arroyo Verde, provincia del Chubut, República Argentina. $5^{\circ}$ Congreso Geológico Argentino 2, Villa Carlos Paz, pp. 185-202.

Manceñido, M.O., Damborenea, S.E., 1984. Megafauna de Invertebrados Paleozoicos y Mesozoicos. In: Ramos, V. (Ed.), Geología y Recursos Naturales de la Provincia de Río Negro. $9^{\circ}$ Congreso Geológico Argentino, San Carlos de Bariloche, pp. 413-465 Relatorio 2(5).

Marker, P., 2005. What is a K-bentonite? Geological Society of America Abstracts With Programs vol. 37(7), p. 143

Martínez Dopico, C., López de Luchi, M., Rapalini, A., Kleinhanns, I., 2011. Crustal segments in the North Patagonian Massif, Patagonia: an integrated perspective based on Sm-Nd isotope systematics. Journal of South American Earth Sciences 31, 324-341.

Martínez Dopico, C., López de Luchi, M., Rapalini, A., Hervé, F., Fuentes, F., Fanning, M. 2017. U-Pb SHRIMP dating of detrital zircon grains of the Colo Niyeu Formation: extending the latest Neoproterozoic to Cambrian peri-Gondwana realm into the centra North Patagonian Massif. 20 Congreso Geológico Argentino S-15, Tucumán, pp. 66-72.

McGregor, V.R., 1965. Geology of the area between the Axel Heiberg and Shackleton Glaciers, Queen Maud Range, part 1-basement complex, structure and glacial geology. New Zealand Journal of Geology and Geophysics 8, 314-343.

McPhie, J., Doyle, M., Allen, R., 1993. Volcanic Textures. A Guide to the Interpretation of Textures in Volcanic Rocks. CODES Key Centre, University of Tasmania (198 pp.).

Meert, J., 2003. A synopsis of events related to the assembly of eastern Gondwana. Tectonophysics 362, 1-40.

Meert, J., Liberman, B., 2008. The Neoproterozoic assembly of Gondwana and its relationship to the Ediacaran-Cambrian radiation. Gondwana Research 14, 5-21.

Merriman, R.J., Peacor, D.R., 1999. Very low-grade metapelites; mineralogy, microfabrics and measuring reaction progress. In: Frey, M., Robinson, D. (Eds.), Low-grade Metamorphism. Blackwell Sciences Ltd., Oxford., pp. 10-60.

Millar, I.L., Pankhurst, R.J., 1987. Rb-Sr geochronology of the region between the Antarctic Peninsula and the Transantarctic Mountains: Haag Nunataks and Mesozoic granitoids. In: McKenzie, G.D. (Ed.), Gondwana Six: Structure, Tectonics, and Geophysics. Geophysical Monograph vol. 40. American Geophysical Union, pp. 151-160.

Millar, I.L., Storey, B.C., 1995. Early Palaeozoic rather than Neoproterozoic volcanism and rifting within the Transantarctic Mountains. Journal of the Geological Society, London $152,417-420$.

Moore, D., Reynolds, R., 1997. X-ray Diffraction and the Identification an Analysis of Clay Minerals. Oxford University Press, New York (378 pp.).

Morrison, G., 1980. Characteristics and tectonic setting of the shoshonite rock association. Lithos 13, 97-108.

Müller, H., 1965. Zur Alterfrage der eisenerzlagerstätte Sierra Grande/Río Negro in Nordpatagonien Aufgrund neuer Fossilfunde. Geologische Rundschau 54, 715-732.

Mundl, A., Ntaflos, T., Ackerman, L., Bizimis, M., Bjerg, E.A., Wegner, W., Hauzenberger, C.A., 2016. Geochemical and Os-Hf-Nd-Sr isotopic characterization of North Patagonian Mantle Xenoliths: implications for extensive melt extraction and percolation processes. Journal of Petrology 57, 685-715.

Münker, C., Crawford, A., 2000. Cambrian arc evolution along the SE Gondwana active margin: a synthesis from Tasmania-New Zealand-Australia-Antarctica correlations. Tectonics 19 (3), 415-432.

Münker, C., Wörner, G., Yogodzinski, G., Churikova, T., 2004. Behavior of high field strength elements in subduction zones: constraints from Kamchatka-Aleutian arc lavas. Earth and Planetary Science Letters 224, 275-293.

Murphy, J.B., 2007. Igneous rock associations 8. Arc magmatism II: geochemical and isotopic characteristics. Journal of the Geological Association of Canada 34 (1) (Geoscience Canada)

Murtaugh, J.G., 1969. Geology of the Wisconsin Range batholith, Transantarctic mountains. New Zealand Journal of Geology and Geophysics 12, 526-550.

Myrow, P., Pope, M., Goodge, J., Fischer, W., Palmer, A., 2002. Depositional history of pre-Devonian strata and timing of Ross orogenic tectonism in the centra Transantarctic Mountains, Antarctica. Geological Society of America Bulletin 114 (9), 1070-1088.

Naipauer, M., Sato, A.M., González, P.D., Chemale Jr., F., Varela, R., Llambías, E., Greco, G. Dantas, E., 2010. Eopaleozoic Patagonia-East Antarctica connection: fossil and U-Pb evidence from El Jagüelito Formation. $7^{\circ}$ South American Symposium on Isotope Geology, Brasilia, pp. 602-605 (Short Papers Volume (CD))

Naipauer, M., González, P.D., Sato, A.M., Varela, R., Llambías, E., Manassero, M., 2011. U-Pb and Lu-Hf zircon (SHRIMP-LA-ICPMS-MC) analyses of Cambrian and SilurianDevonian sequences of Northeastern Patagonia: its tie-up with southern Gondwana. Gondwana 14: East Meets West, Abstracts, Rio de Janeiro, Brasil (1 p.).

Nakamura, N., 1974. Determination of REE, Ba, Fe, Mg, Na, and $\mathrm{K}$ in carbonaceous and ordinary chondrites. Geochimica et Cosmochimica Acta 38, 757-775.

Németh, K., Pécskay, S., Martin, U., Gméling, K., Molnár, F., Cronin, S., 2008. Hyaloclastites, peperites and soft-sediment deformation textures of a shallow subaqueous Miocen rhyolitic dome-cryptodome complex, Pálháza, Hungary. Geological Society, London, Special Publications 302, 63-86.
Núñez, E., Bachmann, E.W., R, I., Britos, A., Franchi, M., Lizuaín, A., Sepúlveda, E., 1975. Rasgos geológicos del sector oriental del Macizo Somuncura, provincia de Río Negro, República Argentina. $2^{\circ}$ Congreso Iberoamericano de Geología Económica, Buenos Aires, pp. 247-266.

Ogg, J.G., Ogg, G.M., Gradstein, F.M., 2016. A Concise Geologic Time Scale 2016. Elsevier, Amsterdam (234 pp.)

Pankhurst, R.J., Storey, B.C., Millar, I.L., Macdonald, D.I., Vennum, W.R., 1988. CambrianOrdovician magmatism in the Thiel Mountains, Transantarctic Mountains, and implications for the Beardmore orogeny. Geology 16, 246-249.

Pankhurst, R.J., Rapela, C., Loske, W., Márquez, M., Fanning, C., 2003. Chronological study of the pre-Permian basement rocks of southern Patagonia. Journal of South American Earth Sciences 16, 27-44.

Pankhurst, R.J., Rapela, C.W., Fanning, C.M., Márquez, M., 2006. Gondwanide continental collision and the origin of Patagonia. Earth-Science Reviews 76, 235-257.

Pankhurst, R.J., Rapela, C.W., López de Luchi, M.G., Rapalini, A.E., Fanning, C.M., Galindo, C., 2014. The Gondwana connections of northern Patagonia. Journal of the Geological Society $171,313-328$.

Park, G., 2018. Mountains: The Origins of the Earth's Mountain Systems. Dunedin Academic Press, Edinburgh, Scotland (528 pp.)

Paulsen, T., Encarnación, J., Grunow, A., Layer, P., Watkey, M., 2007. New age constraints for a short pulse in Ross orogen deformation triggered by East-West Gondwana suturing. Gondwana Research 12, 417-427.

Paulsen, T., Encarnación, J., Grunow, A., Valencia, V., Rasoazanamparany, 2008. Late sinistral shearing along Gondwana's Paleo-Pacific margin in the Ross orogen, Antartica: new structure and age data from the O'Brien Peak area. The Journal of Geology 116, 303-312.

Paulsen, T., Encarnación, J., Grunow, A., Valencia, V., Pecha, M., Layer, P., Rasoazanamparany, P., 2013. Age and significance of 'outboard' high-grade metamorphics and intrusives of the Ross orogen, Antarctica. Gondwana Research 24, 349-358.

Paulsen, T., Encarnación, J., Grunow, A., Valencia, V., Layer, P., Pecha, M., Stump, E., Roeske, S., Thao, S., Rasoazanamparany, C., 2015. Detrital mineral ages from the Ross Supergroup, Antarctica: implications for the Queen Maud terrane and outboard sediment provenance on the Gondwana margin. Gondwana Research 27, 377-391.

Paulsen, T., Deering, C., Sliwinski, J., Bachmann, O., Guillong, M., 2016. Detrital zircon ages from the Ross Supergroup, north Victoria Land, Antarctica: implications for the tectonostratigraphic evolution of the Pacific-Gondwana margin. Gondwana Research 35, 79-96.

Pearce, J.A., Norry, M.J., 1979. Petrogenetic implications of Ti, Zr, Y and Nb variations in volcanic rocks. Contributions to Mineralogy and Petrology 69, 33-47.

Pearce, J.A., Stern, R.J., 2006. Origin of back-arc basin magmas: trace element and isotope perspectives. In: Christie, D., Fisher, Ch., Lee, Sang-Mook, Givens, S. (Eds.), Back-arc Spreading Systems: Geological, Biological, Chemical, and Physical Interactions. American Geophysical Union, Geophysical Monograph Series vol. 166, pp. 63-86.

Pearce, J.A., Harris, N.B., Tindle, A.G., 1984. Trace element discrimination diagrams for the tectonic interpretation of granitic rocks. Journal of Petrology 25, 956-983.

Pearce, J.A., Baker, P.E., Harvey, P.K., Luff, I.W., 1995. Geochemical evidence for subduction fluxes, mantle melting and fractional crystallization beneath the South Sandwich island arc. Journal of Petrology 36, 1073-1109.

Perry Jr., E.A., Giekes, J.M., Lawrence, J.F., 1976. Mg, Ca and 018/O TM exchange in the sediment-pore water system, Hole 149, DSDP. Geochimica et Cosmochimica Acta 40, 413-423

Poppe, L.J., Paskevich, V.F., Hathaway, J.C., Blackwood, D.S., 2000. A laboratory manual for X-ray powder diffraction. Kaolinite Group. U. S. Geological Survey Open-File Report 01-041. Woods Hole Field Center, Woods Hole, MA Website:. https://pubs.usgs. gov/of/2001/of01-041/htmldocs/clays/kaogr.htm.

Raigemborn, M.S., Gómez Peral, L., Krause, J., Matheos, S., 2014. Controls on the clay mineral assemblages in an early Paleogene nonmarine succession: implications for the volcanic and paleoclimatic record of Extra-Andean Patagonia, Argentina. Journal of South American Earth Sciences 52, 1-23.

Ramos, V.A., 1975. Geología del sector oriental del Macizo Nordpatagónico entre Aguada Capitán y la Mina Gonzalito, provincia de Río Negro. Revista de la Asociación Geológica Argentina 30, 274-285.

Ramos, V.A., 1984. Patagonia: ¿un continente Paleozoico a la deriva? $9^{\circ}$ Congreso Geológico Argentino 2, San Carlos de Bariloche, pp. 311-325

Ramos, V.A., 2004. Cuyania, an exotic block to Gondwana: review of historical success and the present problems. Gondwana Research 7 (4), 1009-1026.

Ramos, V.A., 2008. Patagonia: a Paleozoic continent adrift? Journal of South American Earth Sciences 26, 235-251.

Ramos, V.A., 2018. The Famatinian Orogen along the protomargin of Western Gondwana: Evidence for a nearly continuous Ordovician magmatic arc between Venezuela and Argentina. In: Folguera, A., et al. (Eds.), The Evolution of the Chilean-Argentinean Andes. Springer Earth System Sciences, pp. 133-161.

Ramos, V.A., Naipauer, M., 2014. Patagonia: where does it come from? Journal of Iberian Geology 40 (2), 367-379.

Ramos, V.A., Jordan, T.E., Allmendinger, R.W., Mpodozis, C., Kay, S.M., Cortés, J.M., Palma, M.A., 1986. Paleozoic Terranes of the Central Argentine Chilean Andes. Tectonics 5, $855-880$

Ramos, V.A., Dallmeyer, R.D., Vujovich, G., 1998. Time constraints on the Early Palaeozoic docking of the Precordillera, central Argentina. Geological Society 142. Special Publications, London, pp. 143-158.

Ramos, V.A., Riccardi, A.C., Rolleri, E.O., 2004. Límites naturales del norte de la Patagonia. Revista de la Asociación Geológica Argentina 59 (4), 785-786.

Rapalini, A., 1998. Syntectonic magnetization of the mid-Paleozoic Sierra Grande Formation: further constraints on the tectonic evolution of Patagonia. Journal of the Geological Society $155,105-114$. 
Rapalini, A., López de Luchi, M., Martínez Dopico, C., Lince Klinger, F., Giménez, M. Martínez, P., 2010. Did Patagonia collide with Gondwana in the Late Paleozoic? Some insights from a multidisciplinary study of magmatic units of the North Patagonian Massif. Geologica Acta 8 (4), 349-371.

Rapalini, A.E., López de Luchi, M., Tohver, E., Cawood, P.A., 2013. The South American ancestry of the North Patagonian Massif: geochronological evidence for an autochthonous origin? Terra Nova 25, 337-342.

Rees, M.N., Duebendorfer, E.M., Wallin, E.T., Thorstenson, D.J., 1995. The EllsworthWhitmore mountains terrane of Antarctica: record of a Neoproterozoic-Cambrian active tectonic margin. $7^{\circ}$ International Symposium on Antarctic Earth Sciences, Abstracts, Siena, p. 322.

Rees, M.N., Smith, E.I., Keenan, D.L., Duebendorfer, E.M., 1997. Cambrian magmatic rocks of the Ellsworth Mountains, West Antarctica. Antarctic Journal of the United States, Review 1997. Marine and Terrestrial Geology and Geophysics, pp. 3-5.

Rollinson, H.R., 1993. Using Geochemical Data: Evaluation, Presentation, Interpretation. Longman/Wyllie, Harlow/New York.

Rowell, A., Rees, M., 1989. Early Palaeozoic history of the upper Beardmore Glacier area: implications for a major Antarctic structural boundary within the Transantarctic Mountains. Antarctic Science 1 (3), 249-260.

Rowell, A.J., Rees, M.N., Evans, K.R., 1992. Evidence of major Middle Cambrian deformation in the Ross orogen, Antarctica. Geology 20, 31-34.

Rowell, A.J., Gonzales, D.A., McKenna, L.W., Evans, K.R., Stump, E., Van Schmus, W.R., 1997. Lower Paleozoic rocks in the Queen Maud Mountains: revised ages and significance. In: Ricci, C.A. (Ed.), The Antarctic Region: Geological Evolution and Processes. Terra Antarctica Publication, Siena, pp. 201-207.

Rowell, A.J., Van Schmus, W.R., Storey, B.C., Fetter, A.H., Evans, K.R., 2001. Latest Neoproterozoic to mid-Cambrian age for the main deformation phases of the Transantarctic Mountains: new stratigraphic and isotopic constraints from the Pensacola Mountains, Antarctica. Journal of the Geological Society of London 158, 295-308.

Rozanov, A.Yu., Debrenne, E., 1974. Age of Archaeocyathid assemblages. American Journal of Science 274, 833-848.

Rudnick, R.L., 1992. Restites, Eu anomalies, and the lower continental crust. Geochimica et Cosmochimica Acta 56, 963-970.

Rustan, J., Cingolani, C., Cicardi, A., Uriz, N., 2013. Lower Silurian trilobites from the Northern Patagonia Sierra Grande Formation. Ameghiniana 50 (6) Suplemento 2013, Resumen R 68

Sato, A.M., González, P.D., Llambias, E., 2003. Evolución del orógeno Famatiniano en la Sierra de San Luis: magmatismo de arco, deformación y metamorfismo de bajo a alto grado. Revista de la Asociación Geológica Argentina 58 (4), 487-504.

Schilling, M., Carlson, R., Tassara, A., Vieira Conceição, R., Bertotto, W., Vásquez, M., Muñoz, M., Jalowitzki, T., Gervasoni, F., Morata, D., 2017. The origin of Patagonia revealed by Re-Os systematics of mantle xenoliths. Precambrian Research 294, 15-32.

Schmidt, L., Doverj, H., Forda, B., Brown, D., 1964. Geology of the Patuxent Mountains. In: Adie, R.J. (Ed.), Antarctic Geology. North-Holland, Amsterdam, pp. 276-283.

Schmitt, R., Fragoso, R., Collins, A., 2018. Suturing Gondwana in the Cambrian: the orogenic events of the final amalgamation. In: Siegesmund, S., Basei, M., Oyhantçabal, P., Oriolo, S. (Eds.), Geology of Southwest Gondwana. Regional Geology Reviews. Springer, Cham, pp. 411-432.

Serra Varela, S., Giacosa, R., González, P.D., Heredia, N., Martín-González, F., Pedreira, D. 2016. Geología y geocronología del basamento paleozoico de los Andes Norpatagónicos en el área de San Martín de los Andes. $9^{\circ}$ Congreso Geológico de España, Huelva. Geo-Temas vol. 16(2), pp. 431-434.

Shand, S.J., 1927. Eruptive Rocks. Their Genesis, Composition, Classification and Their Relation to Ore Deposits. Murby, London (444 pp.).

Siccardi, A., Uriz, N., Rustán, J., Cingolani, C., 2014. Hirnantian?-Early Silurian brachiopods from the Sierra Grande Formation (North Patagonian Massif, Río Negro Province, Argentina). 4th International Palaeontological Congress, Abstract Volume, Mendoza (807 pp.).

Smedley, P., 1986. The relationship between calc-alkaline volcanism and within-plate continental rift volcanism: evidence from Scottish Palaeozoic lavas. Earth and Planetary Science Letters 77 (1), 113-128.

Sparks, R.S., Huang, T.C., 1980. The volcanological significance of deep-sea ash layers associated with ignimbrites. Geological Magazine 117 (5), 425-436.

Spear, F., 1995. Metamorphic phase equilibria and pressure-temperature-time paths. Mineralogical Society of America, Monograph Series, No. 1 Washington, DC. (799 pp.).

Stewart, A.L., McPhie, J., 2003. Internal structure and emplacement of an Upper Pliocene dacite cryptodome, Milos Island, Greece. Journal of Volcanology and Geothermal Research $124,129-148$

Stone, P., Thomson, M., 2005. Archaeocyathan limestone blocks of likely Antarctic origin in Gondwanan tillite from the Falkland Islands. In: Vaughan, A., Leat, P.. Pankhurst, R. (Eds.), Terrane Processes at the Margins of Gondwana. Geological Society, London, Special Publication vol. 246, pp. 347-357.

Stone, P., Thomson, M., Rushton, A., 2012. An Early Cambrian archaeocyath-trilobite fauna in limestone erratics from the Upper Carboniferous Fitzroy Tillite Formation, Falkland Islands. Earth and Environmental Science Transactions of the Royal Society of Edinburgh 102, 201-225.

Storey, B.C., Macdonald, D.I.M., Dalziel, I.W.D., Isbell, J.L., Millar, I.L., 1996. Early Paleozoic sedimentation, magmatism, and deformation in the Pensacola Mountains, Antarctica: the significance of the Ross orogeny. Geological Society of America Bulletin 108, 685-707.

Stump, E., 1995. The Ross Orogen of the Transantarctic Mountains. Cambridge University Press (284 pp.).

Tang, G., Wang, Q., Wyman, D., Li, Z.-X., Xu, Y.-G., Zhao, Z.-H., 2012. Recycling oceanic crust for continental crustal growth: Sr-Nd-Hf isotope evidence from granitoids in the western Junggar region, NW China. Lithos 128-131, 73-83.
Tohver, E., Cawood, P.A., Rossello, E., López de Luchi, M.G., Rapalini, A., Jourdan, F., 2008 New SHRIMP U-Pb and ${ }^{40} \mathrm{Ar} /{ }^{39} \mathrm{Ar}$ constraints on the crustal stabilization of southern South America, from the margin of the Rio de Plata (Sierra de Ventana) craton to northern Patagonia. American Geophysical Union, Fall Meeting, Abstract T23C2052, San Francisco.

Tohver, E., Cawood, P.A., Rosello, E., Jourdan, F., 2012. Closure of the Clymene Ocean and formation of West Gondwana in the Cambrian: evidence from the Sierras Australes of the southernmost Rio de la Plata craton, Argentina. Gondwana Research 21, 394-405.

Tomita, K., Shiraki, K., Kawano, M., 1998. Crystal structure of dehydroxylated 2M1 sericite and its relationship with mixed-layer mica/smectite. Clay Science 10, 432-441.

Trindade, R.I., D'Agrella-Filho, M.S., Epof, I., Brito Neves, B.B., 2006. Paleomagnetism of Early Cambrian Itabaiana mafic dikes (Brazil) and the final assembly of Gondwana. Earth and Planetary Science Letters 244, 361-377.

Unrug, R., 1997. Rodinia to Gondwana: the geodynamic map of Gondwana Supercontinent Assembly. GSA Today 7 (1), 1-6.

Uriz, N.J., Cingolani, C.A., Chemale Jr., F., Macambira, M.B., Armstrong, R., 2011. Isotopic studies on detrital zircons of Silurian-Devonian siliciclastic sequences from Argentinean North Patagonia and Sierra de la Ventana regions: comparative provenance. International Journal of Earth Sciences 100, 571-589.

Van Schmus, W.R., McKenna, L.W., Gonzales, D.A., Fetter, A.H., Rowell, A.J., 1997. U-Pb geochronology of parts of the Pensacola, Thiel, and Queen Maud Mountains, Antarctica. In: Ricci, C.A. (Ed.), The Antarctic Region: Geological Evolution and Processes. Terra Antarctica Publication, Siena, pp. 187-200.

Varela, R., Cingolani, C., Sato, A., Dalla Salda, L., Brito Neves, B., Basei, M., Siga Jr., O., Texeira, W., 1997. Proterozoic and Paleozoic evolution of Atlantic area of NorthPatagonian Massif, Argentina. 1st South American Symposium on Isotope Geology, San Pablo, Brasil, pp. 326-329.

Varela, R., Basei, M., Sato, A., Siga Jr., O., Cingolani, C., Sato, K., 1998. Edades isotópicas Rb/ $\mathrm{Sr}$ y U/Pb en rocas de Mina Gonzalito y Arroyo Salado. Macizo Norpatagónico Atlántico, Río Negro, Argentina. $10^{\circ}$ Congreso Latinoamericano de Geología 1, pp. 71-76.

Varela, R., Basei, M., Brito Neves, B., Sato, A., Texeira, W., Cingolani, C., Siga Jr., 1999. Isotopic study of igneous and metamorphic rocks of Comallo-Paso Flores, Río Negro, Argentina. 2nd South American Symposium on Isotope Geology, pp. 148-151.

Varela, R., Basei, M., Cingolani, C., Siga, Jr, Passarelli, C., 2005. El basamento cristalino de los Andes norpatagónicos en Argentina: geocronología e interpretación tectónica. Andean Geology 32 (2), 167-187.

Varela, R., Sato, K., González, P.D., Sato, A.M., Basei, M.A., 2007. Descifrando la edad y significado del plutonismo Paleozoico en Sierra Grande, Noreste Patagónico, Argentina. $5^{\circ}$ Congreso Uruguayo de Geología, Abstract 132, Montevideo, Uruguay (1 p.).

Varela, R., Basei, M., González, P., Sato, A., Sato, K., 2008. Granitoides Famatinianos y Gondwánicos en Sierra Grande. Nuevas edades radimétricas método U-Pb. $17^{\circ}$ Congreso Geológico Argentino 2, San Salvador de Jujuy, pp. 914-915.

Varela, R., Sato, K., González, P., Sato, A., Basei, M., 2009. Geología y geocronología Rb-Sr de granitoides de Sierra Grande, Provincia de Río Negro. Revista de la Asociación Geológica Argentina 64 (2), 274-283.

Varela, R., González, P., Basei, M., Sato, K., Sato, A., Naipauer, M., García, V., González, S., Greco, G., 2011. Edad del Complejo Mina Gonzalito: Revisión y nuevos datos. $18^{\circ}$ Congreso Geológico Argentino Abstracts, Neuquén, pp. 127-128 (CD).

Varela, A.N., Gómez Peral, L., Richiano, S., Poiré, D., 2013. Distinguishing similar volcanic source areas from an integrated provenance analysis: implications for foreland Andean basins. Journal of Sedimentary Research 83, 258-276.

Varela, R., González, P.D., Philipp, R., Sato, A.M., González, S.N., Greco, G.A., Naipauer, M., 2014. Isótopos de estroncio en calcáreos del noreste patagónico: resultados preliminares. Revista de la Asociación Geológica Argentina 71, 526-536.

Veevers, J.J., 2004. Gondwanaland from 650-500 Ma assembly through 320 Ma merger in Pangea to 185-100 Ma breakup: supercontinental tectonics via stratigraphy and radiometric dating. Earth-Science Reviews 68 (1-2), 1-132.

Vennum, W.R., Storey, B.C., 1987. Correlation of gabbroic and diabasic rocks from the Ellsworth Mountains, Hart Hills, and Thiel Mountains, West Antarctica. In: McKenzie, G.D. (Ed.), Gondwana Six: Structure, Tectonics, and Geophysics. Amercian Geophysical Union, Geophysical Monograph vol. 40, pp. 129-138.

Vennum, W.R., Gizycki, P., Samsonov, V.V., Markovich, A.G., Pankhurst, R.J., 1992. Igneous petrology and geochemistry of the southern Heritage Range, Ellsworth Mountains, West Antarctica. In: Webers, G.F., Craddock, C., Splettstoesser, J.F. (Eds.), Geology and Paleontology of the Ellsworth Mountains. West Antarctica. Geological Society of America Memoir vol. 170, pp. 295-324.

von Gosen, W., 2002. Polyphase structural evolution in the northeastern segment of the North Patagonian Massif (southern Argentina). Journal of South American Earth Sciences 15, 591-623.

von Gosen, W., 2003. Thrust tectonics in the North Patagonian Massif (Argentina): implications for a Patagonia Plate. Tectonics 22 (1), 1005.

von Gosen, W., 2009. Stages of Late Paleozoic deformation and intrusive activity in the western part of the Northpatagonian Massif (southern Argentina) and their geotectonic implications. Geological Magazine 146 (1), 48-71.

Wareham, C., Stump, E., Storey, B., Millar, I., Riley, T., 2001. Petrogenesis of the Cambrian Liv Group, a bimodal volcanic rock suite from the Ross orogen, Transantarctic Mountains. Geological Society of America Bulletin 113, 360-372.

Weber, E., 1983. Descripción Geológica de la Hoja 40j, Cerro El Fuerte (Provincia de Río Negro). Servicio Geológico Nacional, Boletín N 196, Buenos Aires (69 pp.).

Webers, G.F., Splettstoesser, J.F., 2007. Review of the geology and paleontology of the Ellsworth Mountains, Antarctica. USGS OF-2007-1047, Short Research Paper 107, pp. 1-5.

Webers, G.F., Craddock, C., Splettstoesser, J.F., 1992. Geologic history of the Ellsworth Mountains, West Antarctica. In: Webers, G.F., Craddock, C., Splettstoesser, J.F. (Eds.), 
Geology and paleontology of the Ellsworth Mountains, West Antarctica. Geological Society of America, Memoir vol. 170, pp. 1-8.

Whalen, J.B., Currie, K., Chappell, B., 1987. A-type granites: geochemical characteristics, discrimination, and petrogenesis. Contributions to Mineralogy and Petrology 95 (4), 407-419.

Wilson, B.M., 2007. Igneous Petrogenesis: A Global Tectonic Approach. Springer, The Netherlands (466 pp.).

Winchester, J.A., Floyd, P.A., 1977. Geochemical discrimination of different magma series and their differentiation products using immobile elements. Chemical Geology 20, 325-343.
Wood, D.A., Joron, J.-L., Treuil, M., 1979. A re-appraisal of the use of trace elements to classify and discriminate between magma series erupted in different tectonic settings. Earth and Planetary Science Letters 45, 326-336.

Wood, R., Evans, K., Zhuravleva, A., 1992. A new post-Early Cambrian archaeocyath from Antarctica. Geological Magazine 129, 491-495.

Zanettini, J., 1981. La Formación Sierra Grande (provincia de Río Negro). Revista de la Asociación Geológica Argentina 36 (2), 160-179.

Zanettini, J. 1999. Los depósitos ferríferos de Sierra Grande, Río Negro In: Zappettini, 0. (Ed.), Recursos Minerales de la República Argentina. Instituto de Geología y Recursos Minerales, SEGEMAR, Anales 35, Buenos Aires, pp. 745-762. 